Hall, I.R., Hemming, S.R., LeVay, L.J., and the Expedition 361 Scientists Proceedings of the International Ocean Discovery Program Volume 361 publications.iodp.org

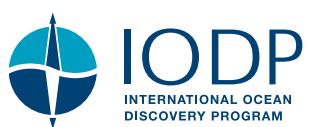

doi:10.14379/iodp.proc.361.101.2017

\title{
Expedition 361 summary ${ }^{1}$
}

I.R. Hall, S.R. Hemming, L.J. LeVay, S. Barker, M.A. Berke, L. Brentegani,

T. Caley, A. Cartagena-Sierra, C.D. Charles, J.J. Coenen, J.G. Crespin,

A.M. Franzese, J. Gruetzner, X. Han, S.K.V. Hines, F.J. Jimenez Espejo, J. Just,

A. Koutsodendris, K. Kubota, N. Lathika, R.D. Norris, T. Periera dos Santos,

R. Robinson, J.M. Rolinson, M.H. Simon, D. Tangunan, J.J.L. van der Lubbe,

M. Yamane, and H. Zhang ${ }^{2}$

Keywords: International Ocean Discovery Program, IODP, JOIDES Resolution, Expedition 361, Site U1474, Site U1475, Site U1476, Site U1477, Site U1478, Site U1479, Agulhas Current, Agulhas leakage, Agulhas Plateau, Agulhas Retroflection, Agulhas Return Current, Agulhas Rings, Agulhas Undercurrent, Atlantic Meridional Overturning Circulation, boundary current, Cape Basin, Circumpolar Deep Water, Congo Air Boundary, Delagoa Bight, East Madagascar Current, human evolution, Indian Ocean, Indonesian Throughflow, interocean exchange, Intertropical Convergence Zone, Last Glacial Maximum, Limpopo River, Middle Pleistocene Transition, Miocene, Mozambique Channel, Natal Valley, North Atlantic Deep Water, ocean circulation, paleoceanography, paleoclimate, Pleistocene, Pliocene, salinity, southern Africa, Southern Ocean, Subantarctic Zone, Subtropical Front, Subtropical Gyre, thermohaline circulation, Warm Water Route, Western Boundary Current, Zambezi River

\section{Abstract}

International Ocean Discovery Program Expedition 361 drilled six sites on the southeast African margin (southwest Indian Ocean) and in the Indian-Atlantic Ocean gateway, from 30 January to 31 March 2016. In total, $5175 \mathrm{~m}$ of core was recovered, with an average recovery of $102 \%$, during 29.7 days of on-site operations. The sites, situated in the Mozambique Channel at locations directly influenced by discharge from the Zambezi and Limpopo River catchments, the Natal Valley, the Agulhas Plateau, and Cape Basin, were targeted to reconstruct the history of the greater Agulhas Current system over the past $\sim 5 \mathrm{My}$. The Agulhas Current is the strongest western boundary current in the Southern Hemisphere, transporting some $70 \mathrm{~Sv}$ of warm, saline surface water from the tropical Indian Ocean along the East African margin to the tip of Africa. Exchanges of heat and moisture with the atmosphere influence southern African climates, including individual weather systems such as extratropical cyclone formation in the region and rainfall patterns. Recent ocean model and paleoceanographic data further point at a potential role of the Agulhas Current in controlling the strength and mode of the Atlantic Meridional Overturning Circulation (AMOC) during the Late Pleistocene. Spillage of saline Agulhas water into the South Atlantic stimulates buoyancy anomalies that may influence basin-wide AMOC, with implications for convective activity in the North Atlantic and global climate change. The main objectives of the expedition were to establish the role of the Agulhas Current in climatic changes during the Pliocene-Pleistocene, specifically to document the dynamics of the Indian-Atlantic Ocean gateway circulation during this time, to examine the connection of the Agulhas leakage and AMOC, and to address the influence of the Agulhas Current on African terrestrial climates and coincidences with human evolution. Additionally, the expedition set out to fulfill the needs of Ancillary Project Letter number 845, consisting of high-resolution interstitial water sampling to help constrain the temperature and salinity profiles of the ocean during the Last Glacial Maximum.

The expedition made major strides toward fulfilling each of these objectives. The recovered sequences allowed generation of complete spliced stratigraphic sections that range from 0 to between $\sim 0.13$ and $7 \mathrm{Ma}$. This sediment will provide decadal- to millennial-scale climatic records that will allow answering the paleoceanographic and paleoclimatic questions set out in the drilling proposal.

\section{Introduction}

The Agulhas Current is a fundamental component of the South Indian Ocean subtropical gyre circulation and constitutes the stron-

\footnotetext{
${ }^{1}$ Hall, I.R., Hemming, S.R., LeVay, L.J., Barker, S., Berke, M.A., Brentegani, L., Caley, T., Cartagena-Sierra, A., Charles, C.D., Coenen, J.J., Crespin, J.G., Franzese, A.M., Gruetzner, J., Han, X., Hines, S.K.V., Jimenez Espejo, F.J., Just, J., Koutsodendris, A., Kubota, K., Lathika, N., Norris, R.D., Periera dos Santos, T., Robinson, R., Rolinson, J.M., Simon, M.H., Tangunan, D., van der Lubbe, J.J.L., Yamane, M., and Zhang, H., 2017. Expedition 361 summary. In Hall, I.R., Hemming, S.R., LeVay, L.J., and the Expedition 361 Scientists, South African Climates (Agulhas LGM Density Profile). Proceedings of the International Ocean Discovery Program, 361: College Station, TX (International Ocean Discovery Program). http://dx.doi.org/10.14379/iodp.proc.361.101.2017

2 Expedition 361 Scientists' addresses.

MS 361-101: Published 30 September 2017

This work is distributed under the Creative Commons Attribution 4.0 International (CC BY 4.0) license. (c))BY
} 
Figure F1. Global composite of land surface reflectance and sea-surface temperature (credit: Jacques Descloitres, MODIS Land Science Team, NASA) with schematic representation of the greater Agulhas Current system and its links to the Atlantic Meridional Overturning Circulation. The greater Agulhas Current system around South Africa consists of the Agulhas Current flowing south along the African shelf. Off the southern tip of Africa, the Agulhas Current abruptly retroflects and feeds back into the Indian Ocean. During this process, huge rings of water (Agulhas rings) are separated, drifting into the Atlantic and representing "salt leakage."

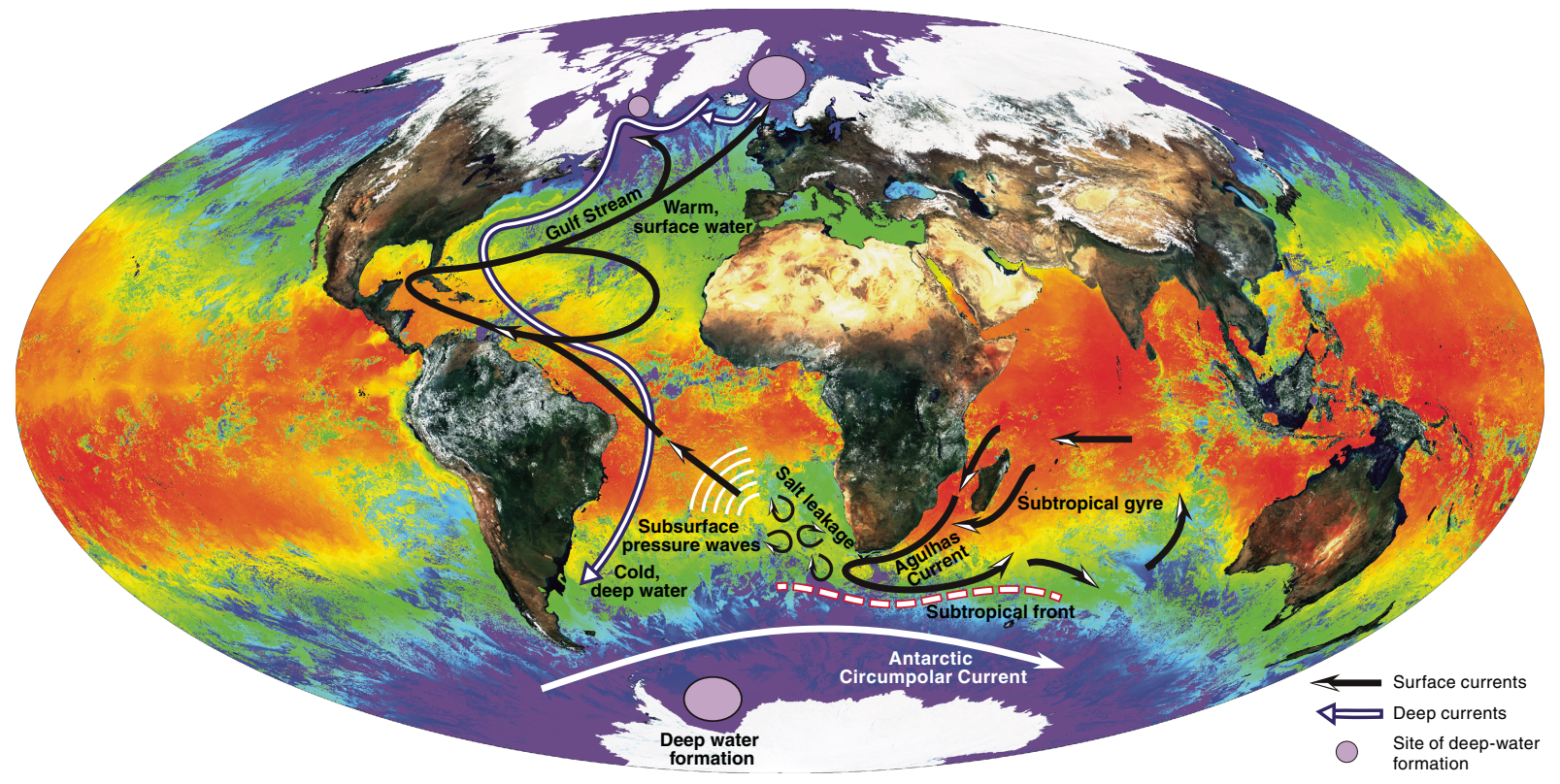

Figure F2. Surface currents of the greater Agulhas Current system represented in a high-resolution ocean model (snapshot). Upstream of the Agulhas Current, eddies around Madagascar lead to short-term offshore meanders of the main current by several hundred kilometers. Credit: Professor Dr. Arne Biastoch, GEOMAR Helmholtz Centre for Ocean Research Kiel, Germany.

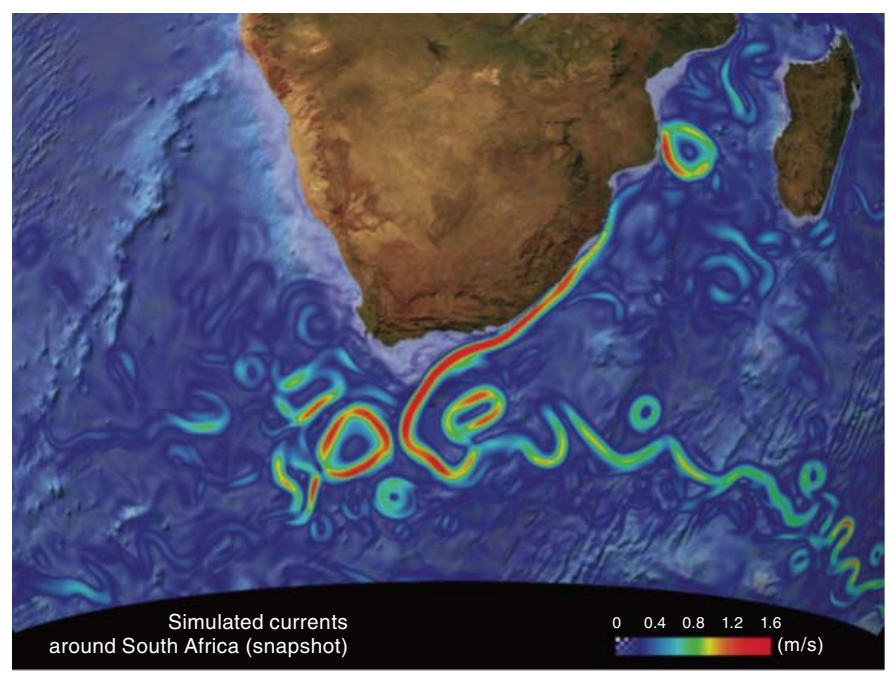

gest western boundary current in the Southern Hemisphere (Lutjeharms, 2006a) transporting $\sim 70 \mathrm{~Sv}\left(1 \mathrm{~Sv}=10^{6} \mathrm{~m}^{3} / \mathrm{s}\right)$ of warm, saline tropical surface waters to the tip of Africa (Figures F1, F2), roughly twice that of the Gulf Steam in the North Atlantic (Cunningham et al., 2007). Like its northern counterpart, the Agulhas Current fosters exchanges of heat and moisture with the atmosphere that influence regional climates and weather systems (Reason and Mulenga, 1999). A portion of the Agulhas waters invade the South Atlantic through the Agulhas rings (Arhan et al., 2011), which form when the current retroflects at the tip of Africa and transport between 5 and $20 \mathrm{~Sv}$ of warm, saline water from the Indian Ocean to the South Atlantic-the so-called interocean "warm-water route" of the global oceanic thermohaline circulation (THC). Ocean models and paleoceanographic data strongly suggest that the "leakage" of saline Agulhas water into the South Atlantic stimulates regional buoyancy anomalies that ultimately impact convective activity in the northern North Atlantic, plausibly acting as a contributor to the basin-wide Atlantic Meridional Overturning Circulation (AMOC) (Figure F1) (Weijer, 2001; Weijer et al., 2002; Knorr and Lohmann, 2003; van Sebille et al., 2009; Biastoch et al., 2008, 2009a). Numerical simulations specifically point to Agulhas leakage as a potential modulator of the AMOC and a rheostat for the ventilation of the deep ocean. Hence the significance of the Agulhas Current is threefold: (1) the Agulhas Current is a significant component of the global THC-carrying surface water into the Atlantic that compensates for the export of deep water from the Atlantic Basin to the world ocean, (2) the Agulhas leakage transfer of salt to the South Atlantic variably impacts the buoyancy structure there and may contribute to mode changes and variability of the AMOC and thus climate variability in the North Atlantic region and beyond, and (3) variations in Agulhas warm-water transports along the southeast African continental margin drive interannual variability with implications for southern Africa regional climate and weather systems.

Studies of the long-term evolution of ocean circulation off southern Africa, on Pliocene-Pleistocene timescales, have previously been undertaken on the Atlantic side of the continent. Deep Sea Drilling Project (DSDP) Legs 40 and 75 in 1974 and 1980 and Ocean Drilling Program (ODP) Legs 108 and 114 in 1985 and 1987 targeted the southwest African continental slope and rise north and south of Walvis Ridge to explore marine conditions during the opening of the South Atlantic, including the origin and paleoceanographic history of the Eastern Walvis Ridge and carbonate dissolution cycles. More recently, ODP Leg 175 in 1997 targeted the 
southeastern Atlantic margin between $5^{\circ}$ and $32^{\circ} \mathrm{S}$ to assess the history of the Benguela Current and upwelling off Angola and Namibia. ODP Leg 208 in 2003 drilled a transect of six sites on Walvis Ridge to gain insight into paleoceanographic events such as the hyperthermal events of the Paleocene and Eocene and the early Oligocene Oi1 cold event.

By contrast, the eastern continental margin off southern Africa is poorly represented in the database of scientific drill sites. Prior to Expedition 361, only one site, DSDP Site 244, had been drilled within the direct reaches of the South Indian Ocean western boundary current. The site is positioned on Davie Ridge, at the northern entrance of the Mozambique Channel, and was occupied during Leg 25 in 1972 (Simpson, Schlich, et al., 1974) to provide data on the structure and geological history of the East African margin and western Madagascar.

Expedition 361 fills this scientific/geographic gap by drilling targets in three sectors of the greater Agulhas Current system (Figure F3):

1. The northern sector in the Mozambique Channel that provides the source waters of the Agulhas Current,

2. The central sector in the confluence region where the southwestern extension of the East Madagascar Current converges

Figure F3. Expedition 361 site locations. Also shown is a schematic representation of the main surface ocean currents (yellow and orange arrows) in the southwest Indian Ocean and atmospheric circulation over southern Africa during austral summer (December-February) with approximate position of the Intertropical Convergence Zone (ITCZ) and the Congo Air Boundary (CAB) (dashed lines; adapted from Reason et al., 2006). AC = Agulhas Current, SEC = South Equatorial Current, SEMC = South East Madagascar Current, NEMC = North East Madagascar Current, EACC = East Africa Coastal Current, $M C=$ Madagascar Current, $A R C=$ Agulhas Return Current, $\mathrm{AL}=$ Agulhas leakage, TB = Transkei Basin. Purple shaded area = Zambezi Catchment, green shaded area = Limpopo Catchments. Gray arrows = main pathways of moisture supply to the African continent from the northwest Atlantic (via Congo) and the northwest and southwest Indian Ocean.

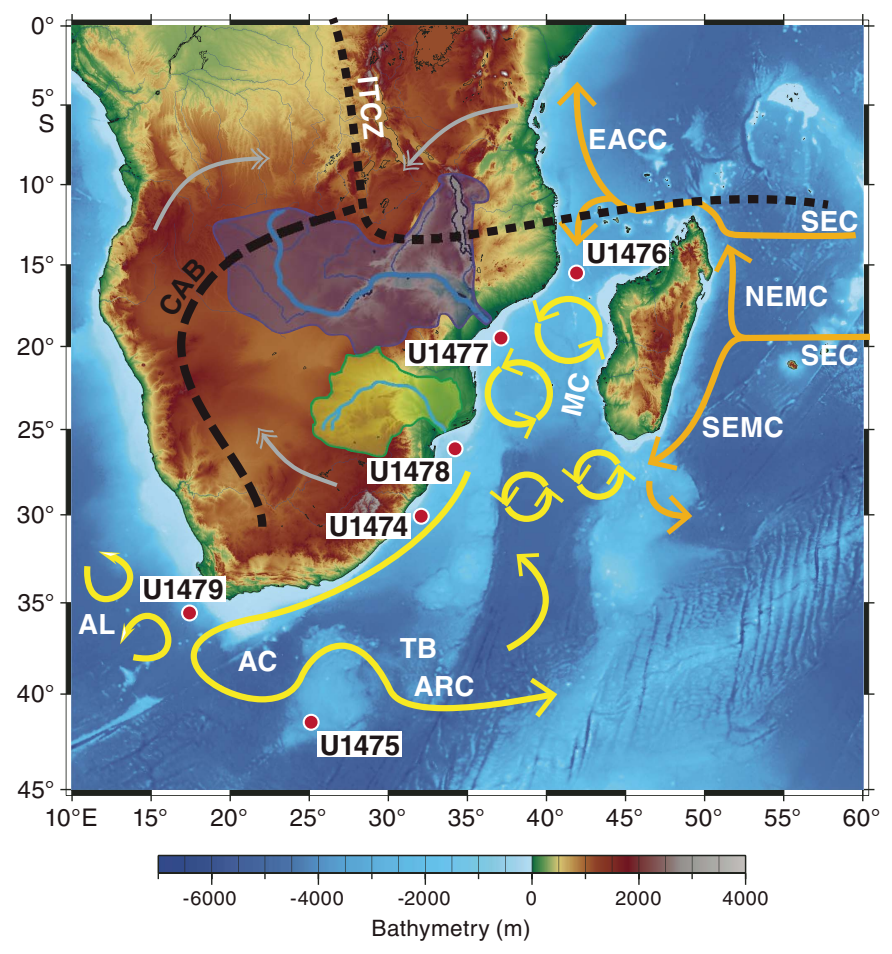

with the Mozambique Channel throughflow to form the Agulhas Current, and

3. The southern sector in the Indian-Atlantic Ocean gateway at the tip of Africa with Agulhas retroflection, Agulhas Return Current (ARC), and Agulhas leakage.

Analysis of the sediments from Expedition 361 will help to address the scientific objectives outlined below.

\section{Background Motivation for drilling in the greater
Agulhas Current system \\ The Agulhas Current system-modern oceanographic circulation}

The Agulhas Current constitutes the largest ocean western boundary jet in the Southern Hemisphere. The current is part of the warm-water return flow that feeds the renewal of North Atlantic Deep Water (NADW) and is a key component of the global oceanic thermohaline "conveyor belt" circulation (Gordon, 1986; Weijer et al., 1999; Lutjeharms, 2006a). The Agulhas Current carries thermocline waters from the South Indian Ocean subtropical gyre with contributions from the Red Sea and Arabian Sea and from the Indonesian Throughflow (Lutjeharms, 2006a) (Figure F4). Driven by the anticyclonic wind field over the South Indian Ocean, Agulhas Current water is advected by eddies and meanders from the equatorial Indian Ocean through the Mozambique Channel and the East Madagascar Current (EMC) (Song et al., 2004; Beal et al., 2006). Interaction between Madagascar and westward-traveling Rossby waves from the tropical Indian Ocean contribute to the formation of eddies (Schouten et al., 2002a) east of Madagascar (Biastoch and Krauss, 1999). Four to five of these eddies per year, as wide as 350 $\mathrm{km}$, drift southward through the Mozambique Channel, with a mean transport of $17 \mathrm{~Sv}$ (Ridderinkhof et al., 2010). These eddies impose short-term circulation modulation over the entire depth and width of the channel (de Ruijter et al., 2002) and impart an interannual variability of $\sim 9 \mathrm{~Sv}$ to the Agulhas Current (Biastoch et al., 2009a).

The ocean/atmosphere coupling in the tropical Indian Ocean provides important upstream forcing of the Agulhas Current (Ridderinkhof et al., 2010). The South Equatorial Current (SEC), splits into a southern and northern branch, once reaching Madagascar, forming the South East Madagascar Current (SEMC) and North East Madagascar Current (NEMC) (Figure F3). The SEMC has an estimated average transport of $20 \mathrm{~Sv}$ in its northern reaches (Donohue and Toole, 2003; Schott et al., 1988), increasing to $35 \mathrm{~Sv}$ at the southern tip of Madagascar (Nauw et al., 2008). At the latitude of Durban $\left(30^{\circ} \mathrm{S}\right)$, the westward-flowing southern extension of the SEMC converges with the southward-flowing train of Mozambique Channel eddies to form the Agulhas Current as a narrow jet-type current that is steered by the steep South African continental margin. Fully constituted at $32^{\circ} \mathrm{S}$, the Agulhas Current carries $\sim 70 \mathrm{~Sv}$ of warm $\left(24^{\circ}-17^{\circ} \mathrm{C}\right)$ and saline $(35.5-35.2 \mathrm{psu})$ (Gordon and Haxby, 1990; Gordon et al., 1992; Beal and Bryden, 1999; Bryden and Beal, 2001) waters of the South Indian Ocean thermocline (Bryden et al., 2005). In its deeper parts, the current also includes saline Red Sea Intermediate Water (Gordon et al., 1987) and other waters derived from far-distant sources in the Pacific Ocean (Gordon and Fine, 1996; Speich et al., 2002) (Figure F4).

The Agulhas Current's mean trajectory is steered by the bathymetry of the narrow southeast African shelf where its steep conti- 
Figure F4. Potential temperature vs. salinity for the western Indian Ocean (adapted from Gordon et al., 1987). SICW = South Indian Central Water, SAMW $=$ Subantarctic Mode Water, NADW $=$ North Atlantic Deep Water, AABW = Antarctic Bottom Water, AAIW = Antarctic Intermediate Water, AASW = Antarctic Surface Water, SAASW = Subantarctic Surface Water.

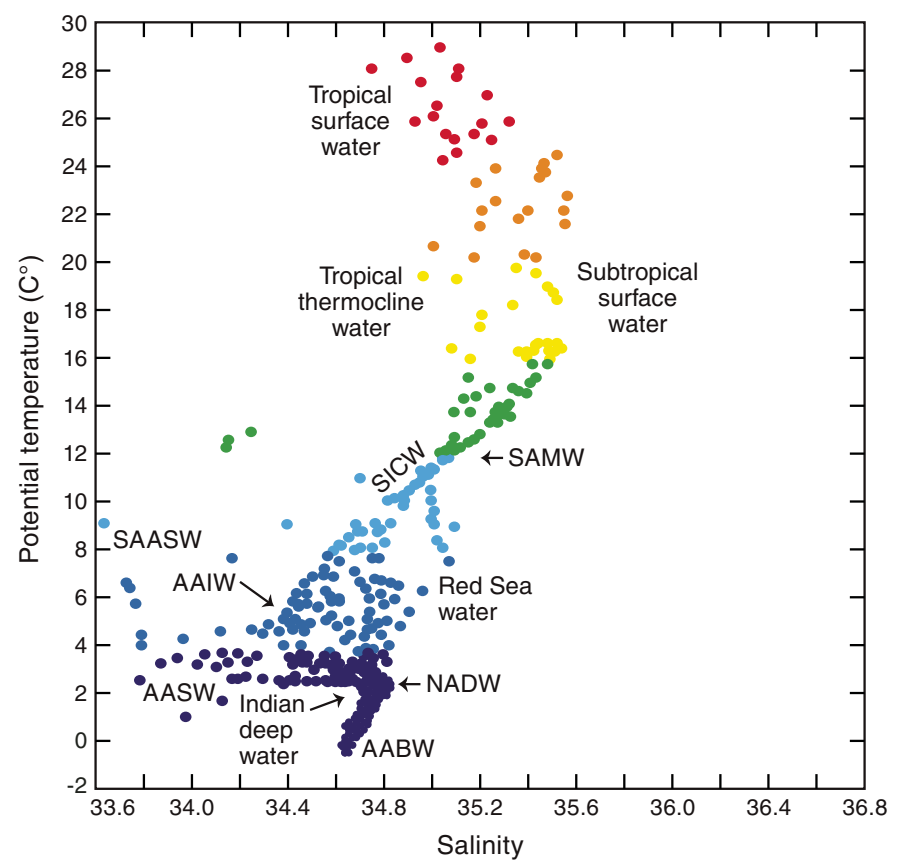

nental slope provides for maximum barotropic and baroclinic guidance (de Ruijter et al., 1999b; Lutjeharms and de Ruijter, 1996; Goschen and Schuman, 1990). Instabilities of the current are caused by the migration of eddies and meanders that interact with the bathymetry and morphology of the continental margin. An example is solitary meanders that form in the Natal Bight, the so-called Natal Pulses (Figure F5) (e.g., Lutjeharms and Roberts, 1988; Beal and Bryden, 1999; de Ruijter et al., 1999b; van Leeuwen et al., 2000; Bryden et al., 2005; Biastoch et al., 2008; Tsugawa and Hasumi, 2010; Rouault and Penven, 2011). At the tip of Africa, the current veers briefly to the west, driven by its own inertia, and then retroflects back to the east into the Indian Ocean as the ARC (Lutjeharms and Van Ballegooyen, 1988). Mozambique Channel and EMC eddies that propagate downstream with the Agulhas Current as strongly barotropic solitary meanders (Bryden et al., 2005; Biastoch et al., 2009a; Tsugawa and Hasumi, 2010) destabilize the retroflection. Four to six anticyclonic eddies (Agulhas rings) form per year with a radius of up to $400 \mathrm{~km}$; they spin off the retroflection area carrying between 2 and $20 \mathrm{~Sv}$ of thermocline water to the South Atlantic Ocean (de Ruijter et al., 1999a; Richardson, 2007). Some researchers have suggested that Agulhas leakage is linked with interannual modes of Indian and Pacific Ocean variability, thus implying a connection with the Indian Ocean Dipole and Pacific Ocean La Niña/El Niño phases (Schouten et al., 2002b; Palastanga et al., 2006).

\section{Agulhas leakage and the AMOC}

The dynamics of the Agulhas leakage and its possible impact on the AMOC and global climate have been explored in a number of ocean and climate models. These studies suggest that (1) the transfer affects the buoyancy of Atlantic Ocean thermocline waters, potentially influencing NADW formation on multidecadal timescales
Figure F5. Representative SST map overlaid with geostrophic current vectors from daily Odyssea SST analysis provided by the CERSAT and the Ssalto/Duacs absolute geostrophic velocities satellite products. Flow speeds $<30 \mathrm{~cm} / \mathrm{s}$ were not plotted. The loop or meander in the current shows a welldeveloped Natal Pulse just north of Algoa Bay. Image courtesy of Marjolaine Krug (CSIR-NRE).

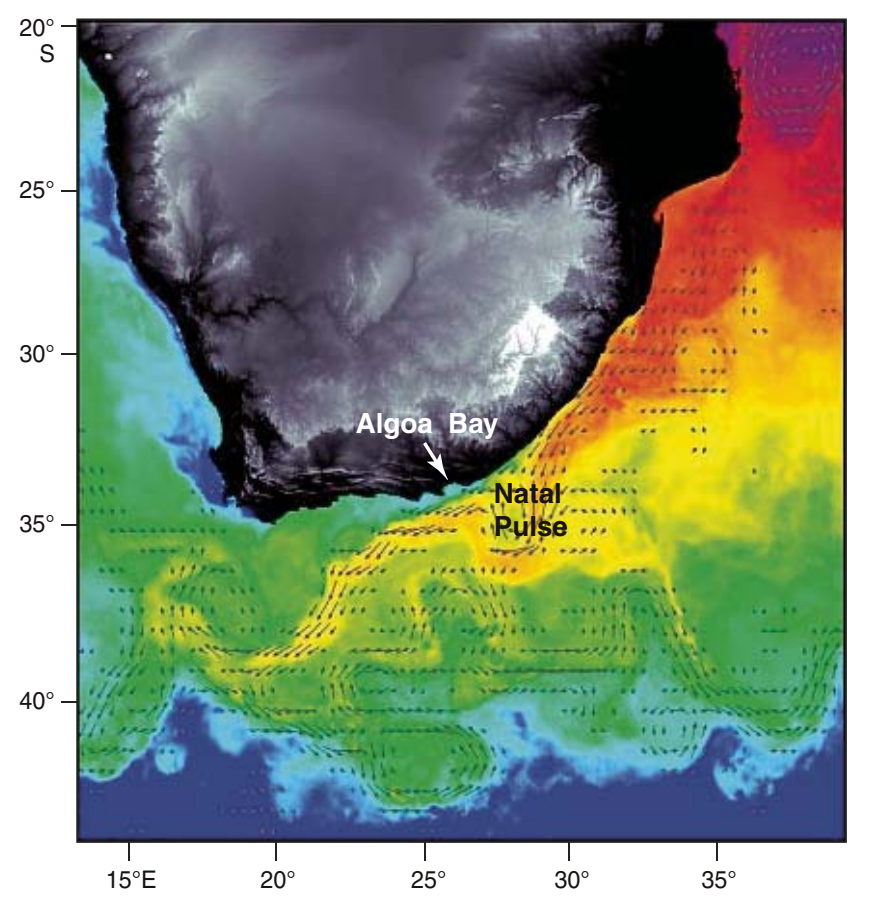

(Weijer et al., 2002; Knorr and Lohmann, 2003; Biastoch et al., 2009a) and (2) perturbations of planetary (Kelvin and Rossby) waves by mesoscale eddies propagate across the Atlantic Basin influence variability of the AMOC (van Sebille and van Leeuwen, 2007; Biastoch et al., 2008, 2009a).

Short-term variability that appears to be associated with Agulhas leakage is observed in the subtropical North Atlantic Ocean (de Ruijter et al., 1999a), whereas some of the interannual to decadal AMOC variability seen in the models plausibly stems from the frequency of Agulhas ring shedding that, in turn, is modulated by tropical interannual variability (de Ruijter et al., 1999a; Gordon and Haxby, 1990). The basin-scale radiation of planetary waves triggered by Agulhas leakage hence constitutes a "fast-response" mechanism that operates on interannual to decadal timescales.

The advection of saltwater from the Agulhas region to the convection centers in the North Atlantic Ocean is the likely connection between the AMOC response and Agulhas leakage. Seeding numerical Lagrangian floats into the Agulhas retroflection area in highresolution ocean general circulation models reveals an advective transit time of 30-40 y from the Agulhas Current to the North Atlantic Ocean (van Sebille et al., 2010). These time estimates are also consistent with those obtained with lower-resolution models (Weijer, 2001). Continuing heat exchange with the overlying atmosphere augments the density anomaly associated with leaked Agulhas saltwater parcels as they drift northward (Weijer, 2001; Haarsma et al., 2011). Agulhas leakage therefore stimulates an AMOC response with a time delay dictated by the advective timescale for the excess salt to reach the North Atlantic Ocean; the new AMOC equilibrium state is achieved several hundred years later when buoyancy fluxes and mixing are in balance (Weijer, 2001; Hughes et al., 2009). Estab- 
lishing the impact of wind forcing on Agulhas leakage and its subsequent effect on the AMOC is not straightforward because the strength and position of the Southern Hemisphere mid-latitude westerlies may affect the Agulhas leakage and AMOC simultaneously (Biastoch et al., 2009b; Toggweiler and Samuels, 1995; Sijp and England, 2008), perhaps by shifting the position of the Subtropical Front (STF) south of Africa. For example, the STF is thought by some to define the width of the Agulhas leakage corridor, hence the strength of the leakage. On the other hand, recent modeling studies show a stronger dynamic relationship with the intensity of the Southern Hemisphere westerlies (Durgadoo et al., 2013). Nonetheless, the westerlies control the northward Ekman transport in the Southern Ocean, which forces deep water to ascend to the upper ocean, conceivably "pulling" the deep branch of the AMOC (Toggweiler and Samuels, 1995; Visbeck, 2007). Through their influence on deep-water upwelling and AMOC strength, the westerly winds and Agulhas buoyancy fluxes likely play important roles in the regulation of the ocean's ability to store carbon (Watson and Garabato, 2006; Backeberg et al., 2012). This connection represents an additional plausible link between Agulhas leakage and global climate variability.

\section{Paleoceanography of the Agulhas Current system}

The Agulhas Current region is an area in which retrieval of high-quality sediment cores is difficult. The southeast African margin has a very narrow shelf and a steep continental slope, leading to frequent sediment instability and slumping. Further, the vigorous Agulhas Current and its mesoscale variability can cause sediment redistribution because meanders and eddies frequently reach the seafloor. Yet, a number of published studies and emerging work demonstrate that paleoceanographic records of excellent quality are in fact achievable for reconstructing both surface and deep-water variability in the region. A full synthesis of the paleoceanographic evidence is yet to emerge, but several aspects of the Agulhas paleotime series reflect broad consensus. Based on published records, Agulhas leakage has been a persistent feature of the past $1.3 \mathrm{My}$, with less leakage during full glacial times than interglacial times and greatest leakage at the glacial terminations (Peeters et al., 2004; Caley et al., 2012; Petrick et al., 2015). There is also general agreement about evidence for a more northerly position of the STF during glacial times (Rau et al., 2002, 2006; Bard and Rickaby, 2009; MartínezMéndez et al., 2010) and some suggestion that this may play a role in reducing Agulhas leakage. However, it is also possible that the positions of the westerly wind belt and STF can be decoupled (Graham and De Boer, 2013; De Boer et al., 2013; Durgadoo et al., 2013), leading to some uncertainty in the exact mechanisms of changing Agulhas leakage.

At the tip of Africa, a spliced record composed of Cores GeoB3603-2 and MD96-2081 (termed the Cape Basin Record; Peeters et al., 2004) shows maximum abundance of the so-called "Agulhas leakage fauna" (ALF) that appears to be related to minima in precession index (maxima in northern summer insolation), leading these authors to suggest a possible teleconnection to the monsoon system. Multiple-proxy data from planktonic foraminifers from sediment Core MD96-2080 on the Agulhas Bank provide a detailed reconstruction of surface-ocean conditions in the area. Continued warming across full-glacial stages (marine isotope Stages [MIS] 2 and 6) displayed in planktonic $\mathrm{Mg} / \mathrm{Ca}$ data implies increased influence of warm Agulhas water in the region and/or reduced northward advection of cold subantarctic surface water (MartínezMéndez et al., 2010) (Figure F6). This pattern is consistent with the
Figure F6. Palaeoceanographic records from sediment Core MD96-2080 (close to Site U1479). A. Planktonic $\delta^{18} \mathrm{O}$ showing glacial-interglacial climates. B. Distribution of ALF from the Cape Basin records from Peeters et al. (2006). C. SST variation along Core MD96-2080 from planktonic $\mathrm{Mg} / \mathrm{Ca}$ ratios. Insert displays ALF section from the same core at the Stage 6-5 transition. D. Sea-surface salinity (SSS) estimated from paleothermometry combining data from A and C. Data from Peeters et al. (2004) and MartínezMéndez et al. (2010).

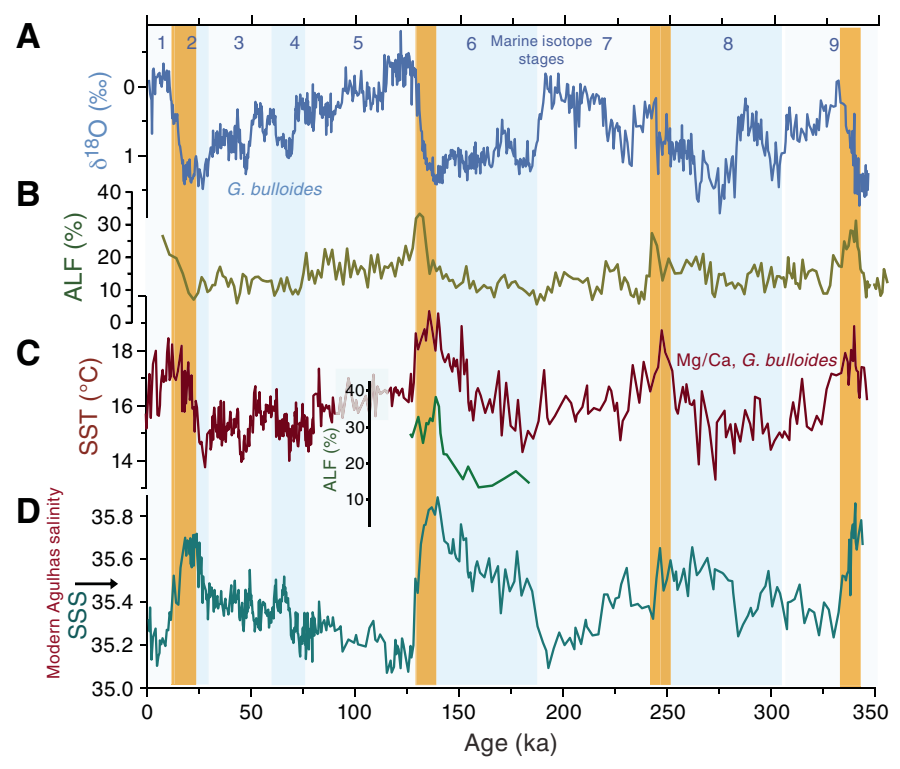

hypothesis that peak Agulhas leakage occurred during glacial terminations and plausibly aided the AMOC to shift to its full-strength interglacial mode (Knorr and Lohmann, 2003, 2007; Peeters et al., 2004). A high-resolution faunal record of the accumulation rate of tropical species Globorotalia menardii at ODP Site 1087 in the southern Benguela region was used to infer that Agulhas leakage strengthened during every glacial termination of the past $1.3 \mathrm{My}$ (Caley et al., 2012). The interpretation of increased leakage during terminations in the Late Pleistocene is also supported by the combination of alkenone proxies $\left(\mathrm{U}_{\mathrm{k}^{\prime}}{ }^{37}\right.$ and $\left.\delta \mathrm{D}\right)$ along with dinoflagellate cyst assemblages, sea-surface temperature (SST), and salinity estimates (Petrick et al., 2015).

SST and salinity records upstream along the southeast African margin (Core MD96-2048; 26 $\mathrm{S}$ ) display prominent 41 ky cyclicity that was interpreted to suggest that long-term Agulhas Current variations are associated with high-latitude (as opposed to regional tropical) climate forcing (Caley et al., 2011). However, the cyclicity also suggests that some of the apparent variability in Agulhas leakage could actually be due to changes in the Agulhas Current. Thus, to circumvent the potential problem that ALF (Peeters et al., 2004) and G. menardii (Rau et al., 2006; Caley et al., 2012) indexes might be sensitive to the changing composition of the Agulhas source assemblage upstream, Caley et al. (2014) developed a new quantitative foraminiferal-based proxy index for Agulhas leakage, named Agulhas leakage efficiency; they suggested that Agulhas leakage efficiency represents the transfer of Agulhas water from the Indian Ocean to the Atlantic Ocean independent of the variations in the source assemblage. Using this approach, Caley et al. (2014) confirmed substantial changes in Agulhas leakage volume transports at the termination of glacial periods and suggested the possibility of a complete halt of leakage during MIS 12. 
The composition of terrigenous sediment in core tops of marine sediment cores around South Africa shows significant and systematic provenance variations (Franzese et al., 2006, 2009). Provenance studies using ${ }^{87} \mathrm{Sr} /{ }^{86} \mathrm{Sr}, \varepsilon \mathrm{Nd}$, and ${ }^{230} \mathrm{Th}_{\mathrm{xs}}$ flux estimates from Holocene and Last Glacial Maximum (LGM) samples from a number of cores near the tip of South Africa were used to suggest reduced advection of sediment derived from Agulhas water (and therefore possibly Agulhas leakage) during peak glacial times (Franzese et al., 2006). In a follow-up study, Franzese et al. (2009) made a more detailed geographic study of Holocene and LGM samples from a set of cores from the R/V Charles Darwin 154 site survey cruise as well as additional Lamont Doherty Earth Observatory repository cores from the Agulhas Plateau. The authors of these two studies infer a weaker Agulhas Current and less leakage, as well as an Agulhas trajectory very similar to modern. These results are partly at odds with models that suggest that if the wind pattern is fixed but its strength reduced, a weaker Agulhas Current results in increased leakage (De Ruijter, 1982; Dijkstra and De Ruijter, 2001; van Sebille et al., 2009). However, if the winds shift northward and weaken during glacial periods, a weaker Agulhas Current could combine with reduced leakage. The equivocal comparison between data and models calls for further work including multiproxy analyses.

A key question concerning Agulhas leakage is How important are the locations of the STF and westerly wind belts? For instance, early work from Core MD96-2080 from the western flank of the Agulhas Bank (Rau et al., 2006) showed the continuous presence of subtropical planktonic foraminifers (e.g., G. menardii); this observation implies persistent leakage of Indian Ocean to Atlantic Ocean surface water flow during the last $450 \mathrm{ky}$. On the other hand, transient occurrences of subpolar species (Neogloboquadrina pachyderma dextral) suggest intermittent incursions of cold subantarctic waters in the Agulhas corridor during glacial periods (Rau et al., 2002, 2006), perhaps the result of meridional shifts of the subtropical and subantarctic fronts. The evidence suggesting significant northward movement of the STF during some full-glacial stages (by as much as $7^{\circ}$; Bard and Rickaby, 2009) is consistent with this idea because Agulhas Current transports into the gateway and leakage to the South Atlantic Ocean would presumably be reduced as a consequence. However, this picture is contrasted by substantial increases of ALF (Peeters et al., 2004) in the Agulhas corridor at the termination of glacial periods, alluding to an involvement of Agulhas leakage in interhemispheric ocean and climate change, notably the resumption of NADW formation (Peeters et al., 2004). Additionally, the records of Caley et al. (2014) and Petrick et al. (2015) also demonstrate Agulhas leakage was a persistent feature of the past $500 \mathrm{ky}$, including glacial MIS 10 (Caley et al., 2014), apparently at odds with the inferred effect on Agulhas leakage caused by the significant northward migration of the STF. Again the apparent contradictions of different data sets and between data sets and theory call for further work.

Multiple-species stable isotope and alkenone data from ODP Site 1085, slightly further north on the Atlantic margin, have also been taken to suggest that Agulhas leakage variability during MIS 11 was directly related to AMOC activity and wind forcing. Site 1085 shows evidence for strengthened leakage at the end of MIS 11 that may have contributed to renewed ice-sheet build-up and the demise of warm conditions (Dickson et al., 2010).

Recent reconstructions detailing the multicentennial- to millennial-timescale hydrographic variability in the Agulhas corridor have been published for the last glacial cycle ( $80 \mathrm{ka}$ to present; Core MD02-2594) (Dyez et al., 2014), the previous two glacial-intergla- cial climate cycles of MIS 8-5 (Core MD96-2080; 265-77 ka) (Marino et al., 2013), and upstream in the Agulhas Current for the last glacial cycle (Core CD154 17-17K; Simon et al., 2013). These studies confirm a connection of leakage maxima with glacial-interglacial climate transitions and extend the connections to millennial-scale salinity anomalies that appear to systematically coincide with accelerated warming at the end of the North Atlantic cold phases (stadials). These findings lend credence to earlier hypothetical considerations (Lutjeharms, 2006a) and numerical models (Knorr and Lohmann, 2003; Weijer et al., 2002; Biastoch et al., 2008) pointing to Indian-Atlantic salt leakage as an essential modulator of abrupt climate change. However, reanalyses of a freshwater LGM hosing experiment using a fully coupled atmosphere-ocean general circulation model (Gong et al., 2013) has been recently used to suggest that the millennial-scale salinity increases in the Agulhas corridor are consistent with the presence of a quasi-interhemispheric salt seesaw. This salt seesaw is analogous to the thermal bipolar seesaw, responding to reduced cross-hemispheric heat and salt exchange during times of weakened AMOC (Simon et al., 2015a). Indeed, Simon et al. (2015a) suggest that although more upstream saline Agulhas water was propagated to the Indian-Atlantic Ocean gateway during Heinrich Stadial 1, the salt flux into the South Atlantic Ocean, through the Indian-Atlantic Ocean gateway, during that time was actually reduced. Accordingly, intervals with higher salinity in the Agulhas Current source region cannot necessarily be taken to indicate increased salt exchange through the Indian-Atlantic Ocean gateway into the South Atlantic Ocean, again calling for further study.

The combined analysis of these multiple proxies on the same sediments from Expedition 361 and the greater time interval available for study will help to elucidate the apparently contradictory scenarios from individual studies.

\section{Agulhas Current links with southern African climates and rainfall patterns}

Southern Africa spans a significant range of climatic and vegetation zones (Figure F7) from the low-latitude tropical regime that is primarily under the influence of the Intertropical Convergence Zone (ITCZ) and Congo Air Boundary (CAB) to the high southern latitudes that are influenced by the northern extensions of the circum-Antarctic westerly wind belt (Tyson, 1986; Chase and Meadows, 2007) (Figure F3). The ITCZ and CAB collectively form the divide between easterly winds arriving from the Indian Ocean and westerly winds from the Atlantic Ocean (Leroux, 1983). Presently, the southernmost extent of the seasonal migrations of the ITCZ and $\mathrm{CAB}$ is situated over the Zambezi Catchment during austral summer (December, January, and February [DJF]). The Zambezi Catchment is the largest riverine catchment in southeastern Africa, with headwaters extending far into the continental interior. Because of the northern position of the African rainfall belt as well as the presence of mountain ranges of the East African Rift zone, annual rainfall amounts are higher across the Zambezi Catchment compared to the neighboring Limpopo Catchment to the south. Although directly connected with the ITCZ, the convergence zone over tropical southern Africa is decoupled on occasion from the divide between dry trade winds in the east and wet monsoon in the west, as occurring, for instance, over West Africa in summer. Rainfall intensity today in southeast Africa is correlated to SST variability in the southwest Indian Ocean and the Agulhas Current system (Reason and Mulenga, 1999; Walker, 1990; Jury et al., 1993; Reason, 2002; Singleton and Reason, 2007). Additionally, the interannual variabil- 
Figure F7. Global land cover map of Africa (Mayaux et al., 2004).

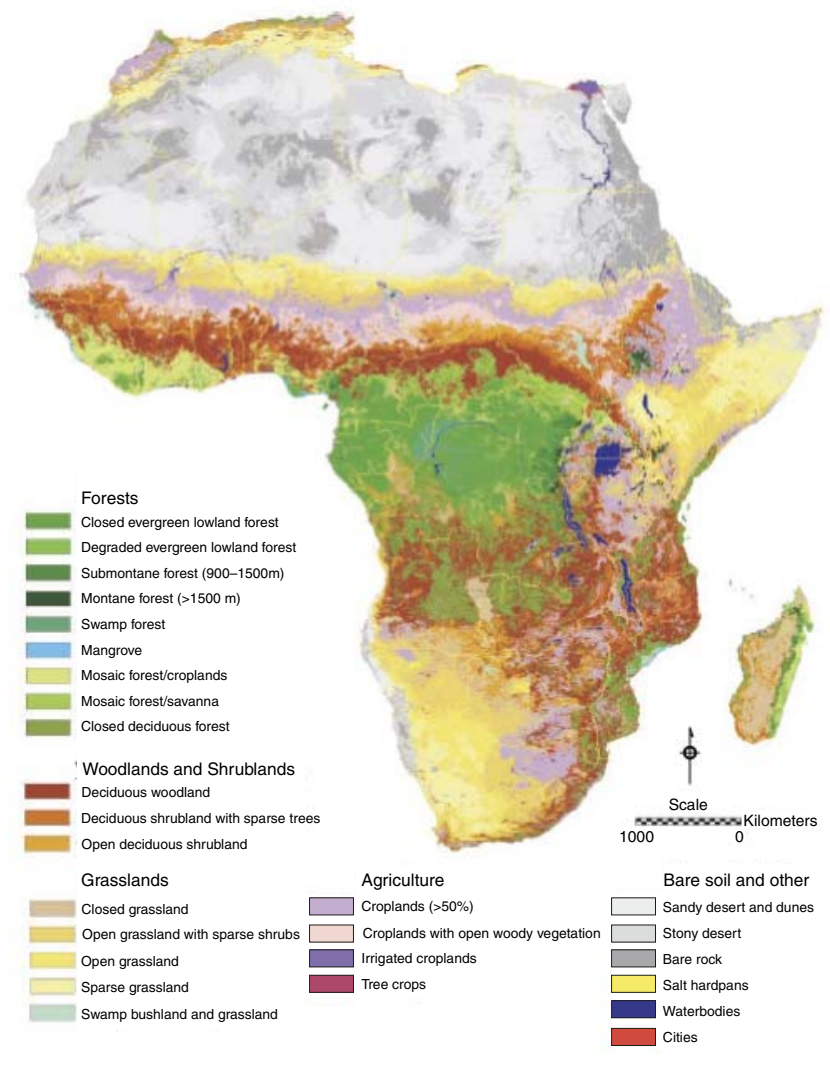

ity of precipitation in the historical record of South Africa is antiphased with that of tropical East Africa (Goddard and Graham, 1999). It is apparent from modern observations that terrestrial precipitation records have very regional patterns, and thus understanding past variability requires records from a range of archives that span this variability.

During the Late Pleistocene, shifts in African climate were paced by regional insolation changes driven by orbital precession (deMenocal et al., 1993). These orbital changes resulted in antiphased summer insolation maxima between the Northern and Southern Hemispheres, driving an interhemispheric temperature contrast resulting in shifts of the ITCZ and leaving an imprint of the summer monsoonal rainfall (Kutzbach et al., 2008). Additionally, African climate was influenced by high-latitude forcing predominantly varying on longer obliquity and eccentricity timescales (Tuenter et al., 2003; Weber and Tuenter, 2011). Although in the lowlatitude tropics African climate is dominated by the influence of the ITCZ and associated rain belts, studies from central and eastern Africa document the increasing influence of the Atlantic and Indian Oceans (Castañeda et al., 2007; Schefuß et al., 2005; Tierney et al., 2008). Whereas longer term climate evolution of the African continent is documented by a variety of terrestrial and marine records, the history of the northeastern and southeastern tropical Africa (e.g., Schneider et al., 1997; Johnson et al., 2002; Schefuß et al., 2005; Castañeda et al., 2007; Weldeab et al., 2007; Tierney et al., 2008, 2011; Ziegler et al., 2010; Otto-Bliesner et al., 2014) is better constrained than southern Africa. Southern African records are sparse, fragmented, and often suffer from a lack of robust age frameworks (e.g., Gasse et al., 2001; Partidge et al., 1997, 2004; Chase et al., 2007; Collins et al., 2014). Such information is important because variabil- ity is likely to have significantly influenced African biomes during the Pleistocene, and it appears that this has in turn affected the distributions of species as well as human demography (Scott et al., 2008).

Lake Malawi, the southernmost of the East African Rift lakes in the southern tropics, provides the only available continuous continental climate record of the last 1.3 My in southern East Africa. Reconstruction of temperature (using the organic proxy $\mathrm{TEX}_{86}$ ) and aridity (using leaf wax $\delta^{13} \mathrm{C}$ ) has been used to suggest a variable and predominantly arid climate that has $40 \mathrm{ky}$ periodicity prior to 900 $\mathrm{ka}$ (the mid-Pleistocene transition [MPT]), shifting to a more humid environment after the MPT (Johnson et al., 2016). After the MPT, the record has strong $100 \mathrm{ky}$ periodicity, with warmer and wetter conditions in interglacial intervals and relatively cool and dry glacial intervals (Johnson et al., 2016). The inferred shift in climate conditions across the MPT is supported by additional sedimentological proxies that indicate lower lake levels prior to the MPT followed by higher amplitude lake level variability and overfilled lake conditions until $\sim 100$ ka punctuated by intervals of short-lived extreme drought (Lyons et al., 2015). A similar story for the MPT is also found in the record of African $\mathrm{C}_{4}$ plant abundance from ODP Site 1077 in the tropical South Atlantic Ocean, although this record does not exhibit the shift toward overall more humid conditions for the last $900 \mathrm{ky}$ (Schefuß et al., 2003).

Millennial-scale climate variations are known from sediment cores off the Zambezi River, which drains into the Indian Ocean at $\sim 20^{\circ} \mathrm{S}$. A $\delta D_{\text {leaf wax }}$ record in sediment Core GeoB 9307-3 off the Zambezi River documents brief and distinctly wetter intervals that correlate with the Younger Dryas and Heinrich Stadial 1 (Schefuß et al., 2011). Together with BIT index (the relative abundances of branched glycerol dialkyl glycerol tetraethers [GDGTs] and the isoprenoid GDGT, crenarchaeol [Hopmans et al., 2004; Huguet et al., 2007]) and X-ray fluorescence data, this proxy record is taken to indicate that rainfall intensities and Zambezi sediment discharge increased because of a southward shift of the ITCZ during Northern Hemisphere cold events. However, in an apparent contradiction, the $\delta^{13} C_{\text {leaf wax }}$ record of this core shows an increased abundance of drought-tolerant $\mathrm{C}_{4}$ grasses during these inferred wet intervals. This discrepancy in $\mathrm{C}_{3}-\mathrm{C}_{4}$ plants may be attributed to shifts in source areas within the Zambezi subcatchments, as inferred from magnetic mineral inventories (Just et al., 2014), presumably due to changes in the locus of rainfall.

A more distal, deeper coring site $\sim 200 \mathrm{~km}$ north of the Zambezi River mouth at $\sim 1300 \mathrm{~m}$ water depth provides continuous sedimentary records spanning the last $\sim 40 \mathrm{ky}$. A high-resolution record of neodymium isotopes $(\varepsilon \mathrm{Nd})$ in the lithogenic clay fraction from one of the cores (64PE304-80) is interpreted to reflect changes in Zambezi sediment discharge relative to sediment transported from more northern sources by the strong net southward eddy-induced flow through the Mozambique Channel (van der Lubbe et al., 2016). The reconstructed intervals of enhanced Zambezi discharge are in agreement with the $\delta \mathrm{D}$ rainfall record obtained from a parallel core (GIK16160-30; Wang et al., 2013) after correction for the $\mathrm{C}_{3}-\mathrm{C}_{4}$ vegetation abundances.

Collectively, the evidence is consistent with the inference that the Zambezi Catchment experienced relatively wetter conditions during MIS 2 and the late Holocene, whereby Heinrich Stadial 1 and the Younger Dryas stand out as intervals of extreme wet conditions. More arid conditions occurred during MIS 3 and between $\sim 15$ and $5 \mathrm{ka}$. The later interval is synchronous with the African Humid Period in northern Africa. Altogether, Zambezi Catchment records 
document precession-paced changes in the African monsoonal rainfall belt with enhanced rainfall during periods of increased Southern Hemisphere summer insolation, superimposed by wet conditions during high-latitude Northern Hemisphere abrupt cold events.

Farther south, a $342 \mathrm{ky}$ pollen record from marine sediment Core MD96-2048 from $660 \mathrm{~m}$ water depth $\sim 120 \mathrm{~km}$ south of the Limpopo River mouth shows glacial-interglacial and precessioncorrelated climate variations in the extent of the subtropical biome (Dupont et al., 2011). On land the sediment record from Tswaing Crater, a meteorite impact north of Pretoria, provides the longest terrestrial record of climate variability in South Africa, spanning the last $200 \mathrm{ky}$. Clastic particle size variations from Tswaing Crater have also been used to suggest that cyclic changes in precipitation were linked with the long-term effect of regional insolation changes driven by orbital precession (Partridge, et al., 1997, 2004).

Marine sediment Core CD154-10-06P located off the east coast of subtropical South Africa, KwaZulu-Natal (KZN), reveals shifts in river runoff at the southeast African margin spanning the past 270 ky that also strongly follow orbital precession pacing (Figure F8). Xray fluorescence elemental data from Simon et al. (2015b) show humid phases that can be plausibly correlated with millennial-scale Northern Hemisphere cold events. These excursions extend those recently identified in similar data from Core CD154-17-17K, a little farther south, that were linked to periods of early modern human innovation during the middle Stone Age (Ziegler et al., 2013). Some of the millennial-scale events recorded in the eastern South Africa runoff records are coincident with periods of enhanced dune activity and mobility in the Kalahari and Namib Deserts and are thus consistent with the suggestion of shifted rainfall patterns and wind regimes (Stokes et al., 1999; Thomas et al., 2000; Stuut et al., 2002). Broadly, the conclusion drawn from the data is that past continental climate changes in southern Africa were linked with changes in ocean and atmospheric circulation that in turn varied due to precession of Earth's orbit. In some cases the changes were inferred to be associated with shifts of the ITCZ, and in other cases migration of the Antarctic Circumpolar Ocean fronts and/or the Southern Hemisphere mid-latitude westerly wind belt was likely influential.

A particularly intriguing feature of records from both stalagmites in coastal caves in South Africa (Bar-Matthews et al., 2010) and marine sediment cores at the southeast African continental margin (Schefuß et al., 2011; Wang et al., 2013; Ziegler et al., 2013; Just et al., 2014; van der Lubbe et al., 2014, 2016; Weldeab et al., 2014; Simon et al., 2015b) is the indication of recurrent but spatially variable millennial oscillations of rainfall patterns. Such variability demands highly resolved spatial and temporal records as well as numerical simulations.

Precession-only sensitivity experiments using a high-resolution, fully coupled ocean-atmosphere model (altering the seasonal and latitudinal distribution of solar insolation) show that during precession maxima (Pmax) higher Southern Hemisphere summer (DJF) insolation causes higher temperatures and lower surface pressure over the Southern Hemisphere, especially over land (Figure F9). Specifically, lower pressure during Pmax over South Africa and higher surface pressure over the southern Indian Ocean results in stronger easterly surface winds blowing toward eastern South Africa (Figure F9). Over land, convection also increases, resulting in greater precipitation and greater net precipitation (precipitation minus evaporation) over nearly all of southern Africa during Pmax. The enhanced precipitation during Pmax and associated higher surface runoff is particularly pronounced in the KZN and Eastern Cape
Figure F8. Long-term climate variability in eastern South Africa over the past 270,000 y from Simon et al. (2015b). A. $\delta^{18} \mathrm{O}$ splice from Chinese speleothems (green line) (Wang et al., 2001, 2008; Cheng et al., 2009) as presented in Barker et al. (2011) showing synchronous variability of the East Asian Monsoon with Northern Hemisphere summer insolation at $65^{\circ} \Delta \mathrm{N}$. Underlying gray bars indicate glacial-interglacial terminations (T). B. Fe/K ratios from Core CD154-10-06P (black line; five-point running mean, fine-tuned age model) indicating a more humid KwaZulu-Natal climate in accordance with varying austral summer (December-January) insolation at $30^{\circ} \Delta \mathrm{S}$. Light orange line shows initial age model based on global benthic Stack LR04 tuning. C. Pretoria Saltpan rainfall record (Partridge et al., 1997) with December insolation at $30^{\circ} \Delta$ S. D. Benthic foraminiferal (Cibicidoides spp.) $\delta^{18} \mathrm{O}$ record from Core CD154-10-06P (black = fine-tuned age model, light orange $=$ initial age model) reflecting global ice volume variability and local deep-water conditions in comparison with global benthic Stack LR04 (blue) (Lisiecki and Raymo, 2005). MIS = marine isotope stage. E. Age control points for Core $\mathrm{CD} 154-10-06 \mathrm{P}$ including radiocarbon dates (black), tuning of the foraminiferal $\delta^{18} \mathrm{O}$ record (light orange), and $\delta^{18} \mathrm{O}$ splice from Chinese speleothems on precession phase (green).

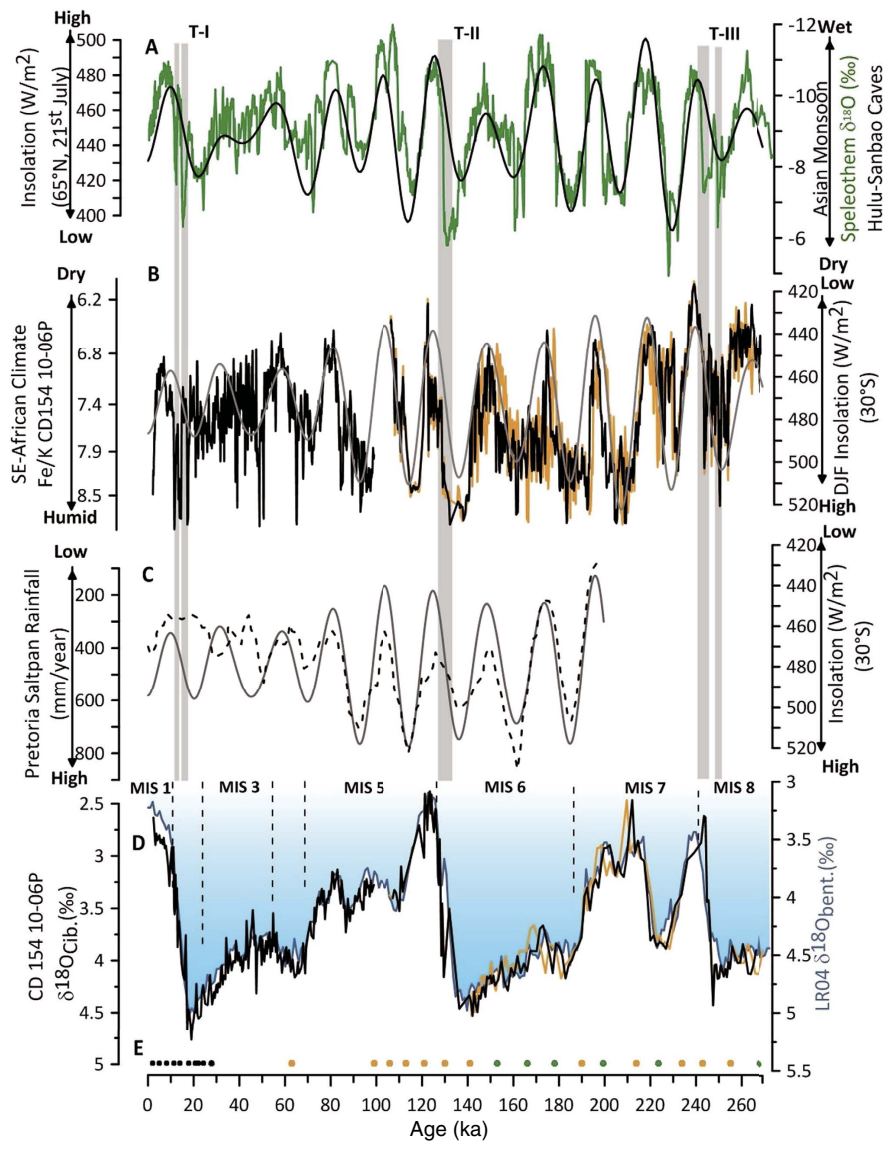

province region, compared to other regions further north or west, which may explain the considerable spatial variability observed in different core sites adjacent to land in the southwest Indian Ocean.

\section{Density profile of the LGM ocean}

The circulation of the deep ocean at the LGM is a crucial piece of the puzzle to understand past variations in $\mathrm{CO}_{2}$ and glacial-interglacial cycles more generally. Although the distribution of sedimentary deep-ocean circulation tracers $\left(\delta^{13} \mathrm{C}, \mathrm{Cd} / \mathrm{Ca}, \varepsilon \mathrm{Nd}\right.$, and $\delta^{18} \mathrm{O}$ ) indicate that LGM ocean circulation was likely different than that of the modern ocean (e.g., Rutberg et al., 2000; Piotrowski et al., 2004, 2005; Marchal and Curry, 2008; Lund et al., 2011) the distri- 
Figure F9. Results of idealized sensitivity modeling experiments showing the differences between maximum and minimum precession for December-February from experiments using high-resolution fully coupled ocean atmosphere model EC-Earth from Simon et al. (2015b). Figures were created using the model output and the program Ferret, version 6.82 for Macintosh (http://www.ferret.noaa.gov/Ferret/). A. Temperature. B. Precipitation. C. Vertical motion at 500 $\mathrm{hPa}$ (roughly $5 \mathrm{~km}$ ). Negative values indicate upward motion; positive values indicate downward motion. D. Surface runoff over land.

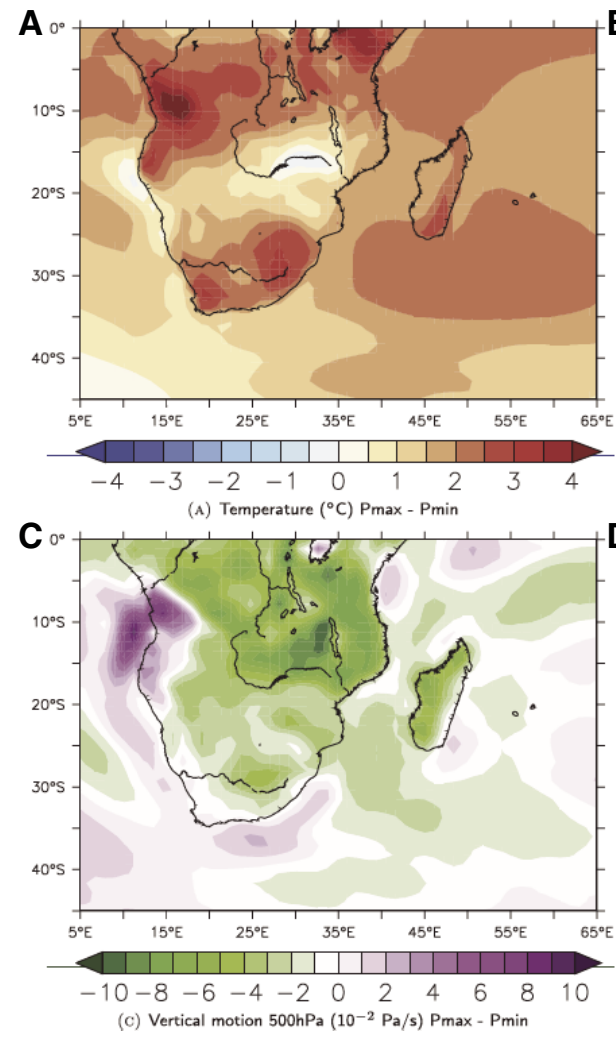

butions of these properties are inconclusive enough that they may also be consistent with modern circulation and differences in surface forcing (e.g., Gebbie, 2012; Gebbie and Huybers, 2006; LeGrand and Wunsch, 1995). Thus, to understand the role of the deep ocean in ice age climate variability, we require a more robust assessment of ice age deep-ocean variability, using a suite of tracers characterized by wide-ranging sensitivity to surface forcing.

In the modern ocean, we use the pattern of temperature and salinity to map the distribution of deep-water masses. In addition, these values inform the balance of sea-atmosphere exchange (i.e., precipitation, evaporation, heat exchange) processes that are required to create the negative buoyancy to form deep water; they are an integrated record of climate at high latitudes. It would be ideal to use the same strategy for the ice age ocean. However, there are few available means to develop a full temperature-salinity plot for the LGM. Schrag and DePaolo (1993) and Schrag et al. $(1996,2002)$ pioneered a strategy for quantifying the $\delta^{18} \mathrm{O}$ of seawater by sampling a profile of interstitial waters from deep-ocean sediment from IODP sites, making highly precise measurements of $\delta^{18} \mathrm{O}$ and applying diffusion models to estimate the value of LGM seawater. This strategy has been expanded to include $\left[\mathrm{Cl}^{-}\right]$, thus allowing an estimate of salinity (Adkins et al., 2002; Adkins, 2013; Miller et al., 2015). With local $\delta^{18} \mathrm{O}$ data from benthic foraminifers, interstitial water information from a coring site can be turned into a single point on the LGM temperature-salinity diagram. The current version of this plot, from sampling IODP material, contains only five pairs of points (Figure F10) (Adkins et al., 2002). The relative scarcity of the observations stems from the requirements of the approach: sedi-
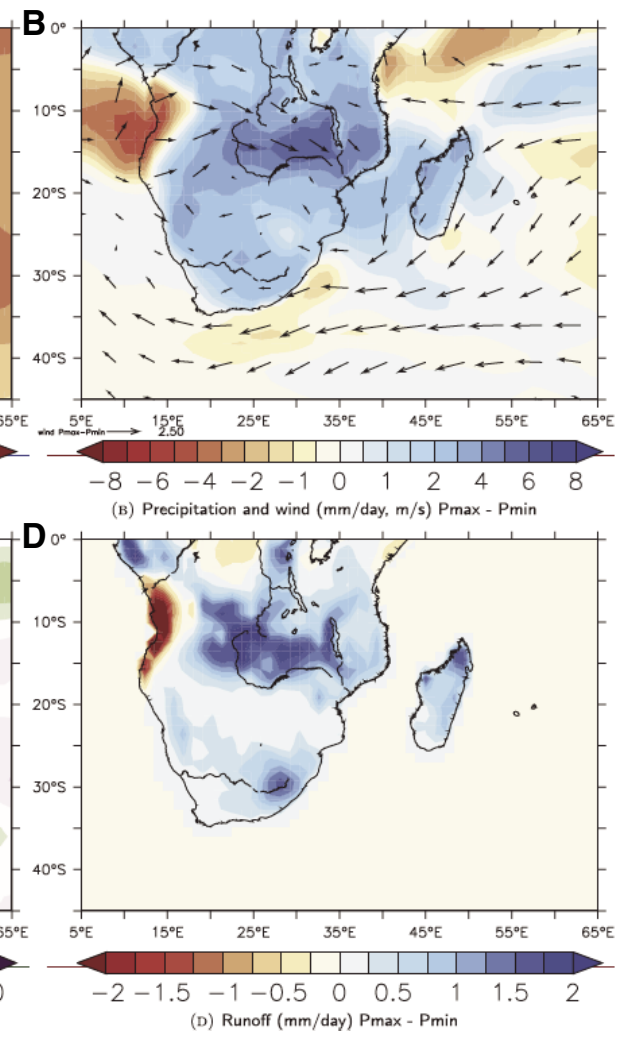

ment must be drilled to $>150 \mathrm{~m}$ below seafloor to properly measure and model the diffusion profile; a well-behaved sediment column, free of complicated fluid flow and diagenesis, must be sampled; and an entire hole must be dedicated to the pursuit. Nevertheless, despite the stringent requirements this approach is currently the most direct way to estimate temperature and salinity of the ice age deep ocean.

Although sparse, the existing data imply that there were largerthan-modern density differences between deep-ocean water masses at the LGM, and most of the ocean was close to the freezing point and therefore differences in density were due primarily to salinity (see also discussion in Miller et al., 2012). Most surprisingly, the salt gradient in the modern Atlantic Ocean, consisting of fresh southern-sourced waters and salty northern-sourced waters appears to have been reversed at the LGM. This suggests the saltiest waters of the LGM ocean originated in the Southern Hemisphere, although this inference is based on a single site (IODP Site 1093). Adkins et al. (2002) concluded that Glacial Southern Source Bottom Water was the densest water mass due to its high salinity. Enhanced density differences between northern- and southern-sourced bottom waters imply greater vertical stratification. A stronger vertical stratification would help explain indications that there was a physically isolated reservoir of $\mathrm{CO}_{2}$ in the deep ocean at the LGM (Broecker and Barker, 2007). In the years since the original work, analytical measurement of $\left[\mathrm{Cl}^{-}\right]$has been improved, several new sampling strategies have targeted increasing throughput, and the data analysis tools used to model the data have been improved. The next most important step in constraining the temperature, salinity, and density 
Figure F10. Temperature and salinity plot for modern (yellow) and LGM (blue) values. Based on the type of interstitial water data, this plot shows several differences with modern values. From Adkins and Schrag (2002).

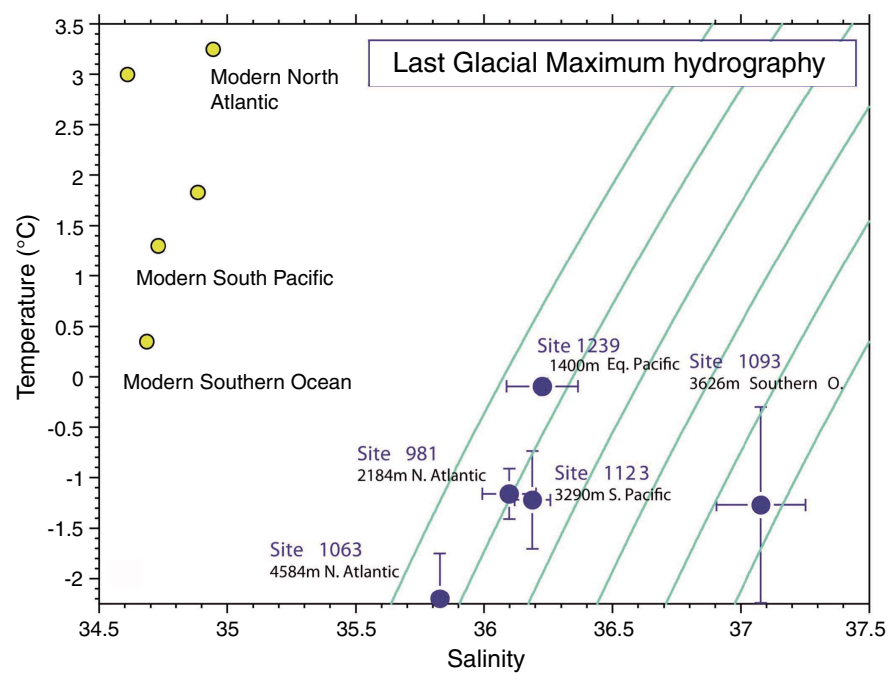

structure of the LGM deep ocean is to obtain depth transects of these properties and just generally more data from different parts of the ocean. To this end, samples taken during Expedition 361 sites ranging from 450 to $3040 \mathrm{~m}$ water depth will be used to help constrain the processes that could have filled the LGM deep ocean and controlled its circulation.

\section{Objectives}

Expedition 361 Pliocene-Pleistocene objectives include the following:

- To establish the sensitivity of the Agulhas Current to changing climates of the Pliocene-Pleistocene in association with transient to long-term changes of high-latitude climates, ocean gateways, tropical heat budgets, and the monsoon system;

- To determine the dynamics of the Indian-Atlantic Ocean gateway circulation during such climate changes in association with changing wind fields and migrating ocean fronts;

- To examine the connection between Agulhas leakage and ensuing buoyancy transfer and shifts of the AMOC during major ocean and climate reorganizations during at least the last $5 \mathrm{My}$; and

- To address the impact of Agulhas variability on southern Africa terrestrial climates and notably rainfall patterns and river runoff.

Specific scientific objectives include the following:

- To determine the variability of the greater Agulhas Current system under contrasting climatic regimes: Agulhas Current variability under early Pliocene warm conditions, during the midPliocene expansion of Northern Hemisphere ice sheets, and through the MPT;

- To establish the role of Agulhas leakage in transient and longterm shifts of the AMOC during these climatic transitions: proxy records of mode/strength of the Agulhas leakage during periods of major climatic reorganizations and for AMOC variations through the same intervals;

- To establish the response of the Agulhas Current system to Antarctic climate variability and bipolar linkages: evidence for vari- ation of the Agulhas leakage in highly resolved temporal records will be compared to Antarctic and bipolar climate changes, as well as with evidence for shifts of Southern Ocean fronts bordering the Agulhas corridor at the southern tip of Africa, and position and strength of the westerlies;

- To understand the remote tropical origins of Agulhas Current variability: evidence for variation of the Agulhas leakage in highly resolved temporal records will be compared to records of Indonesian Throughflow and monsoon modulation on the Agulhas Current source region and impacts on warm and saltwater transports along the southeast African margin and IndianAtlantic saltwater leakage;

- To better determine southern African climate sensitivity: comparison of varying Agulhas Current warm-water transports with rainfall patterns in southern Africa, in connection with the Pliocene-Pleistocene evolution of tropical climates, ITCZ migration, and tectonic history of eastern Africa; and

- To provide further verification of glacial-interglacial variations in the Southern Ocean's role in the carbon cycle: nutrient cycling, productivity, and $p \mathrm{CO}_{2}$ and their role in regional and global biogeochemical cycles.

Additionally, Expedition 361 will complete an intensive interstitial fluids program aimed at constraining the temperature, salinity, and density structure of the LGM deep ocean, from the bottom of the ocean to the base of the main thermocline. High-resolution interstitial water samples will be utilized for $\delta^{18} \mathrm{O}$ and chloride measurements to characterize the salinity of the bottom water and to deconvolve the temperature and ice volume control on $\delta^{18} \mathrm{O}$ of benthic foraminifers.

\section{Principal results Site U1474}

Site U1474 is located in the northernmost Natal Valley $\left(31^{\circ} 13.00^{\prime} \mathrm{S} ; 31^{\circ} 32.71^{\prime} \mathrm{E}\right) \sim 88 \mathrm{nmi}$ south-southeast of Durban, South Africa, in a water depth of $3034 \mathrm{~m}$ below sea level (mbsl). The Natal Valley is a sediment-filled basin between the coast of southeast Africa and Mozambique Ridge. At its northern end, the shoaling valley passes into the extensive coastal plains of southern Mozambique (Dingle et al., 1978; Goodlad, 1986), whereas toward the south the deepening Natal Valley merges with Transkei Basin below 4500 mbsl. Terrigenous sediment supply into the basin is dominated by seasonal discharge from the numerous short but fast-flowing rivers that characterize the drainage system of the Natal coast (e.g., the Tugela River), as well as contributions from the Limpopo River and possibly the Zambezi River. Surface sediment dispersal is strongly affected by the $\sim 100 \mathrm{~km}$ wide Agulhas Current flowing southward close to the continental shelf edge and transporting $\sim 70 \mathrm{~Sv}$ at $32^{\circ} \mathrm{S}$ (Beal and Bryden, 1999) with surface velocities up to $1.5 \mathrm{~m} / \mathrm{s}$. At depth, the northward-flowing Agulhas Undercurrent hugs the continental slope, presently transporting NADW. The currents related to this northward flow have led to the formation of a network of elongate, north-south-orientated sediment drifts.

According to Lutjeharms (2006a), the Agulhas Current is fully constituted at $\sim 26^{\circ} \mathrm{S}$, around Ponta do Ouro, close to the border between Mozambique and South Africa. Here, the East Madagascar Current converges with Mozambique Channel throughflow to form the Agulhas Current. The northern section of the Agulhas Current system, overlying Site U1474, is extraordinarily stable due to the steep, nearly rectilinear continental shelf that topographically steers 
the current flow southward (de Ruijter et al., 1999a; Lutjeharms, 2006a, 2007).

Several high-resolution orbital- to millennial-timescale records from shallow-penetration marine sediment cores located near Site U1474 (Ziegler et al., 2013; Simon et al., 2013, 2015a, 2015b) have provided multiproxy reconstruction of hydrographic variability within the main flow of the Agulhas Current as well as river discharge from the catchments of the Natal coast over the past $250 \mathrm{ky}$. In particular, Simon et al. (2013) demonstrated a strong correspondence between upstream Agulhas Current hydrographic variability and that of the Agulhas leakage corridor (deduced from foraminiferal proxies for temperature, salinity, and Agulhas leakage.) This system can be plausibly linked to the influence of recirculation within the southwest Indian Ocean subgyre, as predicted from physical oceanography (e.g., Gordon, 1985; Stramma and Lutjeharms, 1997). Additionally, it has been shown that changes in terrestrial climate (hydroclimate) are related to regional precessionpaced insolation changes and the effects associated with high-latitude abrupt climate forcing (Simon et al., 2015b). When considered in combination with archaeological records, these records appear to suggest links between climate and human settlement in South Africa during the middle Stone Age (Ziegler et al., 2013).

Our primary objective was to recover a key Pliocene-Pleistocene sedimentary succession, including the early Pliocene warm period, mid-Pliocene expansion of Northern Hemisphere ice sheets, and the MPT, formed under the influence of the upper reaches of the Agulhas Current. Site U1474 is ideally located to provide

- A reconstruction of Agulhas Current warm-water transports close to the start of the fully constituted Agulhas Current;

- An upstream record that may allow discerning connections between Agulhas leakage and its headwater variability;

- Evidence to understand the connections between southern African terrestrial climates and southeast Indian Ocean heat budgets, notably Agulhas Current warm-water transports and associated ocean-atmosphere heat and moisture transfer;

- A record of the vigor and hydrography of NADW (or its precursors) transported to the Circumpolar Deep Water (CDW) and the southwest Indian Ocean; and

- An interstitial water profile of $\delta^{18} \mathrm{O}$ and chloride ion concentration that can enhance the understanding of temperature, salinity, and density of the deep water bathing Site U1474 by providing an additional data point to the presently available pore water LGM temperature and salinity inventory.

Site U1474 consists of eight holes ranging in penetration depth from 3.1 to $254.1 \mathrm{~m}$ drilling depth below seafloor (DSF). Overall, 111 cores were recovered at this site. The advanced piston coring (APC) system penetrated $794.0 \mathrm{~m}$ and recovered $809.79 \mathrm{~m}$ of core (102\% recovery). The half-length APC (HLAPC) system penetrated $102.4 \mathrm{~m}$ and recovered $100.96 \mathrm{~m}$ of core ( $99 \%$ recovery). A total of $910.75 \mathrm{~m}$ of sediment was recovered from the $896.4 \mathrm{~m}$ interval cored (102\% recovery) at Site U1474. The total time spent at Site U1474 was 7.6 days (Table T1).

\section{Sedimentology}

The sediment at Site U1474 consists of one lithologic unit. Unit I (0-254.07 m CSF-A) a brown (uppermost $\sim 0.5 \mathrm{~m} \mathrm{CSF-A)} \mathrm{and}$ greenish gray (deeper than $0.5 \mathrm{~m}$ CSF-A) foraminifer-bearing clay with nannofossils alternating with intervals of greenish gray nannofossil-rich clay with or without foraminifers. Nannofossil-rich clay is more common downhole. Dark gray foraminifer-bearing fine- sand layers are common (typically $1-3$ per core) and range in thickness from a few centimeters to $\sim 2 \mathrm{~m}$ (most are a few centimeters thick). The composition of these sandy layers is predominantly quartz with carbonate, and many have erosional bases. Sediment includes dark gray mottling that we interpret as bioturbation. The relative intensity of the bioturbation typically increases with depth throughout. Sediment at Site U1474 also includes millimeter- to centimeter-scale green layers that contain pyrite and glauconite based on X-ray diffraction (XRD) and smear slide observations. These layers represent diagenetic alterations.

Significant drilling disturbance was observed in the first section of most of the cores and in the base of partial-stroke APC cores.

\section{Physical properties}

Despite the relatively homogeneous lithology, physical parameters vary along the entire sequence. Porosity increases with depth from 0 to $12.8 \mathrm{~m}$ core composite depth below seafloor (CCSF-A), reaching a maximum of $72 \%$ followed by a decrease to $<50 \%$ at the bottom of the cored section. This decreasing trend toward the bottom is likely due to compaction. Variations in gamma ray attenuation (GRA) density reflect the same compaction pattern. Natural gamma radiation (NGR) and magnetic susceptibility markedly decrease in the upper $10 \mathrm{~m}$ CCSF-A and increase to $130 \mathrm{~m}$ CCSF-A. Below 130 m CCSF-A, NGR and magnetic susceptibility values decrease to the base of the section. This decreasing trend occurs in spite of compaction and thus likely reflects decreasing abundances of clay and magnetic minerals within the sediment. Superimposed on the general trends are cyclic variations in NGR of typically $\sim 10-$ 15 counts/s, which may be related to the variable mixtures of terrigenous and biogenic sediment components. Fine-sand layers found throughout the cored section are clearly identified by peaks in magnetic susceptibility and GRA density values. Spectral reflectance shows a marked cyclic pattern downhole and broadly corresponds with the trends in color spectrometry values.

\section{Micropaleontology}

Analysis of calcareous nannofossils, planktonic and benthic foraminifers, and diatoms from core catcher and split-core samples from Hole U1474A indicates that Site U1474 spans the Late Pleistocene to the latest Miocene ( 6.2 Ma). Calcareous microfossils show good to moderate preservation in the upper $180 \mathrm{~m}$ CSF-A of the site. Below this depth, preservation and fossil group abundances decrease. A complete sequence of calcareous nannofossil zones was found from the late Miocene (Biozones NN11-NN21) to Late Pleistocene. Evidence for reworking of calcareous nannofossils is found throughout the entire sequence, marked by the persistent presence of early Miocene species. The calcareous nannofossil assemblages are typical of tropical to subtropical settings, although the temperate species, Coccolithus pelagicus, is found throughout the cored interval. Planktonic foraminifers also record a complete sequence of tropical biozones that span Miocene Biozone M13 to Late Pleistocene Subzone Pt1b. The planktonic foraminifer fauna is dominated by Globorotalia inflata, which is indicative of transitional environments between subtropical and polar water masses, and in deeper parts of the sequence the assemblage contains elements of the globoconellid group that are typical of subtropical convergence zones. Benthic foraminifer fauna is diverse and includes numerous suboxic components characteristic of a lower bathyal to abyssal environment. Siliceous microfossils are characteristic of a modern Indian Ocean assemblage and make up a minor component of the mudline sample. Below the mudline sample, sponge spicules are rare to trace 
Table T1. Expedition 361 hole summary. Download table in .csv format.

\begin{tabular}{|c|c|c|c|c|c|c|c|c|c|c|c|c|}
\hline Hole & Latitude & Longitude & $\begin{array}{l}\text { Seafloor depth } \\
\text { (mbrf) }\end{array}$ & $\begin{array}{c}\text { Cores } \\
(N)\end{array}$ & $\begin{array}{l}\text { Cored } \\
(\mathrm{m})\end{array}$ & $\begin{array}{l}\text { Recovered } \\
(\mathrm{m})\end{array}$ & $\begin{array}{l}\text { Recovery } \\
\text { (\%) }\end{array}$ & $\begin{array}{l}\text { Drilled } \\
(\mathrm{m})\end{array}$ & $\begin{array}{l}\text { Total penetration } \\
(\mathrm{m})\end{array}$ & $\begin{array}{l}\text { Total depth } \\
\text { (mbrf) }\end{array}$ & $\begin{array}{l}\text { Time on } \\
\text { hole }(\mathrm{h})\end{array}$ & $\begin{array}{l}\text { Time on } \\
\text { site (days) }\end{array}$ \\
\hline U1474A & $31^{\circ} 12.9995^{\prime} \mathrm{S}$ & $31^{\circ} 32.7080^{\prime} \mathrm{E}$ & 3044.6 & 29 & 254.1 & 264.83 & 104 & 0.0 & 254.1 & 3298.7 & 57.25 & 2.4 \\
\hline U1474B & $31^{\circ} 12.9882^{\prime} \mathrm{S}$ & $31^{\circ} 32.7083^{\prime} \mathrm{E}$ & 3045.2 & 16 & 147.3 & 142.09 & 96 & 0.0 & 147.3 & 3192.5 & 21.75 & 0.9 \\
\hline U1474C & $31^{\circ} 12.9999^{\prime} \mathrm{S}$ & $31^{\circ} 32.7215^{\prime} \mathrm{E}$ & 3050.0 & 1 & 3.1 & 3.07 & 99 & 0.0 & 3.1 & 3053.1 & 1.75 & 0.1 \\
\hline U1474D & $31^{\circ} 12.9999^{\prime} \mathrm{S}$ & $31^{\circ} 32.7213^{\prime} \mathrm{E}$ & 3045.2 & 14 & 124.5 & 126.04 & 101 & 0.0 & 124.5 & 3169.7 & 16.75 & 0.7 \\
\hline U1474E & $31^{\circ} 12.9995^{\prime} \mathrm{S}$ & $31^{\circ} 32.7208^{\prime} \mathrm{E}$ & 3045.2 & 17 & 112.0 & 114.44 & 102 & 107.0 & 219.0 & 3264.2 & 34.00 & 1.4 \\
\hline U1474F & $31^{\circ} 13.0105^{\prime} \mathrm{S}$ & $31^{\circ} 32.7078^{\prime} \mathrm{E}$ & 3046.8 & 32 & 236.4 & 240.49 & 102 & 2.0 & 238.4 & 3285.2 & 51.25 & 2.1 \\
\hline U1474G & $31^{\circ} 12.9995^{\prime} \mathrm{S}$ & $31^{\circ} 32.7080^{\prime} \mathrm{E}$ & 3044.6 & 1 & 9.5 & 9.97 & 105 & 0.0 & 9.5 & 3054.1 & 1.50 & 0.1 \\
\hline \multirow[t]{2}{*}{$\mathrm{U} 1474 \mathrm{H}$} & $31^{\circ} 12.9995^{\prime} \mathrm{S}$ & $31^{\circ} 32.7080^{\prime} \mathrm{E}$ & 3044.6 & 1 & 9.5 & 9.82 & 103 & 0.0 & 9.5 & 3054.1 & 1.50 & 0.1 \\
\hline & & & Site U1474 totals: & 111 & 896.4 & 910.75 & 102 & 109.0 & 1005.4 & & 185.83 & 7.6 \\
\hline U1475A & $41^{\circ} 25.6052^{\prime} \mathrm{S}$ & $25^{\circ} 15.6440^{\prime} \mathrm{E}$ & 2681.4 & 1 & 1.5 & 1.48 & 99 & 0.0 & 1.5 & 2682.9 & 11.25 & 0.5 \\
\hline U1475B & $41^{\circ} 25.6052^{\prime} \mathrm{S}$ & $25^{\circ} 15.6441^{\prime} \mathrm{E}$ & 2680.5 & 26 & 243.9 & 250.31 & 103 & 0.0 & 243.9 & 2924.4 & 25.50 & 1.1 \\
\hline U1475C & $41^{\circ} 25.5941^{\prime} \mathrm{S}$ & $25^{\circ} 15.6439^{\prime} \mathrm{E}$ & 2680.4 & 29 & 272.0 & 280.70 & 103 & 3.0 & 275.0 & 2955.4 & 29.00 & 1.2 \\
\hline U1475D & $41^{\circ} 25.6055^{\prime} \mathrm{S}$ & $25^{\circ} 15.6586^{\prime} \mathrm{E}$ & 2679.3 & 16 & 143.0 & 150.86 & 105 & 0.0 & 143.0 & 2822.4 & 19.00 & 0.8 \\
\hline U1475E & $41^{\circ} 25.6162^{\prime} \mathrm{S}$ & $25^{\circ} 15.6439^{\prime} \mathrm{E}$ & 2682.9 & 29 & 270.5 & 277.20 & 102 & 6.5 & 277.0 & 2959.9 & 33.00 & 1.4 \\
\hline \multirow[t]{2}{*}{ U1475F } & $41^{\circ} 25.6054^{\prime} \mathrm{S}$ & $25^{\circ} 15.6299^{\prime} \mathrm{E}$ & 2680.4 & 6 & 57.0 & 55.37 & 97 & 76.5 & 133.5 & 2813.9 & 20.00 & 0.8 \\
\hline & & & Site U1475 totals: & 107 & 987.9 & 1015.92 & 103 & 86.0 & 1073.9 & & 137.75 & 5.7 \\
\hline U1476A & $15^{\circ} 49.2535^{\prime} \mathrm{S}$ & $41^{\circ} 46.1242^{\prime} \mathrm{E}$ & 2176.8 & 24 & 224.2 & 232.90 & 104 & 0.0 & 224.2 & 2401.0 & 29.50 & 1.2 \\
\hline U1476B & $15^{\circ} 49.2421^{\prime} \mathrm{S}$ & $41^{\circ} 46.1234^{\prime} \mathrm{E}$ & 2177.6 & 16 & 148.4 & 154.42 & 104 & 0.0 & 148.4 & 2326.0 & 14.25 & 0.6 \\
\hline U1476C & $15^{\circ} 49.2526^{\prime} \mathrm{S}$ & $41^{\circ} 46.1355^{\prime} \mathrm{E}$ & 2176.6 & 1 & 5.7 & 5.72 & 100 & 0.0 & 5.7 & 2182.3 & 1.50 & 0.1 \\
\hline U1476D & $15^{\circ} 49.2525^{\prime}$ & $41^{\circ} 46.1358^{\prime} \mathrm{E}$ & 2176.6 & 24 & 228.0 & 237.02 & 104 & 1.0 & 229.0 & 2405.6 & 21.50 & 0.9 \\
\hline \multirow{2}{*}{ U1476E } & $15^{\circ} 49.2635^{\prime} \mathrm{S}$ & $41^{\circ} 46.1236^{\prime} \mathrm{E}$ & 2176.3 & 25 & 234.8 & 243.77 & 104 & 0.0 & 234.8 & 2411.1 & 31.75 & 1.3 \\
\hline & & & Site U1476 totals: & 90 & 841.1 & 873.83 & 104 & 1.0 & 842.1 & & 98.50 & 4.1 \\
\hline U1477A & $19^{\circ} 21.2930^{\prime} \mathrm{S}$ & $36^{\circ} 54.8962^{\prime} \mathrm{E}$ & 440.4 & 27 & 181.2 & 182.53 & 101 & 0.0 & 181.2 & 621.6 & 20.00 & 0.8 \\
\hline U1477B & $19^{\circ} 21.2822^{\prime} \mathrm{S}$ & $36^{\circ} 54.8958^{\prime} \mathrm{E}$ & 440.8 & 26 & 174.4 & 185.73 & 106 & 0.0 & 174.4 & 615.2 & 13.00 & 0.5 \\
\hline \multirow[t]{2}{*}{ U1477C } & $19^{\circ} 21.2928^{\prime} \mathrm{S}$ & $36^{\circ} 54.9066^{\prime} \mathrm{E}$ & 440.4 & 16 & 118.4 & 121.75 & 103 & 1.0 & 119.4 & 559.8 & 11.50 & 0.5 \\
\hline & & & Site U1477 totals: & 69 & 474.0 & 490.01 & 103 & 1.0 & 475.0 & & 44.50 & 1.8 \\
\hline U1478A & $25^{\circ} 49.2600^{\prime} \mathrm{S}$ & $34^{\circ} 46.1593^{\prime} \mathrm{E}$ & 499.2 & 32 & 248.4 & 256.96 & 103 & 0.0 & 248.4 & 747.6 & 19.25 & 0.8 \\
\hline U1478B & $25^{\circ} 49.2500^{\prime} \mathrm{S}$ & $34^{\circ} 46.1589^{\prime} \mathrm{E}$ & 499.2 & 33 & 246.3 & 246.85 & 100 & 1.0 & 247.3 & 746.5 & 16.25 & 0.7 \\
\hline U1478C & $25^{\circ} 49.2604^{\prime} \mathrm{S}$ & $34^{\circ} 46.1705^{\prime} \mathrm{E}$ & 501.2 & 33 & 238.3 & 242.32 & 102 & 10.0 & 248.3 & 749.5 & 16.00 & 0.7 \\
\hline \multirow[t]{2}{*}{ U1478D } & $25^{\circ} 49.2706^{\prime} \mathrm{S}$ & $34^{\circ} 46.1592^{\prime} \mathrm{E}$ & 502.0 & 21 & 172.7 & 175.97 & 102 & 43.3 & 216.0 & 718.0 & 14.25 & 0.6 \\
\hline & & & Site U1478 totals: & 119 & 905.7 & 922.10 & 102 & 54.3 & 960.0 & & 65.75 & 2.7 \\
\hline U1479A & $35^{\circ} 03.5290^{\prime} \mathrm{S}$ & $17^{\circ} 24.0620^{\prime} \mathrm{E}$ & 2629.9 & 1 & 1.0 & 1.01 & 101 & 0.0 & 1.0 & 2630.9 & 8.00 & 0.3 \\
\hline U1479B & $35^{\circ} 03.5289^{\prime} \mathrm{S}$ & $17^{\circ} 24.0621^{\prime} \mathrm{E}$ & 2629.7 & 32 & 300.7 & 296.73 & 99 & 0.0 & 300.7 & 2930.4 & 31.00 & 1.3 \\
\hline U1479C & $35^{\circ} 03.5183^{\prime} \mathrm{S}$ & $17^{\circ} 24.0621^{\prime} \mathrm{E}$ & 2629.7 & 31 & 294.5 & 303.69 & 103 & 1.0 & 295.5 & 2925.2 & 31.50 & 1.3 \\
\hline U1479D & $35^{\circ} 03.5286^{\prime} \mathrm{S}$ & $17^{\circ} 24.0754^{\prime} \mathrm{E}$ & 2626.5 & 11 & 101.4 & 102.15 & 101 & 2.0 & 103.4 & 2729.9 & 12.50 & 0.5 \\
\hline U1479E & $35^{\circ} 03.5402^{\prime} \mathrm{S}$ & $17^{\circ} 24.0623^{\prime} \mathrm{E}$ & 2626.5 & 15 & 142.5 & 148.17 & 104 & 134.0 & 276.5 & 2903.0 & 21.50 & 0.9 \\
\hline U1479F & $35^{\circ} 03.5290^{\prime} \mathrm{S}$ & $17^{\circ} 24.0493^{\prime} \mathrm{E}$ & 2626.7 & 1 & 9.5 & 9.50 & 100 & 0.0 & 9.5 & 2636.2 & 2.25 & 0.1 \\
\hline U1479G & $35^{\circ} 03.5290^{\prime} \mathrm{S}$ & $17^{\circ} 24.0493^{\prime} \mathrm{E}$ & 2623.9 & 1 & 9.3 & 9.29 & 100 & 0.0 & 9.3 & 2633.2 & 1.00 & 0.0 \\
\hline $\mathrm{U} 1479 \mathrm{H}$ & $35^{\circ} 03.5289^{\prime} \mathrm{S}$ & $17^{\circ} 24.0489^{\prime} \mathrm{E}$ & 2624.6 & 9 & 81.6 & 70.75 & 87 & 4.0 & 85.6 & 2710.2 & 8.75 & 0.4 \\
\hline \multirow[t]{3}{*}{ U1479| } & $35^{\circ} 03.5286^{\prime} \mathrm{S}$ & $17^{\circ} 24.0493^{\prime} \mathrm{E}$ & 2624.8 & 4 & 34.8 & 21.79 & 63 & 34.7 & 69.5 & 2694.3 & 27.00 & 1.1 \\
\hline & & & Site U1479 totals: & 105 & 975.3 & 963.08 & 99 & 175.7 & 1151.0 & & 143.50 & 6.0 \\
\hline & & Exp & edition 361 totals: & 601 & 5080.4 & 5175.69 & 102 & 427.0 & 5507.4 & & 675.75 & 28.0 \\
\hline
\end{tabular}

until they disappear completely below Sample 361-U1474A-10HCC (90.19 m CSF-A) and other siliceous fossils are not found.

The age model for Site U1474 is based on the biozonation of calcareous nannofossil and planktonic foraminifers. These data reveal that the recovered sedimentary sequence is free of hiatuses and that sedimentation rates are nearly constant throughout the recovered sequence (estimated to be $\sim 3.7 \mathrm{~cm} / \mathrm{ky}$ ). Near the bottom there appears to be a higher accumulation rate, but more shore-based work will be required to refine the age model.

\section{Paleomagnetism}

Paleomagnetic and rock magnetic analyses were carried out on sediment cores from Holes U1474A-U1474H. Analyses of discrete samples taken from Hole U1474A indicate that the magnetic mineralogy is dominated by magnetite. The relatively high saturation isothermal remanent magnetization (SIRM) and high and stable Sratios further reveal that magnetic minerals are well preserved throughout the sequence. Below $\sim 100 \mathrm{~m} \mathrm{CSF}-\mathrm{A}$, an increase of magnetic minerals is expressed by high SIRM. Inclination and declination records were obtained by measuring and demagnetizing the natural remanent magnetization (NRM) of archive core halves and discrete samples. The majority of the APC cores were oriented using the Icefield MI-5 tool. The inclination record is of good quality, and nine polarity zones can be identified. The boundaries of the Brunhes, Matuyama, Jaramillo, Olduvai, Gauss, Gilbert, C3n, and C3r (sub)paleomagnetic chrons constrain the chronology of the sediment and are in good agreement with the biostratigraphic data.

\section{Stratigraphic correlation}

Continuous and distinctive variations in magnetic susceptibility were used to make hole-to-hole correlations among Holes U1474A-U1474F. Confidence in these correlations is high because they can be cross-checked with continuous downcore measurements of color reflectance parameter L* and NGR. A complete affine table to the base of Hole U1474A was constructed to provide tabulated offsets for all cores relative to core depths (CSF-A). A con- 
tinuous splice was constructed downhole to $234 \mathrm{~m}$ CCSF-D using cores from Holes U1474D-U1474F where possible. For some intervals, it was necessary to use sections from Hole U1474A, but sequences in which whole-round samples had been removed were avoided. All sections of disturbed sediment were also avoided for construction of the splice. The continuity of the splice was confirmed with magnetic susceptibility, GRA density, NGR, and reflectance. Core intervals not included in the splice may be correlated to the CCSF-D depth scale using within-core variations of these data.

\section{Geochemistry}

Interstitial water chemistry shows a moderate degree of early sediment diagenesis at Site U1474. Profiles of Mn and Fe indicate suboxic conditions from the seafloor to $5 \mathrm{~m}$ CSF-A. Sulfate reduction occurs throughout much of the sediment column. The overall low organic carbon content, on average $<0.5 \mathrm{wt} \%$, does not support complete removal of sulfate by $250 \mathrm{~m}$ CSF-A, and methane concentrations remain at background levels. Carbonate content of the pelagic sediment is moderate, averaging $40 \mathrm{wt} \%$. The sandy layers contain significantly less carbonate than the nannofossil-rich clays, with values ranging between 20 and $30 \mathrm{wt} \%$. Profiles of conservative elements ( $\mathrm{K}$ and $\mathrm{Mg}$ ) downhole suggest either fluid flow or clay mineral alteration reactions at depths below $250 \mathrm{~m}$ CSF-A.

\section{Site U1475}

Site U1475 is located on the southwestern flank of Agulhas Plateau $\left(41^{\circ} 25.61^{\prime} \mathrm{S} ; 25^{\circ} 15.64^{\prime} \mathrm{E}\right) \sim 450 \mathrm{nmi}$ south of Port Elizabeth, South Africa, in a water depth of 2669 mbsl. The Agulhas Plateau, which was formed during the early stages of the opening of the South Atlantic at $90 \mathrm{Ma}$ (Parsiegla et al., 2008), is a major bathymetric high that is variably coated with sediment (Uenzelmann-Neben, 2001). The $230,000 \mathrm{~km}^{2}$ plateau, which ascends to $\sim 2500 \mathrm{~m}$ above the adjacent seafloor, is bounded on the north by the $4700 \mathrm{~m}$ deep Agulhas Passage and is flanked by Agulhas Basin in the west and Transkei Basin in the northeast. The northern part of the plateau is characterized by rugged topography, whereas the central and southern parts of the plateau exhibit relatively smooth topography (Allen and Tucholke, 1981) and have greater sediment thickness (Uenzelmann-Neben, 2001).

A strong flow of deep water passes over the Agulhas Plateau region (Macdonald, 1993), which involves the water column from the surface downward to the upper CDW. The hydrography of the upper ocean is dominated by the ARC, which comprises the component of the Agulhas Current that is not leaked to the South Atlantic Ocean but rather flows eastward from the Agulhas Retroflection (Lutjeharms and Ansorge, 2001). Antarctic Intermediate Water, below the ARC, also follows the same flow path near South Africa as the Agulhas Current and shows a similar retroflection (Lutjeharms, 1996). During its return to the southwest Indian Ocean, the ARC crosses the Agulhas Plateau, which deflects the deep-reaching current toward the Equator (Harris, 1970).

Site survey data collected during seismic cruises with the R/V Petr Kottsov in 1998 (Uenzelmann-Neben, 1998) and the R/V Marion Dufresne in 2002 show that Site U1475 is located on a sediment drift (Uenzelmann-Neben, 2001, 2002) that is deposited on the southwestern flank of Agulhas Plateau by NADW exiting the South Atlantic Ocean to the Indian Ocean. The wedge-shaped sediment drift thickens to the west, reaching a water depth of $\sim 2510 \mathrm{~m}$ at its crest. The wavy character of the seafloor topography and the subsurface seismic reflection pattern are interpreted as sediment waves that document sedimentation by active deep-water flow. Site U1475 is located at $2669 \mathrm{mbsl}$, near the drift crest where minor buried depressions create a locally expanded sequence.

Millennial-scale multiproxy records covering the past $350 \mathrm{ky}$ previously collected at this location highlight the synchrony of the regional ocean climatology and Antarctic climate variability. Evidence for regional ocean paleoclimatology includes latitudinal migrations of the Southern Ocean fronts and deposition of ice-rafted debris that document expansion of sub-Antarctic conditions to the plateau. These data serve as evidence for possible meridional shifts in the subantarctic frontal zone that borders the Agulhas leakage corridor and likely influences Agulhas leakage.

Paleoceanographic studies spanning the past $350 \mathrm{ky}$ combined with seismic reflection data support the suitability of Site U1475 to achieve our primary objectives, which are to

- Recover a complete Pliocene-Pleistocene sedimentary succession from a high-accumulation sediment drift located within the southern ARC sector of the Indian-Atlantic Ocean gateway;

- Assess the linking between Antarctic climate variations, circumpolar ocean front instability, and connections with Agulhas leakage into the South Atlantic Ocean;

- Assess the vigor and hydrography of NADW (or its precursors) exported to CDW and the southwest Indian Ocean at a location proximal to the entrance of NADW to the Southern Ocean and South Indian Ocean; and

- Evaluate the possibility of advective salinity feedbacks between Agulhas Leakage and AMOC variability, particularly the possible role of the Agulhas Leakage in modulating surface-to-deep ocean coupling in the North Atlantic during the transition between climatic states.

Site U1475 consists of six holes that range in depth from 1.5 to $277.0 \mathrm{~m}$ DSF. The APC system cored a total of $987.9 \mathrm{~m}$ and recovered $1015.92 \mathrm{~m}$ of core (103\% core recovery). Six intervals advanced without coring to provide a continuous stratigraphic sequence penetrated a total of $86.0 \mathrm{~m}$. The total time spent at Site U1475 was 5.7 days (Table T1).

\section{Sedimentology}

The sediment recovered at Site U1475 consists of two lithologic units. Unit I (0-4.75 m CSF-A) is composed of pale brown, light greenish or olive-gray, and white-gray nannofossil-rich foraminifer ooze. Unit II (4.75-277.22 m CSF-A) is composed of light greenish or pale gray to white-gray nannofossil ooze. Alternations between foraminifer-bearing or foraminifer-rich nannofossil ooze and nannofossil ooze with fine sand (foraminifers, quartz, and occasionally diatoms) were observed.

Sediment in both units includes dark gray mottling that we interpret as bioturbation (ichnofossil burrows [Planolites]). Thin darker bands commonly surround burrows, and macroscopic pyritized burrows are also common. Dropstones displaying coarse sand to granule grain sizes were observed in three different cores, which we interpret to represent ice-rafted debris. Sediment in both units also includes green layers that predominantly consist of pyrite and glauconite representing diagenetic alteration.

\section{Physical properties}

Despite the homogeneous lithology, physical parameters show downhole trends as well as cyclic variations. A marked change in physical sediment properties occurs at $\sim 110 \mathrm{~m}$ CSF-A. Above this depth, a change from quasi-regular short and lower amplitude variations to longer, higher amplitude, and more irregular cyclic varia- 
tion is observed. This change is most clearly displayed in NGR and color reflectance $\left(\mathrm{a}^{*}\right)$ data. In addition, $P$-wave velocities decrease and bulk densities increase at this depth, following a compaction trend. Prominent changes in $P$-wave velocity at Site U1475 can be clearly linked to seismic reflectors present in the site survey profiles.

\section{Micropaleontology}

Analysis of calcareous nannofossils, planktonic foraminifers, and diatoms from core catchers and working-half core samples from Holes U1475B, U1475C, and U1475E reveals that the $\sim 277 \mathrm{~m}$ section recovered at Site U1475 spans the latest Miocene ( 6.91 $\mathrm{Ma})$ to recent. Calcareous nannofossils show moderate to good preservation in all sequences with the consistent presence of wellpreserved Eocene to middle Miocene (reworked) species. The nannofossil chronostratigraphy at Site U1475 spans from Biozones NN21 to NN11 and CN15 to the Subzone CN9d/CN9c boundary. Calcareous nannofossil assemblages are characterized by species typical of tropical to subtropical and temperate environments. Planktonic foraminifer biota at Site U1475 are moderately to well preserved and are mostly composed of subtropical convergence species mixed with polar species. The Pleistocene foraminifer assemblage is dominated by G. inflata, which typically constitutes $30 \%-50 \%$ of each sample. Diatoms show poor to moderate preservation and have a mixed assemblage of subtropical and Southern Ocean taxa. Diatom markers from both environmental settings are used to define datums; however, the Southern Ocean assemblage abundance is greatly reduced below $101.62 \mathrm{~m}$ CSF-A. Overall, the diatom chronostratigraphy spans from Biozone NTD17 to NTD12.

Sedimentation rates at Site U1475, based on biostratigraphy and paleomagnetic reversals during the Pleistocene and latest Pliocene are nearly linear at $2.8 \mathrm{~cm} / \mathrm{ky}$ between 0 and $3.9 \mathrm{Ma}$. A significantly higher sedimentation rate of $9.6 \mathrm{~cm} / \mathrm{ky}$ occurs between 3.9 and 5.3 Ma. Finally, older than $5.3 \mathrm{Ma}$, sedimentation rates is again lower and is $\sim 2.5 \mathrm{~cm} / \mathrm{ky}$.

\section{Paleomagnetism}

All archive halves from Holes U1475B, U1475C, and U1475F and Cores 361-U1475E-1H through $15 \mathrm{H}$ were analyzed for NRM and demagnetized at 15 and $25 \mathrm{mT}$. In total, 98 discrete cube samples were taken from Holes U1475A, U1475B, and U1475D and subjected to NRM demagnetization. Cores from Site U1475 were not oriented because the relatively high latitude of the site implies that inclination data provide a reliable record of magnetic reversals. For most of the recovered interval, magnetic susceptibility measurements indicate that the sediment is diamagnetic in character and many readings are below the detection limit of the whole-round and point magnetic susceptibility instruments. Nonetheless, taken together, the inclination records of all individual holes provide a consistent and detailed magnetostratigraphy for Site U1475. The boundaries of the Brunhes, Matuyama, Jaramillo, Olduvai, Gauss, Kaena, and Mammoth paleomagnetic chrons and subchrons constrain the chronology of the sediment and are in general agreement with the biostratigraphic data.

\section{Stratigraphic correlation}

Select sequences from Holes U1475B, U1475C, U1475E, and $\mathrm{U} 1475 \mathrm{~F}$ were spliced together to create the most complete and representative section possible using RGB blue, b* color reflectance, and NGR data. Sedimentological logs were consulted meticulously in the process of constructing the splice to avoid inclusion of any obviously disturbed sections or sections with completely unique features (relative to the other adjacent holes). The splice constitutes a continuous sequence with a total length of $\sim 292$ m CCSF-D. However, confidence in the splice is low surrounding occasional problematic intervals, and further work on shore will be required to improve confidence.

\section{Geochemistry}

Interstitial water chemistry shows a moderate degree of early sediment diagenesis at Site U1475. The nitrate profile indicates suboxic conditions in the upper $0.25 \mathrm{~m}$ CSF-A. Sulfate concentrations decrease throughout the sediment column, and sulfate is never completely consumed. Methane concentrations remain at background levels. Carbonate is the dominant sedimentary component, ranging from 75 to $85 \mathrm{wt} \%$, with terrigenous material dominating the remaining fraction. Organic carbon contents range from 0.3 to $0.6 \mathrm{wt} \%$, decreasing slightly downhole. Together, carbonate, organic carbon, and elemental biogenic indicator profiles suggest that export production increased into the Late Pleistocene.

\section{Site U1476}

Site U1476 is located on Davie Ridge at the northern entrance of the Mozambique Channel $\left(15^{\circ} 49.25^{\prime} \mathrm{S} ; 41^{\circ} 46.12^{\prime} \mathrm{E}\right)$ at a water depth of $2165 \mathrm{mbsl}$. It is $3 \mathrm{nmi}$ northwest of DSDP Site 242 .

The Mozambique Channel is considered to be one of the most turbulent areas in the world ocean (Ternon et al., 2014), bordered by Madagascar to the east and Mozambique to the west. At its southern end, flow through the channel feeds into the greater Agulhas Current system. The Mozambique Channel is characterized by complex and variable surface and subsurface circulation. Several water masses converge within the Mozambique Channel, and the circulation is dominated by activity related to the inflow of both Indonesian Throughflow and Tasman Strait Throughflow as well as the strength of the tropical and subtropical surface gyres in the Indian Ocean (Palastanga et al., 2006; Penven et al., 2006; Schott et al., 2009; Backeberg and Reason, 2010; Ridderinkhof et al., 2010). Satellite observations (e.g., Schouten et al., 2003; Quartly and Srokosz, 2004) and ocean models (Biastoch and Krauss, 1999) have shown that mesoscale anticyclonic eddies generally form as the channel narrows close to Davie Ridge (at about $16^{\circ} \mathrm{S}$ ), between the northern and central basin of the Mozambique Channel. These eddies typically maintain a high rotational velocity, often $>1.5 \mathrm{~m} / \mathrm{s}$ (Schouten et al., 2003; Ullgren et al., 2012) as they migrate southward through the channel at a mean rate of $\sim 4-7$ eddies per year. Accordingly, processes in the Mozambique Channel have downstream implications for the Agulhas Current including leakage into the South Atlantic Ocean (e.g., Bryden et al., 2005; Biastoch et al., 2008, 2009b). Mozambique Channel eddies may also be linked with interannual modes of Indian and Pacific Ocean variability, implying a connection with the Indian Ocean Dipole and Pacific Ocean La Niña/El Niño phases (Schouten et al., 2002a; Palastanga et al., 2006).

Limited paleoceanographic evidence currently exists to document the longer term linkage between variability in the northern source waters of the Agulhas Current and its eventual leakage into the South Atlantic Ocean. The primary objectives at Site U1476 are to

- Recover a complete Pliocene-Pleistocene sedimentary succession including the early Pliocene warm period, the mid-Pliocene expansion of Northern Hemisphere ice sheets, and the MPT; 
- Reconstruct Mozambique Current warm-water transports during periods of orbitally modulated and suborbitally accelerated climate changes; and

- Assess the influence of remote upstream forcing on southeast African warm-water transport.

Specific questions that will be addressed include Did the restriction of the Indonesian Seaway and the associated change of the Indonesian Throughflow in the Pliocene affect the Agulhas Current source region in the western tropical Indian Ocean and subsequently impact warm-water and saltwater transports along the southeast African margin? Did the Agulhas Current respond to the long-term development of tropical climates and the associated weakening of the monsoons in the course of the global cooling of the Pliocene?

Site U1476 consists of five holes that penetrated from 5.7 to $234.8 \mathrm{~m}$ DSF. The APC system penetrated a total of $841.1 \mathrm{~m}$ and recovered $873.83 \mathrm{~m}$ of core (104\%). One interval was advanced 1.0 $\mathrm{m}$ without coring to adjust coring gaps to provide a continuous stratigraphic sequence. The total time spent at Site U1476 was 4.1 days (Table T1).

\section{Sedimentology}

Two lithologic units were described at Site U1476. Unit I (0$34.57 \mathrm{~m}$ CSF-A) is composed of light brown to greenish gray foraminifer ooze with nannofossils alternating with foraminifer-rich nannofossil ooze. Unit II (34.57-235.41 m CSF-A) is composed of greenish gray foraminifer-rich nannofossil ooze and nannofossil ooze with foraminifers, silt, and clay.

Sediment in both units includes dark gray mottling that we interpret as bioturbation. Thin darker bands commonly surround burrows, and macroscopic pyritized burrows are common. Sediment also includes green layers that predominantly consist of pyrite and glauconite, which are diagenetic alterations. Only minor coring disturbance is observed in the cores.

\section{Physical properties}

Despite the relatively homogeneous lithology, different physical parameters show significant trends downhole as well as cyclic variations along the sediment column. High-amplitude cyclic changes occur in the uppermost $16 \mathrm{~m}$ CSF-A of all holes. These cyclic changes continue downward to the bottom of the holes with lower amplitude and higher frequency. Variations in color reflectance indicate sediment compositional changes and RGB data broadly correspond with color reflectance parameter $L *$. Bulk densities increase downhole due to compaction, but there are large variations in the uppermost $16 \mathrm{~m} \mathrm{CSF-A} \mathrm{that} \mathrm{are} \mathrm{also} \mathrm{seen} \mathrm{in} \mathrm{the} \mathrm{other} \mathrm{physi-}$ cal properties.

\section{Micropaleontology}

Calcareous nannofossil and planktonic foraminifer biostratigraphy indicates that Hole U1476A spans the Late Pleistocene to late Miocene. Diatoms are barren throughout the section except for tropical diatoms present in minor amounts in the mudline sample. Calcareous microfossils show very good preservation in Plioceneto Pleistocene-age sediment; however, the late Miocene samples are characterized by an increase of fragmented planktonic foraminifers. Assemblages in both microfossil groups include tropical to subtropical forms with the periodic appearance of species typical of temperate environments. Sedimentation rates, based on calcareous nannofossil and planktonic foraminifer datums, increase from 2.3 to $3.5 \mathrm{~cm} / \mathrm{ky}$ downhole. No hiatuses were observed; however, events that are seemingly diachronous were observed within the planktonic foraminifer biochronology. These events might suggest that calibration of microfossil datums from the tropical western Indian Ocean need refinement.

\section{Paleomagnetism}

Paleomagnetic and rock magnetic analyses were carried out on sediment cores from Holes U1476A, U1476B, U1476D, and U1476E. All together, the rock magnetic data imply that the concentration of high-coercivity minerals (e.g., hematite and titanomagnetite) is relatively stable, whereas magnetite concentrations decrease below $\sim 150 \mathrm{~m}$ CSF-A. Demagnetization of NRM carried out on discrete samples and archive halves shows that the directional record carries a strong coring overprint. The uppermost two sections of each core reveal steep downward inclinations after demagnetization at maximum levels of $25 \mathrm{mT}$, suggesting that the applied field was too weak to remove the overprint. More detailed demagnetization experiments on discrete samples show changes in inclination after demagnetization of $40 \mathrm{mT}$, suggesting that sediment has an early diagenetic overprint that might be removed by demagnetization at higher fields. Because the Icefield MI- 5 orientation tool malfunctioned, the declination data could not be corrected for core orientation and can therefore not be used for assigning polarity zones. A more detailed investigation of demagnetization behavior will be needed to establish a more confident paleomagnetic stratigraphy for Site U1476.

\section{Stratigraphic correlation}

Ideal coring conditions and good signal in the magnetic susceptibility measurements allowed for near-real time correlation at Site U1476. Coring offsets were applied in Holes U1476A and U1476D so that no gaps were present downhole to the full depth of the holes (229.0 m CSF-A). Hole U1476E provided similar offsets to Hole U1476A so that a splice could be constructed primarily between Holes U1476D and U1476E. The splice was constructed using magnetic susceptibility data and confirmed using NGR and RGB (blue) data.

\section{Geochemistry}

Interstitial water chemistry shows mild early sediment diagenesis at Site U1476. Nitrate and sulfate, two species that disappear with progressively more intense microbial respiration, persist deeper into the sediment column and at higher concentrations than was documented at Sites U1474 or U1475. Methane concentrations remain at or near background levels. Decreasing concentrations of major elements, such as potassium and sodium, reflect uptake by clay minerals. Carbonate is variable (45-75 wt\%), with terrigenous sediment making up the remainder of the sediment. The sediment is organic carbon poor, with average concentrations of $0.24 \mathrm{wt} \%$ total organic carbon (TOC).

\section{Site U1477}

Site U1477 is located in the western Mozambique Channel on the upper continental slope $\left(19^{\circ} 21.29^{\prime} \mathrm{S} ; 36^{\circ} 54.90^{\prime} \mathrm{E}\right), \sim 65 \mathrm{nmi}$ east of the Zambezi River delta region, at a water depth of $429.2 \mathrm{mbsl}$.

Site U1477 receives fluvial material exported from the Zambezi Catchment, which is in the southernmost reach of the African monsoonal precipitation belt and drains multiple subbasins. Collectively, these subbasins span $\sim 1.385$ million $\mathrm{km}^{2}$ and the river itself extends more than $2500 \mathrm{~km}$. Annual precipitation across the Zambezi Catchment varies spatially with $\sim 150 \mathrm{~cm} / \mathrm{y}$ in the northern 
catchment region, $\sim 85 \mathrm{~cm} / \mathrm{y}$ in the southern region, and $60-70$ $\mathrm{cm} / \mathrm{y}$ in the central region (Ronco et al., 2006). Peak precipitation in the Zambezi Catchment occurs during the austral summer (DJF), when the ITCZ is located at its most southerly position.

The mean outflow of the Zambezi River is $3000 \mathrm{~m}^{3} / \mathrm{s}$ (Gammelsrød, 1992), and it transports an annual sediment load of $\sim 51 \mathrm{Mm}^{3}$, making it the largest single source of suspended sediment supply to the Mozambique margin (Walford et al., 2005). This fluvial sediment mixes with current-transported and biogenic material and forms a major component of the extensive current-controlled sedimentary deposits that characterize the Mozambique margin. Recent work on shorter cores demonstrates that the strata here have the potential to provide comprehensive proxy records of regional oceanographic changes as well as changes in hydrological conditions of the African precipitation belt in southeastern Africa (e.g., Schefuß et al., 2011; Schulz et al., 2011; Wang et al., 2013; Weldeab et al., 2013, 2014; Just et al., 2014; van der Lubbe et al., 2014, 2016).

Site U1477 is positioned on a contourite drift deposited under the influence of the eddy-dominated water flow through the Mozambique Channel. The drift displays packages of parallel and laterally continuous subseafloor reflectors. Site U1477 is immediately southwest of the $6.51 \mathrm{~m}$ long sediment core GeoB9307-3 $\left(18^{\circ} 33.99^{\prime} \mathrm{S}, 37^{\circ} 22.89^{\prime} \mathrm{E} ; 542 \mathrm{mbsl}\right.$ ) (Schefuß et al., 2011). The site was selected because Core GeoB9307-3 showed elevated sedimentation rates during the deglacial period to the Holocene and thus suggested the great potential of Site U1477 for providing a centennial-scale paleoceanographic record. As noted below, the site had almost 10 times higher accumulation than Core GeoB9307-3, so the primary objectives for the site are necessarily modified from the original objectives.

The Site U1477 primary objectives are to

- Recover a complete high-resolution sedimentary succession that spans the last $2 \mathrm{My}$, including the MPT, from the Mozambique margin close to the Zambezi River delta (we only recovered $<200$ ky because of the extremely high accumulation rate);

- Generate a high-resolution Pleistocene profile of southern African continental climate changes on orbital and suborbital timescales;

- Establish linking between southern African terrestrial climates and southwest Indian Ocean heat budgets, notably warm-water transport along the southeast African margin and associated ocean-atmosphere heat and moisture transfer;

- Examine the relationship between such climate variability and early human evolution (this objective could not be achieved due to the extreme accumulation rate); and

- Reconstruct upstream control on Agulhas leakage through headwater variability during periods of orbitally modulated and suborbitally accelerated climate changes.

The stratigraphic extent of Site U1477 was considerably shorter than anticipated, with a basal age of $<200 \mathrm{ka}$. As a result, the paleoclimate site objectives will require adjustment to focus on hightemporal timescale variability (decadal-centennial) over the last glacial cycle. The remarkably high sedimentation rates at Site U1477 promise an unprecedented opportunity to investigate hydroclimate variability in southeastern Africa and its potential links to changes in the greater Agulhas Current system. A specific question that will be addressed is whether variable Agulhas Current warmwater transport contributes to and modulates the impacts of shifting air boundaries and rainfall patterns over southeast Africa, and possibly offsets these patterns from those over southwest Africa and the Namib (Dupont et al., 2005, 2011; Maslin et al., 2012; Castañeda et al., 2016).

Site U1477 consists of three holes that penetrated from 119.4 to $181.2 \mathrm{~m}$ DSF. A total of $490.01 \mathrm{~m}$ of core was taken over a $474.0 \mathrm{~m}$ cored interval (103\%). The APC system penetrated a total of 296.2 $\mathrm{m}$ and recovered $308.07 \mathrm{~m}$ of core (104\%). The HLAPC recovered $174.00 \mathrm{~m}$ of sediment over a $169.2 \mathrm{~m}$ interval (103\%). The extended core barrel $(\mathrm{XCB})$ was deployed for one core resulting in $7.96 \mathrm{~m}$ of sediment (97\%). One interval was advanced $1.0 \mathrm{~m}$ without coring to offset the otherwise aligned coring gaps for obtaining a continuous stratigraphic sequence. The total time spent at Site U1477 was 1.8 days (Table T1).

\section{Sedimentology}

Sediment at Site U1477 consists of two lithologic units. Unit I (0-0.5 m CSF-A) is composed of very dark gray to dark greenish gray sandy clay with foraminifers and nannofossils. Unit II (0.5254.07 m CSF-A) is composed of very dark gray to dark greenish gray silty clay with intermittent to frequent occurrences of sand layers. These sand layers contain quartz and clay, and thicknesses range from centimeter to meter scale.

Bioturbation is not apparent in either unit. Macrofossils, including bivalve and echinoderm fragments, are present throughout the cores. Many of the cores show disturbance related to gas expansion.

\section{Physical properties}

Despite the relatively homogeneous lithology, physical properties at Site U1477 show a complex pattern of high-amplitude changes that are likely caused by climate-related variations in terrigenous sediment supply and/or current sorting effects. However, some excursions to lower values in NGR and GRA bulk density data may be due to the voids caused by gas expansion. Also, collection of reliable $P$-wave data below $16.9 \mathrm{~m} \mathrm{CSF-A} \mathrm{in} \mathrm{all} \mathrm{of} \mathrm{the} \mathrm{holes} \mathrm{was} \mathrm{in-}$ hibited by strong signal attenuation resulting from the frequent occurrence of gas expansion voids. Porosities at Site U1477 decrease downhole, and average porosities are significantly lower when compared to the previous sites (U1474-U1476).

\section{Micropaleontology}

Site U1477 spans the Holocene to the Late Pleistocene. Two biostratigraphic datums were observed: the abundance crossover from Gephyrocapsa caribbeanica to Emiliana huxleyi at $\sim 90 \mathrm{ky}$ and the top occurrence of Globigerinoides ruber (pink) at $120 \mathrm{ky}$. Sedimentation rates, estimated from biostratigraphic datums as well as radiocarbon ages tied in from a nearby piston core (van der Lubbe et al., 2014), suggest deposition rates of $\sim 1.5 \mathrm{~m} / \mathrm{ky}$ from 0 to $\sim 30 \mathrm{~m}$ CSF-A in Hole U1477A that decrease to $\sim 83 \mathrm{~cm} / \mathrm{ky}$ from $\sim 30 \mathrm{~m}$ CSF-A to the base of the hole. Calcareous microfossils are generally well preserved, although abundance is typically low. Planktonic foraminifer tests compose $<1 \%$ of sediment particles in most samples, and fewer than 50 nannofossils per field of view were observed throughout most of the section. The planktonic assemblage includes the regular occurrence of pteropods, benthic foraminifers, ostracods, sponge and gorgonian spicules, mollusks, echinoderm plates, and fish otoliths. Siliceous microfossils make up a minor component of the mudline and core catcher samples where marine and freshwater diatoms, phytoliths, and sponge spicules are present, providing indications of both terrestrial and marine sources. Siliceous microfossils were not found in samples below the mudline. 


\section{Paleomagnetism}

Paleomagnetic measurements at Site U1477 show a clear magnetic signal. For all holes, inclinations center around $-50^{\circ}$ as expected for the site location during the Brunhes Chron. Rockmagnetic data acquired on discrete samples reveal phases of high ferrimagnetic mineral content that largely match magnetic susceptibility data collected on archive section halves and whole cores. Variations in magnetic mineral compositions reflect either a change in the composition of the terrigenous fraction or preferential mineral dissolution.

\section{Stratigraphic correlation}

Real-time stratigraphic correlation was possible at Site U1477 using magnetic susceptibility data. Holes U1477A-U1477C were

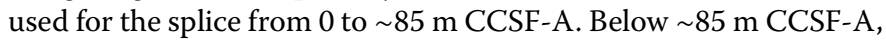
the splice consists primarily of sediment from Hole U1477B, with a couple of exceptions where intervals of Hole U1477A were used. A continuous stratigraphic splice was not possible to achieve at this site because of substantial gas expansion that led to core fracturing and variable core stretching between holes.

\section{Geochemistry}

Interstitial water chemistry and headspace gas concentrations show relatively intense early sediment diagenesis at Site U1477. The sulfate-methane transition appears at $\sim 16 \mathrm{~m}$ CSF-A, below which sulfate is completely consumed and methane concentrations increase rapidly to a peak of $\sim 75,500 \mathrm{ppmv}$ at $\sim 35 \mathrm{~m}$ CSF-A. Other redox-sensitive elements, including iron, manganese, and barium, show enrichments caused by remobilization. Terrigenous sediment is the dominant constituent of the core. Carbonate contents average $5 \mathrm{wt} \%$, with a few intermittent layers rich in shell material with carbonate contents as high as $\sim 20 \mathrm{wt} \%$. The average TOC content is $0.61 \mathrm{wt} \%$.

\section{Site U1478}

Site U1478 is located in the Delagoa Bight on the Inharrime Terrace $\left(25^{\circ} 49.26^{\prime} \mathrm{S} ; 34^{\circ} 46.16^{\prime} \mathrm{E}\right) \sim 75 \mathrm{nmi}$ east of the Limpopo River at a water depth of $488 \mathrm{mbsl}$.

The Delagoa Bight is a distinct indentation of the continental margin (Lamont et al., 2010) into which the Limpopo River, the second largest eastward-draining river in Africa, deposits sediment. The hydrography of the Delagoa Bight is influenced by the southerly flowing waters from the Mozambique Channel and the East Madagascar Current (Lutjeharms, 2006a, 2006b), the confluence of which forms the Agulhas Current. The Limpopo Catchment is a little over $410,000 \mathrm{~km}^{2}$, considerably smaller than that of the neighboring Zambezi River. The Limpopo River has a mean annual discharge of $\sim 170 \mathrm{~m}^{3} / \mathrm{s}$ and delivers annual sediment loads of $33 \mathrm{Mt} / \mathrm{y}$ (Milliman and Meade, 1983) to the Delagoa Bight.

The Site U1478 primary objectives are to

- Recover a complete high-resolution sedimentary succession that spans the last $2 \mathrm{My}$;

- Generate a high-resolution Pleistocene profile of southern African continental climate changes on orbital and suborbital timescales;

- Establish linking between southern African terrestrial climates and southwest Indian Ocean heat budgets, notably warm-water transports along the southeast African margin and associated ocean-atmosphere heat and moisture transfer;

- Examine the relationship between such climate variability and early human evolution; and
- Reconstruct upstream control on Agulhas leakage through headwater variability during periods of orbitally modulated and suborbitally accelerated climate changes.

Specific questions that will be addressed include Did the longterm climatic developments of the Pleistocene, through their impact on atmospheric circulation, alter the rainfall patterns over southeast Africa? Did variable Agulhas Current warm-water transports contribute to and modulate the impacts of shifting air boundaries and rainfall patterns over southeast Africa and possibly offset these patterns from those over southwest Africa and the Namib (Dupont et al., 2005; Maslin et al., 2012)?

Site U1478 consists of four holes that penetrated from 216.0 to 248.4 m DSF. A total of $922.1 \mathrm{~m}$ of core was recovered over a 905.7 $\mathrm{m}$ interval (102\%). The APC system penetrated a total of $698.9 \mathrm{~m}$ and recovered $708.66 \mathrm{~m}$ of core (101\%). The HLAPC recovered a total of $213.4 \mathrm{~m}$ of sediment over a $206.8 \mathrm{~m}$ cored interval (103\%). Five intervals were advanced $54.3 \mathrm{~m}$ without coring to adjust coring gaps to provide a continuous stratigraphic sequence. The total time spent at Site U1478 was 2.7 days.

\section{Sedimentology}

Sediment at Site U1478 consists of one lithologic unit. Unit I (0$248.59 \mathrm{~m} \mathrm{CSF}-\mathrm{A}$ ) is composed of dark olive-gray and dark greenish gray sand with foraminifers and nannofossils that alternate with clayey or sandy silt with foraminifers and nannofossils. The sand is predominantly composed of quartz.

Bioturbation is rare; however, the coarser grained sediment at Site U1478 may obscure sedimentary structures such as bioturbation and diagenetic alterations. Macrofossils, including bivalves, gastropods, and echinoderms, are present throughout the cores.

\section{Physical properties}

The physical properties measured at Site U1478 show a complex pattern of amplitude changes and trends. All high-resolution records derived by physical properties core logging (magnetic susceptibility, NGR, GRA bulk density, RGB color, and spectral reflectance) show cyclic changes that are likely related to the variable lithologic alternations between silt-rich and sand-rich intervals. These cyclic changes are pervasive throughout the sequence and probably reflect complex interactions between ocean circulation, sea-level fluctuations, and fluvial discharges recorded at Site U1478. Two zones of very low magnetic susceptibility values at 89-92 and 164-168 m CSF-A may be related to sediment diagenesis as indicated by elevated iron and manganese concentrations in the interstitial water. Porosities decrease downhole, and average porosities are similar to those at Site U1477 but are significantly lower compared to the deeper water Sites U1474-U1476.

\section{Micropaleontology}

Biostratigraphy of calcareous nannofossils and planktonic foraminifers indicates that Hole U1478A spans the Late Pleistocene to the middle Pliocene with a basal age of $\sim 4 \mathrm{Ma}$. Calcareous microfossil assemblages include warm subtropical to tropical species in combination with coastal taxa. Planktonic foraminifers and calcareous nannofossils are abundant throughout Site U1478. Foraminifers dominate sandy beds, whereas calcareous nannofossils are typically more abundant in silty and clay-rich intervals. Glassy and translucent foraminifers are found throughout most of the recovered sequence, although fragmentation is apparent in the oldest parts of the sequence. Calcareous nannofossils are mostly well preserved, but the Discoaster group commonly exhibits fragmentation of the 
delicate arms. Diatoms are present only in surface sediment, and sponge spicules and phytoliths are scarce in the lower parts of the sequence. Low levels of reworking are evident in planktonic foraminifer records. The biochronology for both calcareous microfossil groups reveals sedimentation rates of $\sim 9 \mathrm{~cm} / \mathrm{ky}$ between the Late Pleistocene and $\sim 2.1 \mathrm{Ma}$ and lower rates of $2.9-5.3 \mathrm{~cm} / \mathrm{ky}$ older than 2.1 Ma. Planktonic foraminifers and calcareous nannofossils give diverging age-depth relationships between 1.9 and $3 \mathrm{Ma}$, which is possibly linked to sedimentological processes. The two fossil groups are in agreement in the lowermost $\sim 25 \mathrm{~m}$ of Site U1478 and indicate a basal age of 4-4.1 Ma.

\section{Paleomagnetism}

Rock magnetic and paleomagnetic analyses were carried out on discrete samples from Hole U1478A and archive-half sections from Holes U1478A-U1478D. SIRM and hard isothermal remanent magnetization (HIRM) measured on discrete samples largely follow downcore patterns in magnetic susceptibility. The $S$-ratio is mostly stable; however, distinct minima at $\sim 90,165$, and $245 \mathrm{~m}$ CSF-A indicate a strong depletion of low-coercivity minerals. These intervals coincide with minima in the magnetic susceptibility and SIRM records. The minimum in magnetic susceptibility at $\sim 90 \mathrm{~m}$ CSF-A lies below the sulfate-methane transition, and the minimum at $\sim 165 \mathrm{~m}$ CSF-A is located just below an interval of elevated dissolved Fe and Mn concentrations, suggesting that in these zones early diagenetic processes affected the magnetic mineral record.

Inclination data appear to be of good quality, and the Brunhes/Matuyama boundary and the Jaramillo Subchron were identified. According to biostratigraphy, the sedimentary sequence dates to 4 Ma; however, the Matuyama-Gauss Chron transition was not identified in the paleomagnetic data which might relate to a loss of the paleomagnetic signal because of diagenetic processes.

\section{Stratigraphic correlation}

Four holes were drilled at Site U1478 using the APC and HLAPC. Generally good core quality and clear magnetic susceptibility signals resulted in robust and unambiguous stratigraphic ties between holes. We have high confidence that these holes constitute a nearly complete section spanning the full length of the longest hole (248 m recovered in Hole U1478A), with the exception of one probable gap at $\sim 195 \mathrm{~m}$ CSF-A. The objective of obtaining a complete section was aided by the fact that the magnetic susceptibility from whole-round physical property loggers could be used for realtime correlation in Holes U1478B-U1478D; adjustments to the drilling depth were made in these holes for the purpose of avoiding potential core gap alignment. A continuous splice was constructed for the uppermost $200 \mathrm{~m}$ CCSF-D, and a floating splice of another $\sim 50 \mathrm{~m}$ of section is appended below the coring gap. In general, the clarity of the stratigraphic ties and the multiple cross-checks from several different data sets gives us high confidence in the integrity of these two separate spliced sequences.

\section{Geochemistry}

Interstitial water chemistry and headspace gas concentrations show relatively intense early sediment diagenesis at Site U1478. The sulfate-methane transition zone occurs at $\sim 70 \mathrm{~m}$ CSF-A, below which sulfate is completely consumed and methane concentrations increase rapidly. Several methane peaks occur below the sulfatemethane transition, with the largest of $\sim 65,000 \mathrm{ppmv}$ at $\sim 214 \mathrm{~m}$ CSF-A. Other redox-sensitive elements, including iron and manganese, also show multiple peaks at depth. These pulses of iron and manganese and associated lows in magnetic susceptibility are interpreted as paleoredox horizons related to repeated fluctuations in sedimentation. Detrital material is the dominant sedimentary component. Carbonate contents average $28 \mathrm{wt} \%$, and TOC contents average $0.5 \mathrm{wt} \%$; neither show any trend with depth.

\section{Site U1479}

Site U1479 is located on a $30 \mathrm{~km}$ wide morphological high, rising $\sim 200 \mathrm{~m}$ above the regional seafloor, on the mid-to-lower western slope of the Agulhas Bank in Cape Basin $\left(35^{\circ} 03.53^{\prime} \mathrm{S}\right.$; $\left.17^{\circ} 24.06^{\prime} \mathrm{E}\right), \sim 85 \mathrm{nmi}$ southwest of Cape Town, South Africa, at a water depth of $2615 \mathrm{mbsl}$.

This region has been the focus of numerous oceanographic studies and a growing number of paleoceanographic studies (e.g., Beal et al., 2011, and references therein) in order to describe the present hydrography within the so-called Indian-Atlantic Ocean gateway (or "Agulhas ring corridor"; Gordon, 2003) and also to gain a better understanding of past oceanographic variations in the area and how they may be related with global climate changes. Several studies have highlighted the Agulhas Current's sensitivity to climate changes and reorganizations of atmosphere and the ocean circulation at large.

As the Agulhas Current detaches from the Agulhas Bank at the southern tip of Africa, it retroflects, shedding rings, eddies, and filaments to the South Atlantic. This leads to leakage of between 2 and $20 \mathrm{~Sv}$ of Indian Ocean water into the Atlantic Ocean and affects the water column to depths of 2000 mbsl (Gordon et al., 1987; de Ruijter et al., 1999a; Richardson, 2007).

The Agulhas ring corridor is an area in which retrieval of highquality sediment cores is difficult. The vigorous Agulhas Current and its variability can cause sediment redistribution because meanders and eddies frequently reach the seafloor. However, a number of published studies and emerging work demonstrate that paleoceanographic records of excellent quality are in fact achievable for reconstructing both surface and deep-water variability in the region (e.g., Rau et al., 2002, 2006; Peeters et al., 2004; Dickson et al., 2010; Martínez-Méndez et al., 2010; Caley et al., 2011, 2012, 2014; Marino et al., 2013; Dyez et al., 2014; Petrick et al., 2015).

The Site U1479 primary objectives are to

- Recover a complete Pliocene-Pleistocene sedimentary succession, including the early Pliocene warm period, mid-Pliocene expansion of Northern Hemisphere ice sheets, and the MPT, from a high-accumulation site located within the Agulhas ring corridor;

- Reconstruct Agulhas Current warm-water transports during orbitally modulated and suborbitally accelerated climatic changes;

- Assess the linking between Antarctic climate variations, circumpolar ocean front instability, and connections with Agulhas leakage into the South Atlantic Ocean;

- Assess the vigor and hydrography of NADW, or its precursors, exported to CDW and the southwest Indian Ocean; and

- Evaluate the possibility of advective salinity feedbacks between Agulhas leakage and AMOC variability, notably the possible role of the leakage in modulating surface-to-deep ocean coupling in the North Atlantic during the transition between climatic states.

Site U1479 consisted of nine holes, ranging in depth from 1.0 to $300.7 \mathrm{~m}$ DSF. Overall, 105 cores were recorded for the site. A total of $963.08 \mathrm{~m}$ of core over a $975.3 \mathrm{~m}$ interval was recovered using the APC system ( $99 \%$ core recovery). Seven intervals were advanced 
without coring over $175.7 \mathrm{~m}$. The total time spent at Site U1479 was 6.0 days.

\section{Sedimentology}

Sediment at Site U1479 consists of one lithologic unit. Unit I (0$301.03 \mathrm{~m} \mathrm{CSF-A)} \mathrm{is} \mathrm{composed} \mathrm{of} \mathrm{light} \mathrm{greenish} \mathrm{gray,} \mathrm{greenish} \mathrm{gray,}$ and light olive-gray (5Y 6/2) nannofossil ooze with or without foraminifers.

Moderate to strong bioturbation is the only secondary sedimentary structure observed and is widespread throughout the sequence. Discrete ichnofossil burrows were commonly observed, often surrounded by thin darker bands. The occurrence of intervals rich in sand-sized quartz and foraminifers further suggests the deposition of contourites and/or turbidites.

\section{Physical properties}

All high-resolution physical property records derived by core logging show similar cyclic changes that are likely related to alternations within the nannofossil ooze between intervals of more or less terrigenous content and thus may reflect changes in ocean circulation and/or terrigenous supply. Generally, the changes in physical properties trends broadly correlate between the parameters. A slump in the lowermost part of Site U1479 is characterized by physical properties that are distinctly different from the rest of the cored section.

\section{Micropaleontology}

Biostratigraphy of calcareous nannofossils, planktonic foraminifers, and diatoms indicates that Hole U1479B spans the Late Pleistocene to the late Miocene with a bottom age of $\sim 7 \mathrm{Ma}$. Calcareous microfossils include primarily subtropical convergence and coastalto slope-water taxa with minor abundances of warm subtropical and subpolar taxa. Diatoms are mostly composed of subtropical taxa with a minor presence of Southern Ocean taxa in the Pleistocene. Planktonic foraminifers and calcareous nannofossils are abundant throughout Site U1479, whereas diatoms make episodic appearances, particularly in the upper and lower parts of the record. Preservation is good to moderate for calcareous taxa and moderate to poor for diatoms. The biochronology for both calcareous microfossil groups and diatoms is consistent with an average sedimentation rate of $\sim 4.9 \mathrm{~cm} / \mathrm{ky}$.

\section{Paleomagnetism}

Paleomagnetic analyses were carried out on archive halves from Site U1479 and on discrete samples from Hole U1479B. The inclination and declination data from the archive halves are relatively noisy, which might be partially explained by (1) high dilution by carbonate and (2) the alteration of magnetic minerals as suggested by downhole records of various rock magnetic parameters including the $S$-ratio, HIRM, SIRM, and magnetic susceptibility. Inclinations and declinations show an interval of normal polarity in the uppermost 55 m CSF-A (Brunhes Chron), although the lower boundary is deeper than would be anticipated from the biostratigraphy. A distinct interval of reversed polarity between $\sim 55$ and $\sim 125$ m CSF-A corresponds probably to the Matuyama Chron, which spans from $\sim 2.6$ to 3.6 Ma. Unlike the Brunhes/Matuyama Chron boundary, the inferred Matuyama/Gauss Chron boundary is in agreement with ages derived from the biostratigraphy. Additional shore-based paleomagnetic analyses on rock magnetic properties and directional data are necessary to refine the magnetostratigraphy for Site U1479.

\section{Stratigraphic correlation}

Stratigraphic correlation of Holes U1479B-U1479I was complicated by very low magnetic susceptibility and adverse weather conditions resulting in several partial core recoveries in all the holes, as well as soupy top sections that were generally unusable for stratigraphy. Notwithstanding, the NGR and color (e.g., RGB green) records display clear variability in all undisturbed core sections, making the alignment of cores relatively straightforward once all scanning was complete. Furthermore, comparatively constant offsets between cores in Holes U1479B and U1479C led to the development of a robust and nearly complete splice from just below the mudline to the bottom of Hole U1479B at $\sim 300$ m CSF-A. The generally clear stratigraphic relationship between Holes U1479B and U1479C only needed refinement and supplementation in scattered discrete intervals.

\section{Geochemistry}

Interstitial water chemistry and headspace gas concentrations indicate moderate early sediment diagenesis. Major element concentrations show some evidence of incorporation into clay minerals and precipitation of authigenic carbonates. There is no clear sulfate-methane transition zone in Hole U1479B-sulfate concentrations are zero at $\sim 185 \mathrm{~m} \mathrm{CSF}-\mathrm{A}$, but methane concentrations are never above $\sim 50$ ppmv. Other redox-sensitive elements, such as iron and barium, show more dramatic enrichments, with iron reaching $\sim 15 \mu \mathrm{M}$ at $\sim 60 \mathrm{~m}$ CSF-A and barium reaching $\sim 600 \mu \mathrm{M}$ at $\sim 150$ m CSF-A. Calcium carbonate ranges from $\sim 51$ to $91 \mathrm{wt} \%$, with an average value of $67 \mathrm{wt} \%$ and no distinct trend downhole. Organic carbon ranges between 0.15 and $1.93 \mathrm{wt} \%$ with an average value of $0.62 \mathrm{wt} \%$.

\section{Expedition synthesis and preliminary scientific assessment}

The greater Agulhas Current system is a key location to study past ocean circulation and climate, as it represents a significant component of the global thermohaline circulation, carrying surface water into the Atlantic Ocean that compensates for the export of deep water from the Atlantic Basin to the world ocean (Figure F1). The Agulhas Current marks the western boundary of the South Indian Ocean subtropical gyre where it flows southwards along the southeastern African continental margin. At the southern tip of South Africa the Agulhas Current, under its own inertia, separates from the margin and retroflects back into the Indian Ocean flowing as the ARC. During the retroflection the Agulhas current periodically sheds large (up to $400 \mathrm{~km}$ ) mesoscale anticyclonic Agulhas rings (Figure F2), which represent a significant pathway for warm and high-salinity water transfer from the Indian Ocean into the South Atlantic Ocean. Modulation of this so-called "Agulhas leakage" variably impacts the buoyancy structure there and also likely contributes to mode changes and variability of the AMOC and thus climate variability in the North Atlantic region and beyond. Additionally, variations in Agulhas warm-water transports along the southeast African continental margin foster exchanges of heat and moisture with the atmosphere that influence regional climates in southern Africa.

Operations during Expedition 361 drilled six sites in the IndianAtlantic Ocean gateway in February and March 2016 (Figure F3). In total, we recovered $5175 \mathrm{~m}$ of core, with an average recovery of $102 \%$, during 29.7 days of on-site operations, from a region poorly 
represented previously in the database of drill sites for scientific purposes. No holes were logged. This is considerably less than the initially planned campaign targeting $5811 \mathrm{~m}$ of section, including downhole logging at four sites (Hall et al., 2015). The difference amounts to $\sim 11$ days of lost operational time. A medical evacuation accounted for 1.8 days and weather a further 1.5 days of lost operations. The remainder of the lost operational time was due to delays in attaining the necessary permissions to operate in Mozambique's exclusive economic zone (EEZ) waters, which necessitated a revision of the drilling plan and $2840 \mathrm{nmi}$ of additional transit to Expedition 361.

Expedition 361 South African Climates (Agulhas LGM Density Profile) had the following five fundamental objectives:

- To establish the sensitivity of the Agulhas Current to changing climates of the Pliocene-Pleistocene in association with transient to long-term changes of high-latitude climates, ocean gateways, tropical heat budgets, and the monsoon system;

- To determine the dynamics of the Indian-Atlantic Ocean gateway circulation during such climate changes in association with changing wind fields and migrating ocean fronts;

- To examine the connection between Agulhas leakage and ensuing buoyancy transfer and shifts of the AMOC during major ocean and climate reorganizations during at least the last $5 \mathrm{My}$;

- To address the impact of Agulhas variability on southern Africa terrestrial climates and, notably, rainfall patterns and river runoff; and

- To constrain the temperature, salinity, and density structure of the LGM deep ocean from the bottom of the ocean to the base of the main thermocline.

The expedition made major strides toward fulfilling each of these objectives. The recovered sequences allowed complete spliced sections to be generated that span the interval of 0 to between $\sim 0.13$ and $7 \mathrm{Ma}$ (Figure F11). The sedimentary compositions (Figure F12) range from highly terrigenous near the Zambezi (Site U1477) and Limpopo (Site U1478) Rivers and in the Natal Valley (Site U1474) to very carbonate rich in the northern Mozambique Channel (Site U1476), the Agulhas Plateau (Site U1475), and Cape Basin (Site U1479). The carbonate fossil preservation is good in the Pleistocene and mostly good to moderate, tending to be a little worse near the bottom of each sequence (Figures F13, F14). A robust biostratigraphy was developed for each Site using nannofossils and foraminifers (Figures F15, F16). At Sites U1475 and U1479, diatoms are abundant enough to provide further biostratigraphic constraints, and at these sites there is potential for future paleoenvironmental work with diatoms (Figure F17). All the fossils showed a mixture of tropical and subtropical convergence and temperate or subpolar species in the southernmost sites (Figures F17, F18, F19).Changes in these assemblages through time will provide important constraints on the dynamics of the Agulhas Current system.

For Sites U1475, U1476, U1478, and U1479, sea conditions and time were sufficient that geochemical compositions were measured on a suite of solid bulk samples from the carbonate sample residue. $\mathrm{As} \mathrm{Ba} / \mathrm{Al}$ ratios may be a good $\mathrm{X}$-ray fluorescence proxy for productivity, Figure F20 displays the $\mathrm{Ba} / \mathrm{Al}$ ratios of bulk samples against TOC. Site U1477, with an extremely high terrigenous load, shows no correlation and has $\mathrm{Ba} / \mathrm{Al}$ ratios of typical silicate detritus. Site $\mathrm{U} 1478$ also has mostly terrigenous $\mathrm{Ba} / \mathrm{Al}$ ratios, but a few samples stand above. Site U1476 is in an area of low productivity, so the range of $\mathrm{Ba} / \mathrm{Al}$ ratios is low and not correlated with TOC. However,
Figure F11. Age-depth relationships, Sites U1474-U1479. A. Time estimates based on a combination of major planktonic foraminifer, calcareous nannoplankton, diatom, and paleomagnetic datums. B. Implied sedimentation rates.
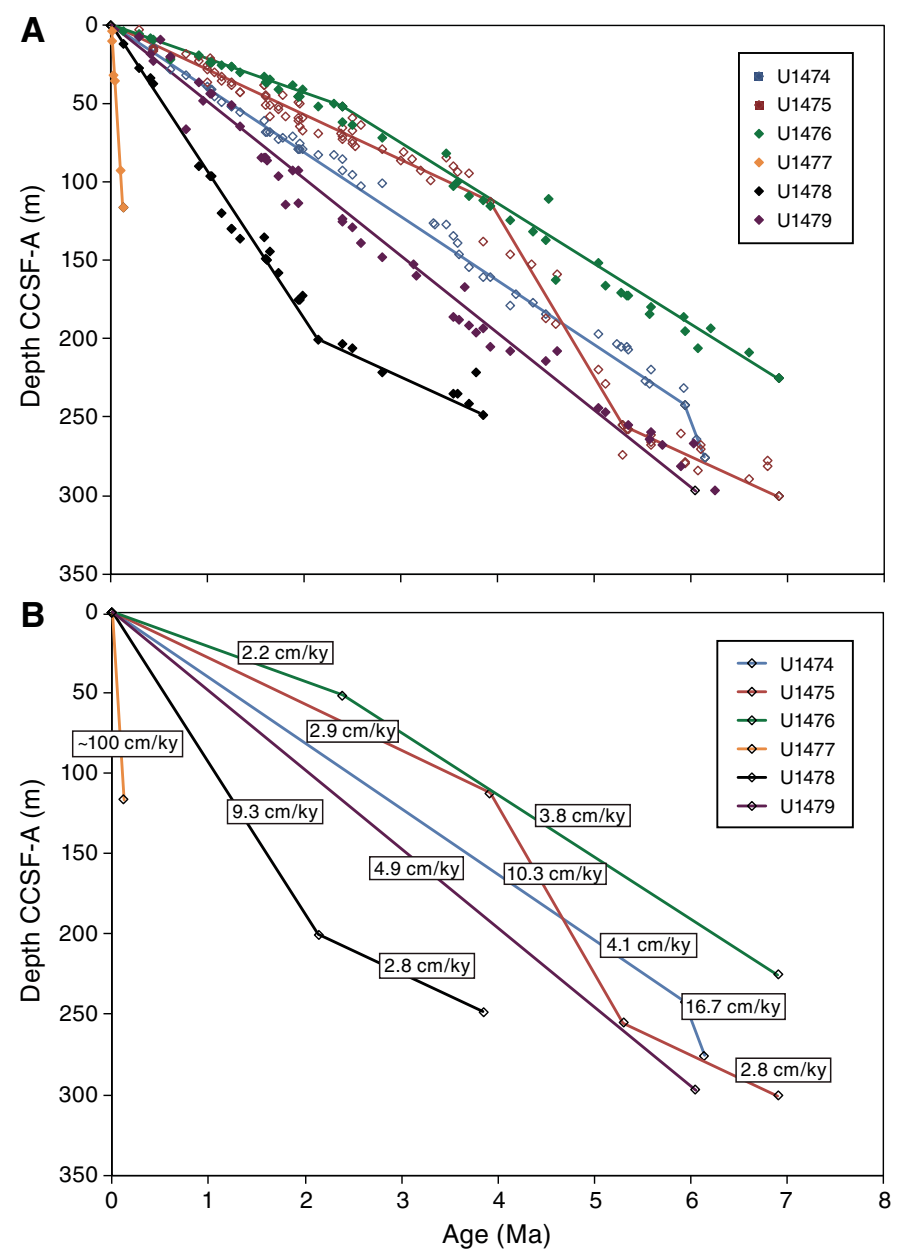

it is elevated above terrigenous, indicating at least $50 \%$ of the $\mathrm{Ba}$ is probably from biogenic sources. Site U1475, located on the Agulhas Plateau where we would expect variations with the position of the $\mathrm{STF}$, has high $\mathrm{Ba} / \mathrm{Al}$ ratios and has a generally strong positive trend with TOC with the exception of a couple of samples.

Early sediment diagenesis, driven by microbial respiration of organic matter in sediment, defines many dissolved elemental profiles. One of the characteristic profiles that indicates the extent and intensity of these reactions is dissolved sulfate (Figure F21). Where microbial respiration is intense as a result organic matter availability sulfate is rapidly consumed. Where microbial respiration is more moderate sulfate decreases more gradually and sometimes persists to the base of the measured interval. We see a range of diagenetic intensities across the Expedition 361 sites, with the most intense microbial activity and diagenesis at Site U1477 (Zambezi) and the least activity at Site U1476 (Mozambique Channel). It is likely that the observed differences between sites are driven by location and sedimentation rate rather than organic carbon content because TOC does not vary systematically between sites (Figure F20).

Operations at Site U1474 (Natal Valley; Figure F3) were scheduled to produce three APC/XCB holes to 300 meters below seafloor (mbsf), with logging in one of the deep holes and a single hole to 
Figure F12. Summary of major lithologic characteristics of sediment cores, Sites U1474-U1479. Sites U1474, U1477, and U1478 are characterized by terrigenous sedimentation with carbonate content between 5 and 37.5 wt\%. Sites U1475, U1476, and U1479 are characterized by pelagic sedimentation with carbonate content between 58 and $80 \mathrm{wt} \%$. Sediment color ranges from white-gray (Site U1475) to greenish gray (Sites U1474, U1476, and U1479) and dark gray (Sites U1477 and U1478). Slight to moderate bioturbation occurs at Sites U1476-U1478, whereas strong bioturbation marks the sediment at Sites U1474, U1475, and U1479. Sandy layers $(\sim 0.5 \mathrm{~cm}$ to $\sim 2$ $\mathrm{m}$ thick) at Sites U1474, U1478, and U1479 are interpreted as contourite and/or turbidite deposits.

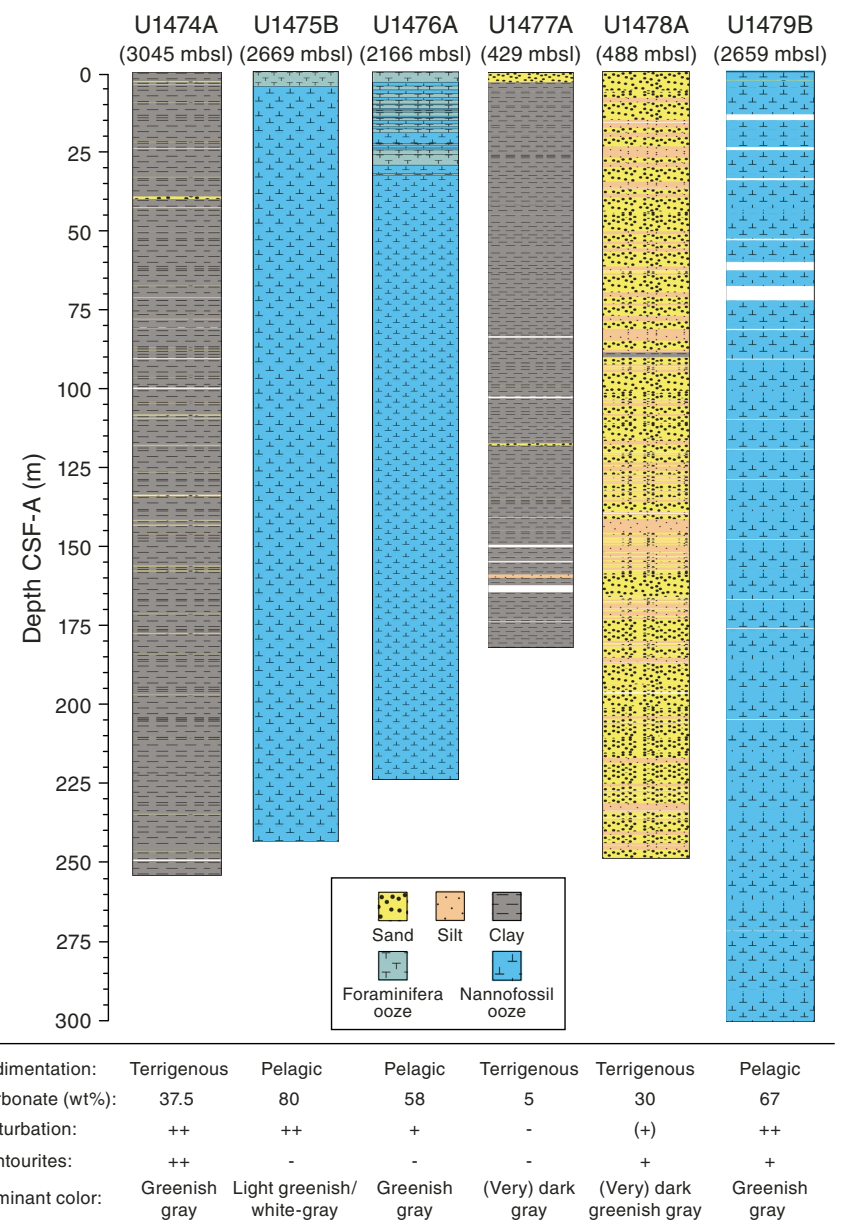

150 mbsf for interstitial water samples. This drilling objective was largely accomplished with the exception of logging and a reduction in the target section depth to $254 \mathrm{~m} \mathrm{CSF}$-A because of loss of operational time as noted above. Recovery was excellent, and triple-coring allowed compilation of a complete spliced record extending to the latest Miocene ( 6.2 Ma). The site boasts an excellent paleomagnetic timescale (Figure F22) that is in good agreement with the biostratigraphy, and these together suggest uniform sedimentation rates of $\sim 4.1 \mathrm{~cm} / \mathrm{ky}$ over most of the sequence with an apparent increase near the bottom (Figure F11). This is the only site situated beneath the main flow of the fully constituted Agulhas Current and will therefore provide the opportunity for high-resolution climate reconstructions of Agulhas Current warm-water transports and upstream variability that may allow the identification of connections between Agulhas leakage and its headwater variability. The site also holds significant potential to investigate the connections between southern African terrestrial climates and southeast Indian Ocean heat budgets and notably the links to the cultural evolution of early modern humans. A high-resolution program of interstitial water samples, collected from a 150 m CSF-A section, will provide an additional data point to the presently available pore water LGM temperature and salinity inventory.

Operations at Site U1475 (Agulhas Plateau; Figure F3) were scheduled for three APC/XCB holes to 300 mbsf with logging and a single hole to $150 \mathrm{mbsf}$ for interstitial water samples. This drilling objective was largely accomplished with the exception of logging. Recovery was excellent, and multiple coring, including some spot coring needed because of weather-related disturbances, allowed recovery of a complete spliced record extending to the late Miocene ( $\sim \mathrm{Ma}$ ). The paleomagnetic timescale is robust to the base of the Mammoth Chron (C2An.2r at 99 m CCSF-A) (Figure F22) and is in good agreement with the biostratigraphy, but the signal was too weak to allow a paleomagnetic timescale to be extended to the bottom based on shipboard data. Biostratigraphic estimates suggest sedimentation rates of $\sim 2.9 \mathrm{~cm} / \mathrm{ky}$ in the uppermost $115 \mathrm{~m}$ CCSF-

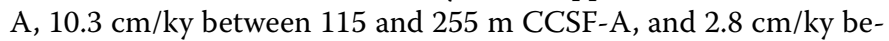
tween 255 m CCSF-A and the bottom of the section (Figure F11). This record will provide the opportunity for high-resolution climate reconstructions of the ARC and connections with the STF, productivity, and deep-water circulation. A high-resolution program of interstitial water samples, collected from a $150 \mathrm{~m}$ CSF-A section, will provide an additional data point to the presently available interstitial water LGM temperature and salinity inventory.

Operations at Site U1476 (Mozambique Channel; Figure F3) were scheduled for three APC/XCB holes to $300 \mathrm{mbsf}$ with logging and a single hole to $150 \mathrm{mbsf}$ for interstitial water samples. This drilling objective was largely accomplished with the exception of logging and a reduction in the target depth to $220 \mathrm{~m}$ CSF-A because of loss of operational time as noted above. Recovery was excellent, and triple coring allowed recovery of a complete spliced record extending to the late Miocene ( 6.9 Ma). The site boasts excellent biostratigraphy and notably cyclic physical properties. The paleomagnetic reversal signal was complicated by apparent cyclically varying magnetic mineralogy, strong coring overprints and operational issues with the orientation tool. Shore-based work will be required to try to extract a paleomagnetic timescale at this site (Figure F22). The sedimentation rate based on biostratigraphy is $\sim 2.2$ $\mathrm{cm} / \mathrm{ky}$ from the mudline to $\sim 50 \mathrm{~m} \mathrm{CCSF}-\mathrm{A}$ and $3.8 \mathrm{~cm} / \mathrm{ky}$ from $\sim 50$ $\mathrm{m}$ CCSF-A to the bottom (Figure F11). This site is located on Davie Ridge at the northern end of the Mozambique Channel, in a region with low productivity and a mean annual sea-air $\mathrm{CO}_{2}$ flux is close to zero (Takahashi et al. 2009). The site will therefore provide the opportunity for high-resolution reconstructions of tropical faunal assemblages is promising for the identification of connections between Agulhas leakage and its headwater variability. The site also holds significant potential to investigate the connections between southern African terrestrial climates and southeast Indian Ocean heat budgets and thermocline and deep-water variability with likely links to the development of the Indonesian Throughflow as well as aridification of east Africa. Foraminifers show excellent preservation, thus also making this an ideal site for a long record of surfaceocean $\mathrm{pH}$ from boron isotopes. A high-resolution program of interstitial water samples collected from a $150 \mathrm{~m}$ CSF-A section will provide an additional data point to the presently available interstitial water LGM temperature and salinity inventory.

Operations at Site U1477 (Zambezi Catchment; Figure F3) were scheduled for three APC/XCB holes to 207 mbsf. This drilling objective was modified to end at APC refusal, which led to recovering $\sim 166 \mathrm{~m}$. Recovery was excellent, and triple coring allowed compila- 
Figure F13. Summary of calcareous nannofossil preservation and reworking at Expedition 361 drill sites for the Pleistocene, Pliocene, and Miocene. Nannofossil preservation score is based on ratings of good, moderate, and poor to illustrate changes in preservation through time. Qualitative percentages of nannofossil group (red) and reworked species (green) abundances are indicated on the right with relative latitudinal and longitudinal coordinates for each site. Missing green charts from different time periods are due to the negligible number of reworked species. Site U1477 sequence covers only the Pleistocene; reworked species are sparsely recorded and it is the only site where nannofossil abundance is variable. The rest of the sites are characterized by a total abundance of calcareous nannofossils $>80 \%$ of sediment particles within the three time intervals.

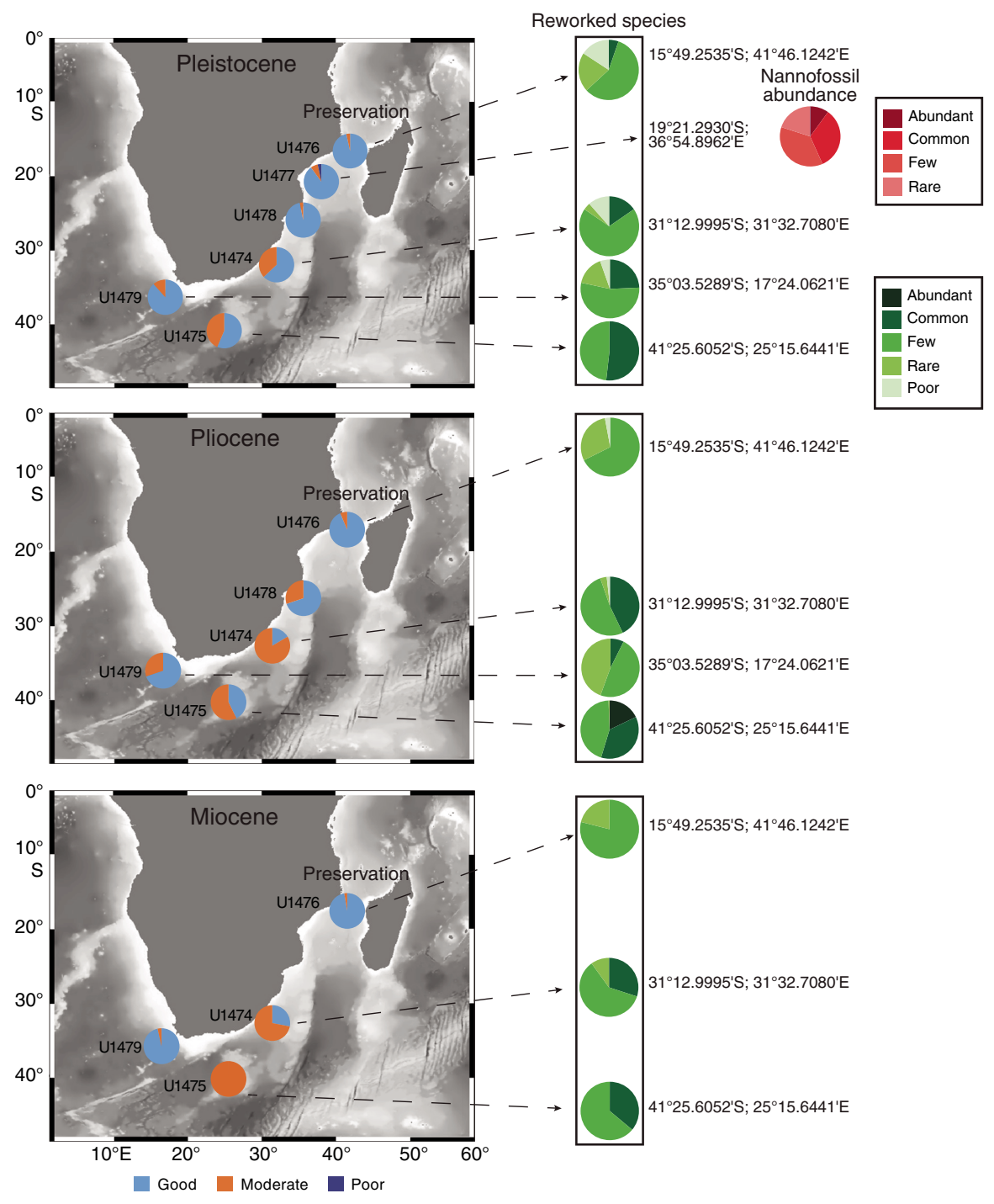

tion of a complete spliced record to $\sim 85 \mathrm{~m} \mathrm{CCSF}$-A. The magnetic susceptibility signal is strong and could be matched to nearby ${ }^{14} \mathrm{C}$ dated cores, and two biostratigraphic markers, in agreement, pointed to sediment accumulation rates of $\sim 1 \mathrm{~m} / \mathrm{ky}$ at this site (Figure F11). This extreme accumulation rate was a complete surprise and led to only recovering $\sim 120 \mathrm{ky}$ of sediment record from the Zambezi Catchment. Therefore, the sediment sequence does not provide 2 My record as planned, but will instead provide the opportunity for extremely high resolution reconstructions of, for example, terrestrial climate and thermocline characteristics during the last glacial cycle. The site also holds significant potential to investigate the connections between southern African terrestrial climates and southeast Indian Ocean heat budgets and the links to the cultural evolution of modern humans.

Operations at Site U1478 (Limpopo Catchment; Figure F3) were scheduled to be three APC/XCB holes to $180 \mathrm{mbsf}$, with a permitted depth to $250 \mathrm{mbsf}$, and a single hole to $150 \mathrm{mbsf}$ for interstitial waters. This drilling objective was successfully accomplished, and coring was taken to the maximum allowed depth of $250 \mathrm{~m}$ CSF-A with APC, until refusal, followed by HLAPC coring. Recovery was excellent, and triple coring allowed compilation of a complete spliced record extending to $\sim 4 \mathrm{Ma}$. The paleomagnetic timescale was robust for the uppermost $\sim 100$ m CSF-A, below which the signal appears to be modified by diagenesis (Figure F22). For the upper part, the magnetic reversal positions are in good agreement with the biostratigraphy, and these together suggest a sedimentation rate of $\sim 9.3 \mathrm{~cm} / \mathrm{ky}$ from the mudline to $\sim 200 \mathrm{~m}$ CCSF-A and rate of 2.8 $\mathrm{cm} / \mathrm{ky}$ from $\sim 200 \mathrm{~m}$ CSF-A to the bottom of the site (Figure F11). This record will provide the opportunity for high-resolution climate reconstructions of faunal, biogeochemical, and terrigenous tracers that are characteristic for the upper reaches of the Agulhas Current warm-water transports that will allow connections between Agulhas leakage and its headwater variability. The site also holds significant potential to investigate the connections between southern 
Figure F14. Summary of planktonic foraminifer preservation from Sites U1474-U1479 through time. Qualitative preservation ratings were tracked through four time intervals: the Pleistocene, late Pliocene, middle Pliocene, and early Pliocene. Foraminifer preservation score is based on ratings of good, moderate, and poor to illustrate changes in preservation through time.
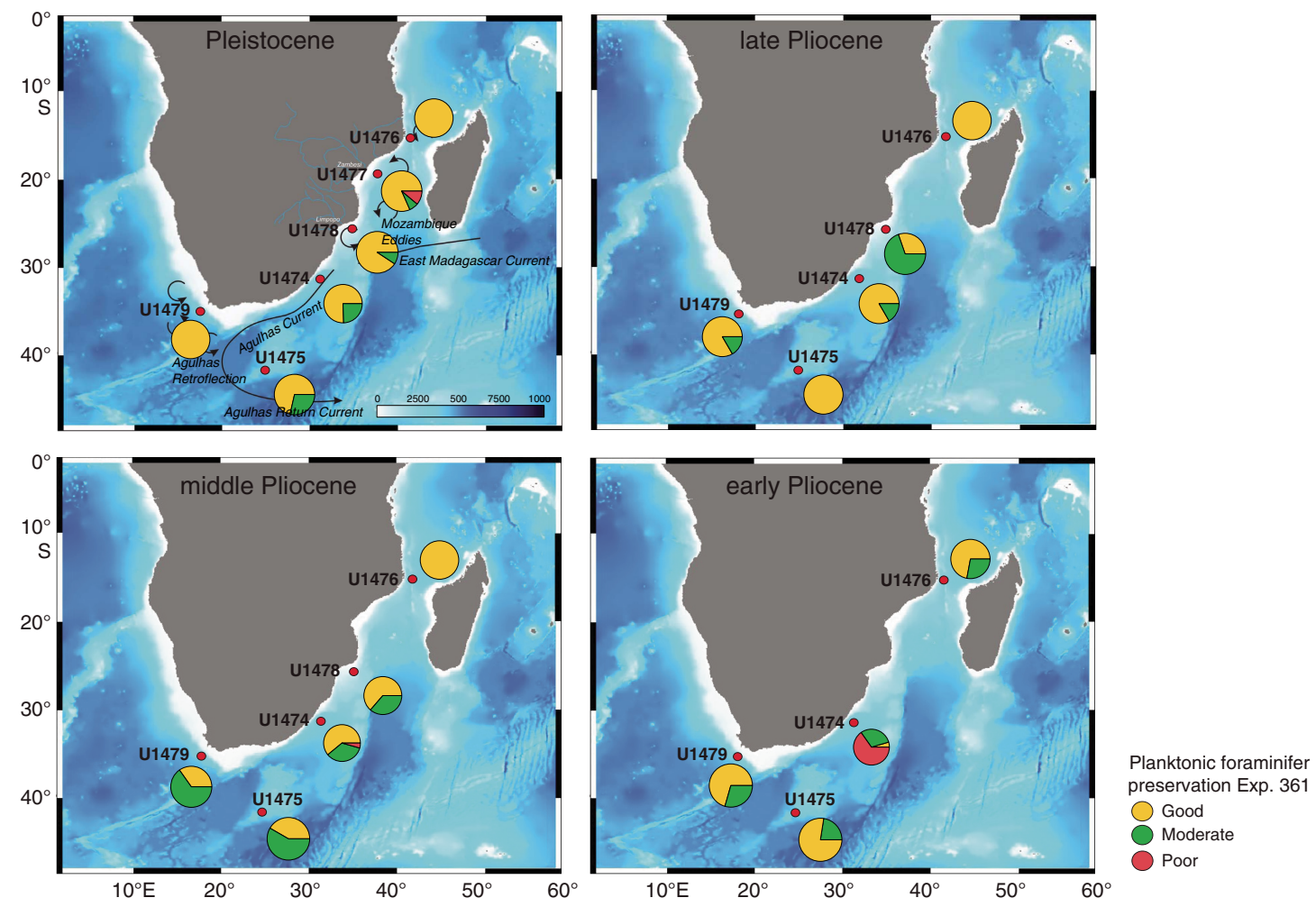

African terrestrial climates and southeast Indian Ocean heat budgets and links to the cultural evolution of early modern humans. A high-resolution program of interstitial water samples collected from a $150 \mathrm{~m}$ CSF-A section will provide an additional data point to the presently available interstitial water LGM temperature and salinity inventory.

Operations at Site U1479 (Cape Basin; Figure F3) were scheduled for three APC/XCB holes to $350 \mathrm{mbsf}$ with logging. This drilling objective was largely accomplished with the exception of logging and a reduction in the target section depth to $\sim 300 \mathrm{~m} \mathrm{CSF-A} \mathrm{be-}$ cause of time and sea condition constraints and the biostratigraphy indication that we had achieved the target age. Recovery was excellent, and multiple coring (with extra cores taken because of disturbed intervals related to large ocean swells) allowed compilation of a complete spliced record extending to $\sim 7 \mathrm{Ma}$. Although the signal is weak and therefore will need future work on shore, the paleomagnetic timescale (Figure F22) is in good agreement with the biostratigraphy, and these together suggest uniform sedimentation rates of $\sim 4.3 \mathrm{~cm} / \mathrm{ky}$ through the sequence (Figure F11). This record represents the only site situated in the immediate Agulhas leakage pathway. It will therefore provide the opportunity for high-resolution climate reconstructions of the leakage and temporal comparisons with deep-water circulation.

The following specific scientific objectives of the expedition are expected to be readably achievable with the materials recovered:

- To determine the variability of the greater Agulhas Current system under contrasting climatic regimes: early Pliocene warm conditions, during the mid-Pliocene expansion of Northern Hemisphere ice sheets, and through the MPT;
- To establish the role of Agulhas leakage in transient and longterm shifts of the AMOC during these climatic transitions: proxy records of mode/strength of Agulhas leakage during periods of major climatic reorganizations and for AMOC variations through the same intervals;

- To establish the response of the Agulhas Current system to Antarctic climate variability and bipolar linkages: evidence for variation of the Agulhas leakage in highly resolved temporal records will be compared to Antarctic and bipolar climate changes as well as with evidence for shifts of Southern Ocean fronts bordering the Agulhas corridor at the southern tip of Africa, and position and strength of the westerly wind belt;

- To understand the remote tropical origins of Agulhas Current variability: evidence for variation of Agulhas leakage in highly resolved temporal records will be compared to records of Indonesian Throughflow and monsoon modulation on the Agulhas Current source region and impacts on warm-water and saltwater transports along the southeast African margin and IndianAtlantic saltwater leakage;

- To better determine southern African climate sensitivity: comparison of varying Agulhas Current warm-water transports with rainfall patterns in southern Africa in connection with the Pliocene-Pleistocene evolution of tropical climates, ITCZ migration, and tectonic history of eastern Africa;

- To provide further verification of glacial-interglacial variations in the Southern Ocean's role in the carbon cycle: nutrient cycling, productivity, and $p \mathrm{CO}_{2}$ and their connections with global biogeochemical cycles. 
Figure F15. Calcareous nannofossil comparative biostratigraphic chart, Sites U1474-U1479.
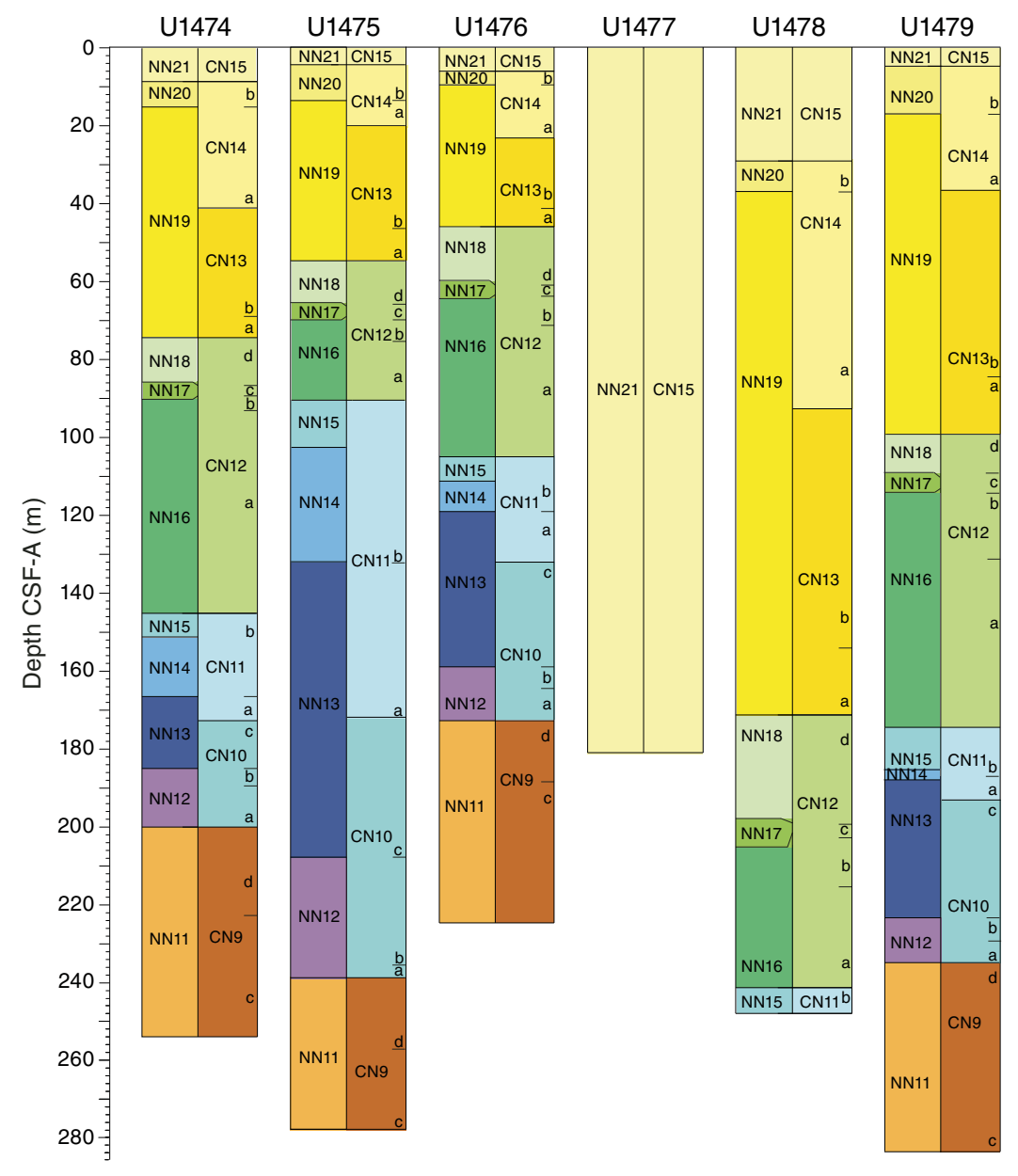

\section{Drilling operations and core handling}

Drilling operations and core handling were performed, as is widely acknowledged for IODP, with total professionalism and with outstanding commitment to achieving the expedition scientific objectives. As a result, materials recovered during Expedition 361 were accordingly astonishing and promise significant future scientific research, including full-recovery APC coring to deeper than $300 \mathrm{~m}$ CSF-A at Site U1479; complete APC records through the late Miocene/early Pliocene to recent at Sites U1474-U1476, U1478, and U1479; and 382 interstitial water samples from Sites U1474U1476 and U1478 to help constrain the temperature, salinity, and density structure of the LGM spanning from 488 to $3045 \mathrm{mbsl}$. At Site U1477, where degassing within the core barrel was pronounced, appropriate core handling adjustments were implemented rapidly, preserving the scientific value of the cored sections. In summary, the exceptional skills of the drillers and core technicians were the main reason why, despite setbacks, the scientific objectives of Expedition 361 could be accomplished.

\section{Critical aspects}

Administrative preparation for operations within Mozambique EEZ waters

The majority of the lost operational time was due to delays in attaining the necessary permissions to operate in Mozambique EEZ waters (received some 48 days after the expedition start). These issues should be addressed and resolved prior to an expedition so as not to impact operational time and thereby jeopardize the scientific impact of the recovered material. Although such issues are relatively rare, in this case Expedition 361 had to compensate by dropping all of the planned logging operations and shortening holes (i.e., exclude $\mathrm{XCB}$ drilling) to ensure complete APC spliced records to target stratigraphic depths. To this end the paleoceanographic objectives and the interstitial water program, in support of the APL (Agulhas LGM Density Profile), were met. Fortunately, smooth coring operations, sequence characteristics, and a clement sea state for much of the expedition worked in our favor to produce $100 \%$ recovery. This will serve to reduce the negative impact of lost operational time. 
Figure F16. Planktonic foraminifer comparative biostratigraphic chart, Sites U1474-U1479.

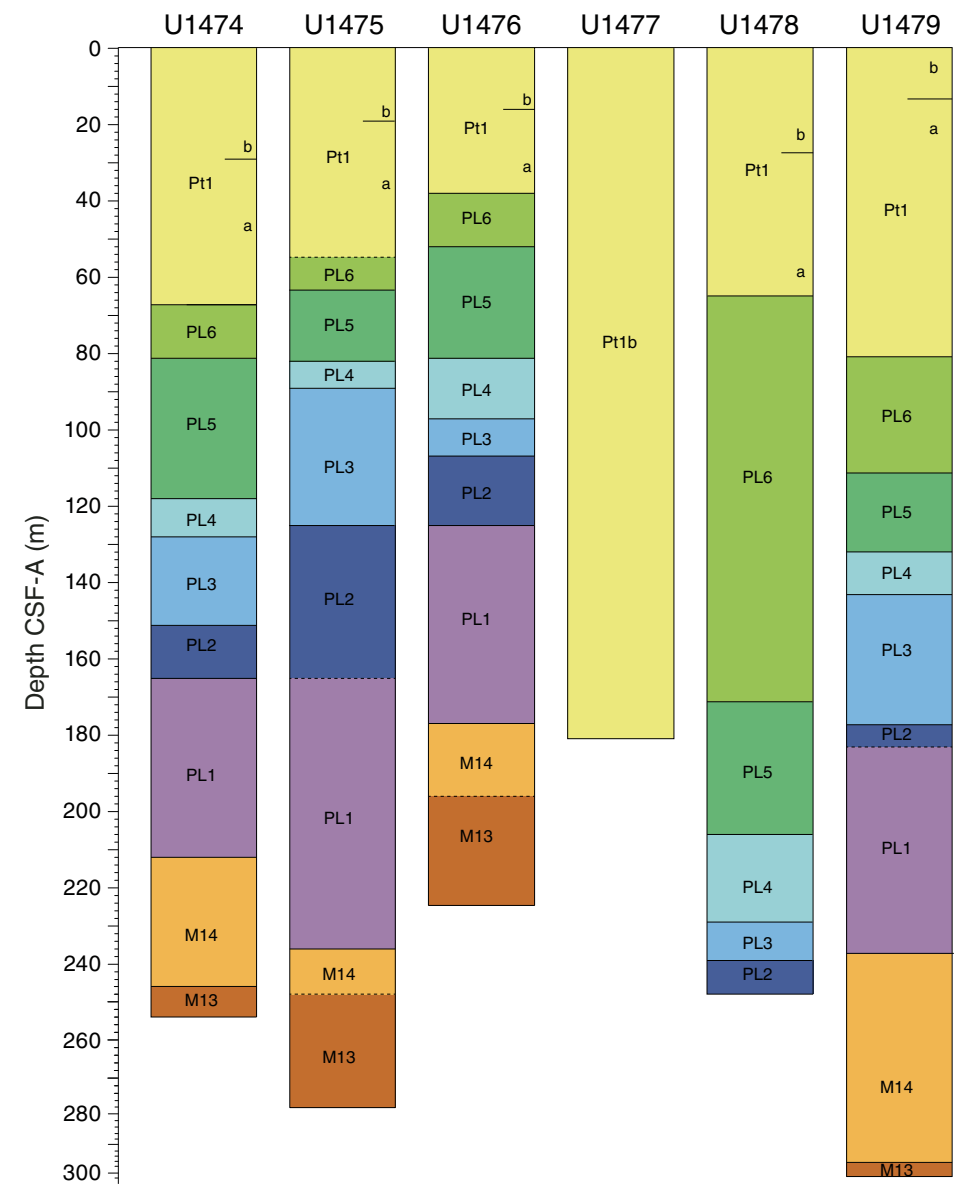

Figure F17. Summary of diatom from Sites U1474-U1479 through time. Qualitative estimated percentages were used to track changes in siliceous microfossil assemblage through time spanning the Holocene to the late Miocene.
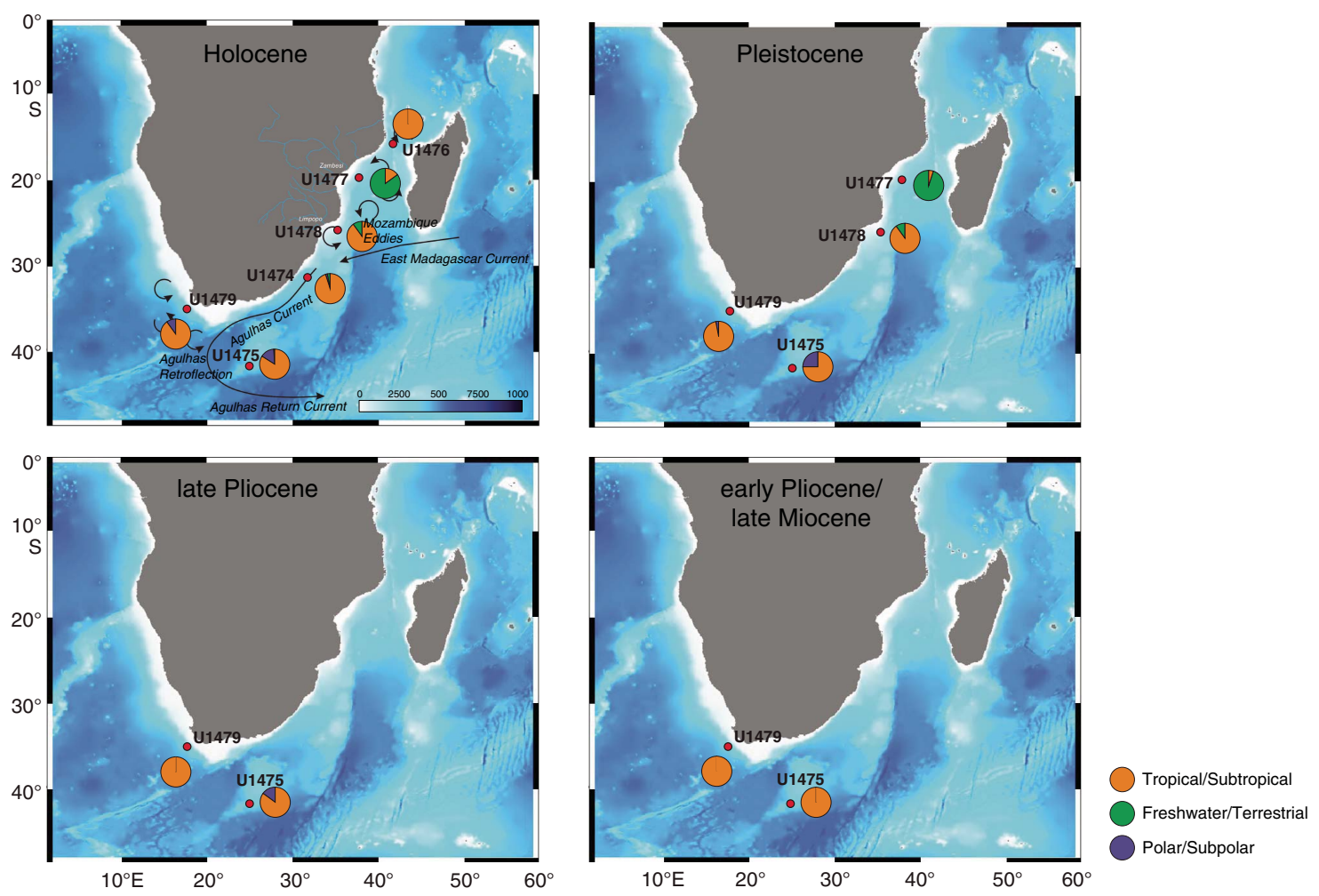
Figure F18. Summary of qualitative estimated percentages of calcareous nannofossil assemblages in sediment recovered from Sites U1474-U1479 spanning the late Miocene to Holocene (mudlines).
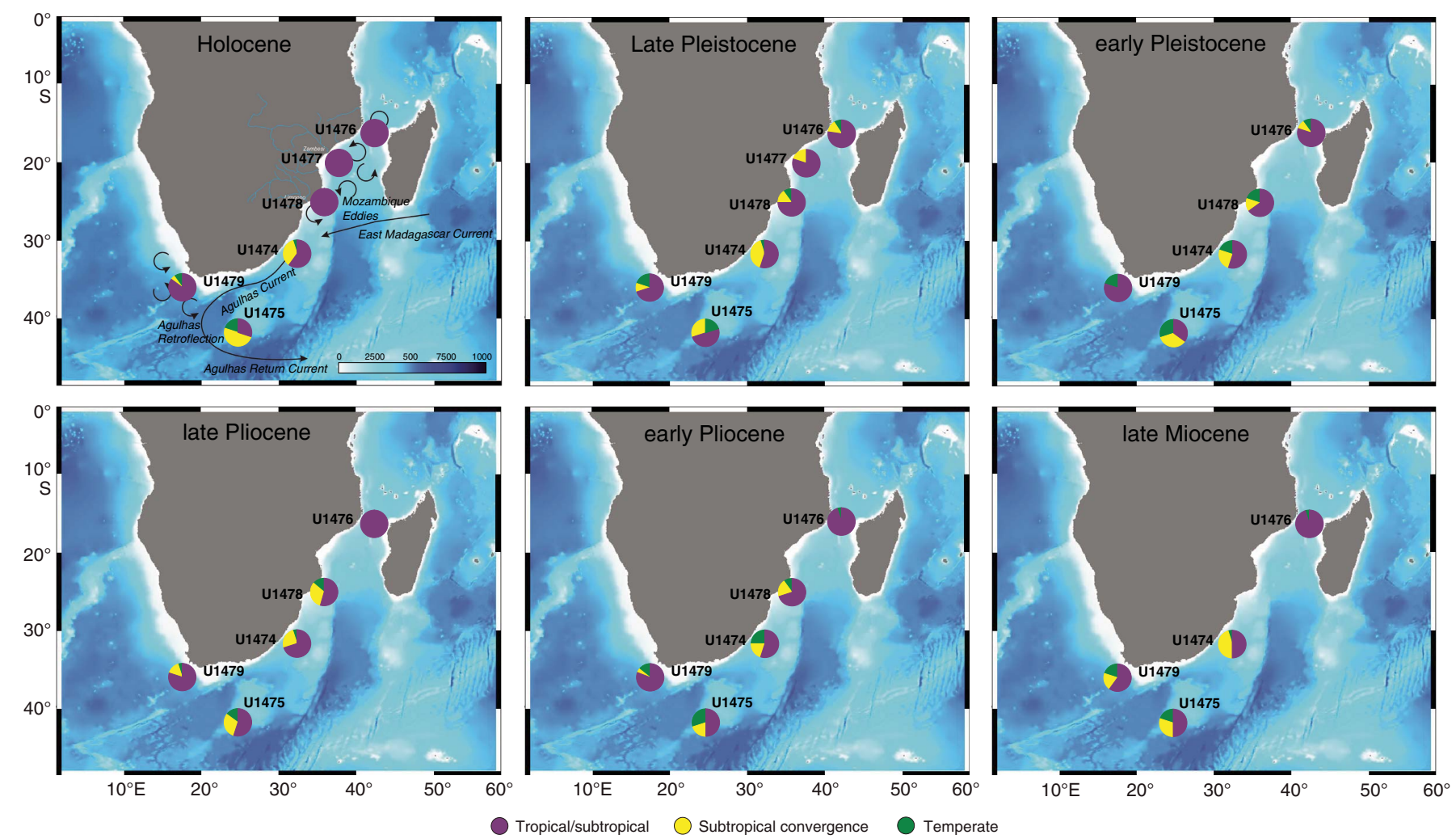

Figure F19. Summary of planktonic foraminifer abundance for Sites U1474-U1479 through time.
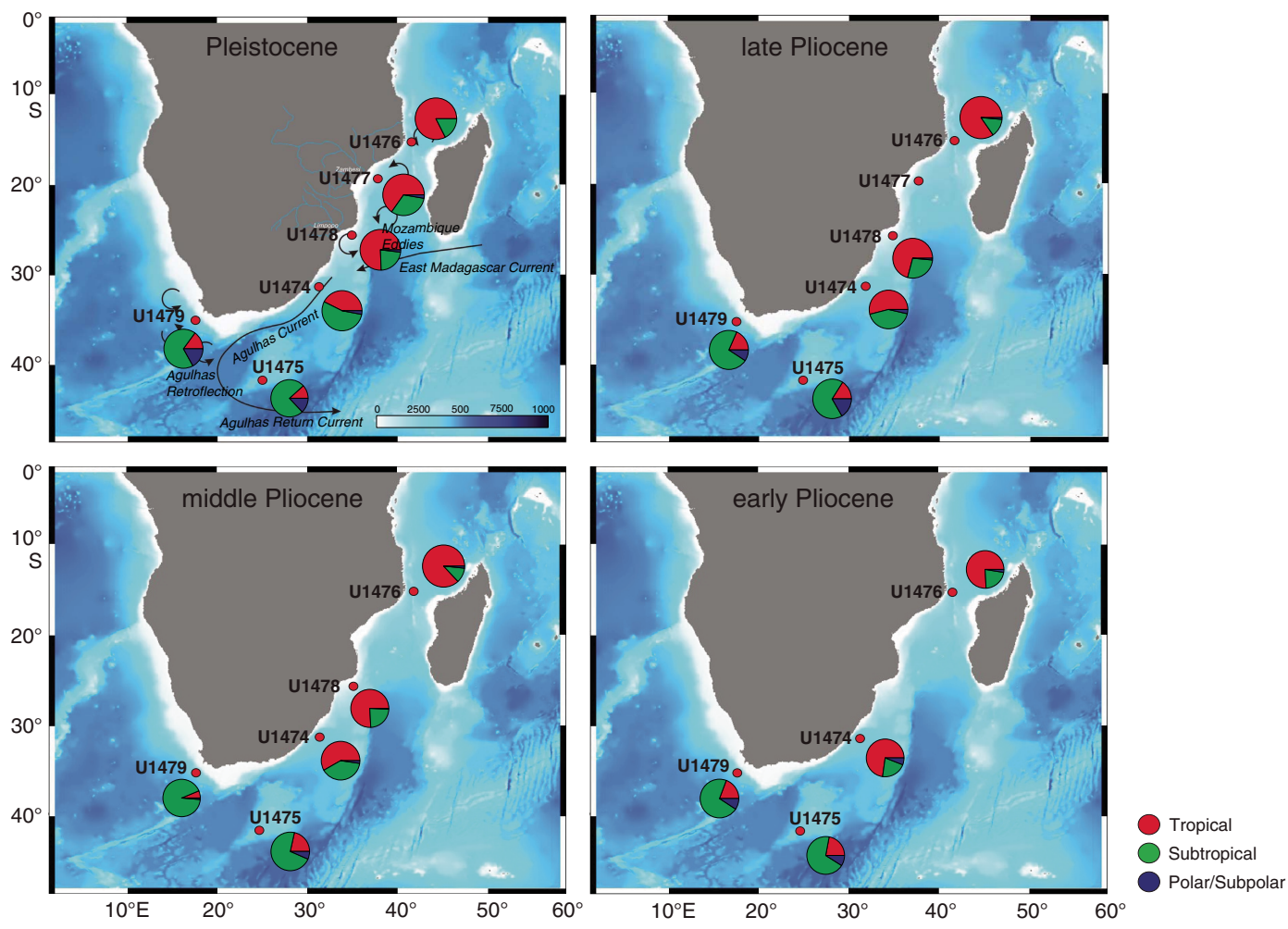
Figure F20. TOC vs. Ba/Al ratio from bulk samples, Sites U1475-U1478.

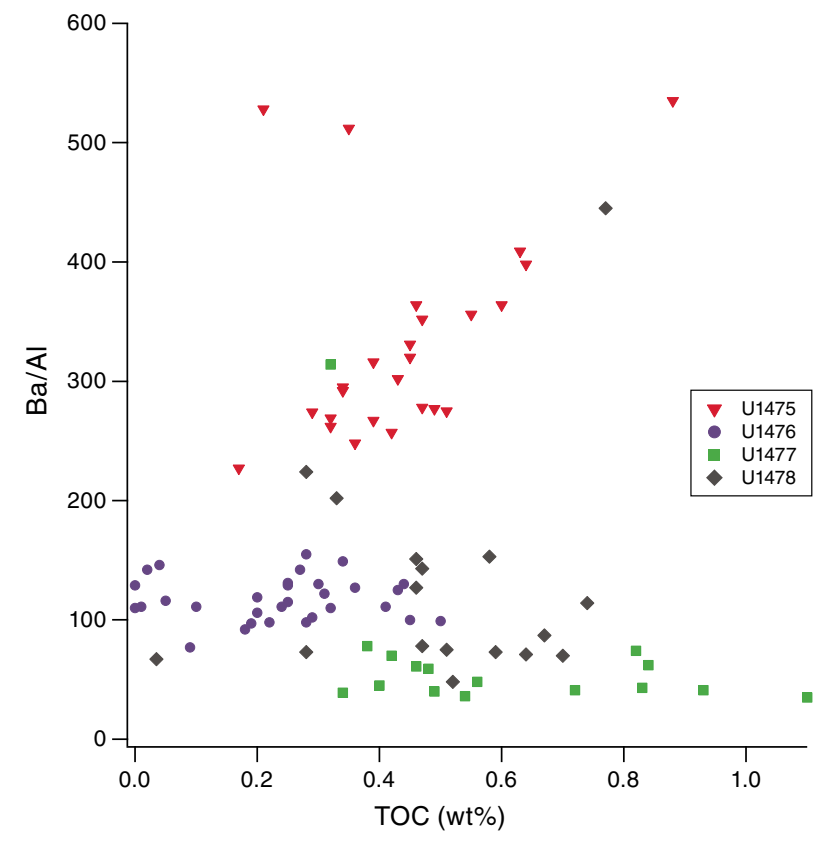

Figure F21. Dissolved sulfate, Sites U1474-U1479.

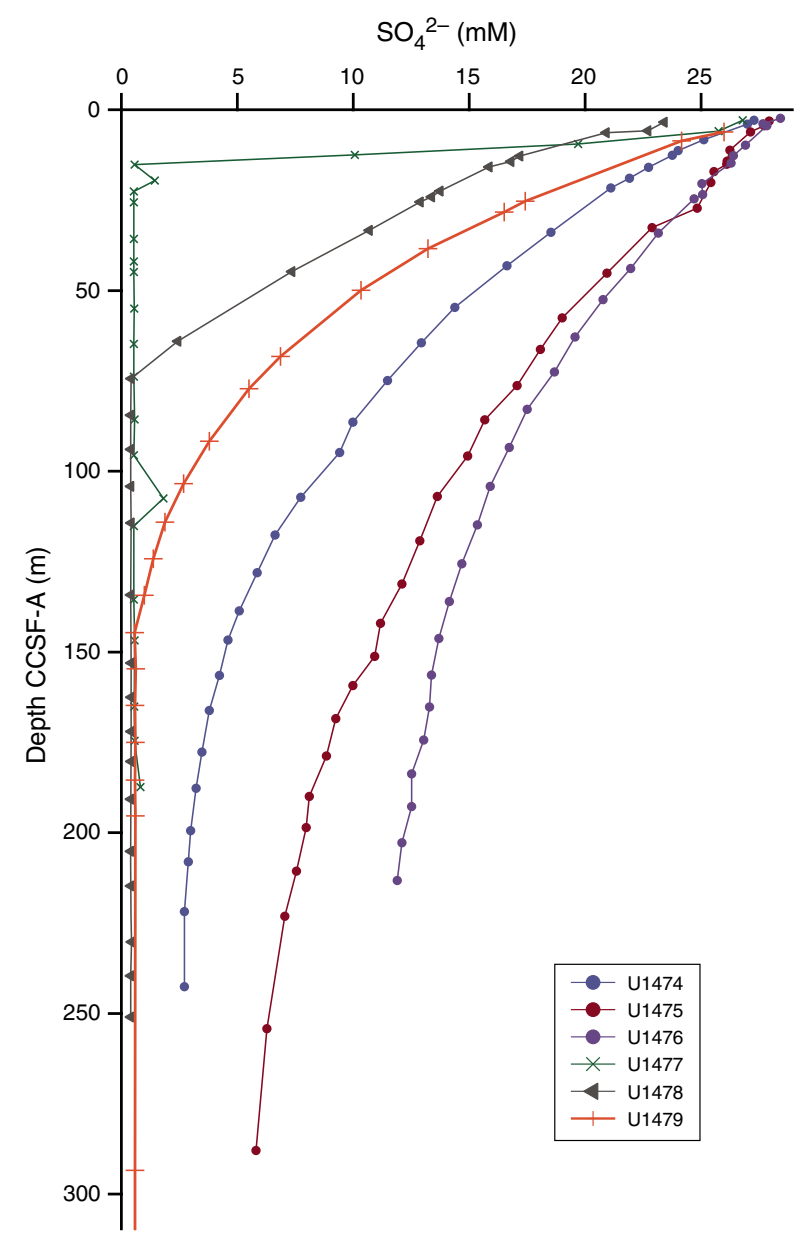


Figure F22. Summary of main shipboard paleomagnetic results (from best paleomagnetic age control [left] to uncertain age-control [right]). Accordingly, the chronologies of Sites U1474, U1475, and U1478 are based on linking the normal and reversed paleomagnetic (sub-)intervals to those of the paleomagnetic stratigraphy of Gradstein at al. (2012). The chronologies of Sites U1476 and U1478 that yield less straightforward paleomagnetic records have been established by utilizing biostratigraphic age-depth tie-points as determined onboard.

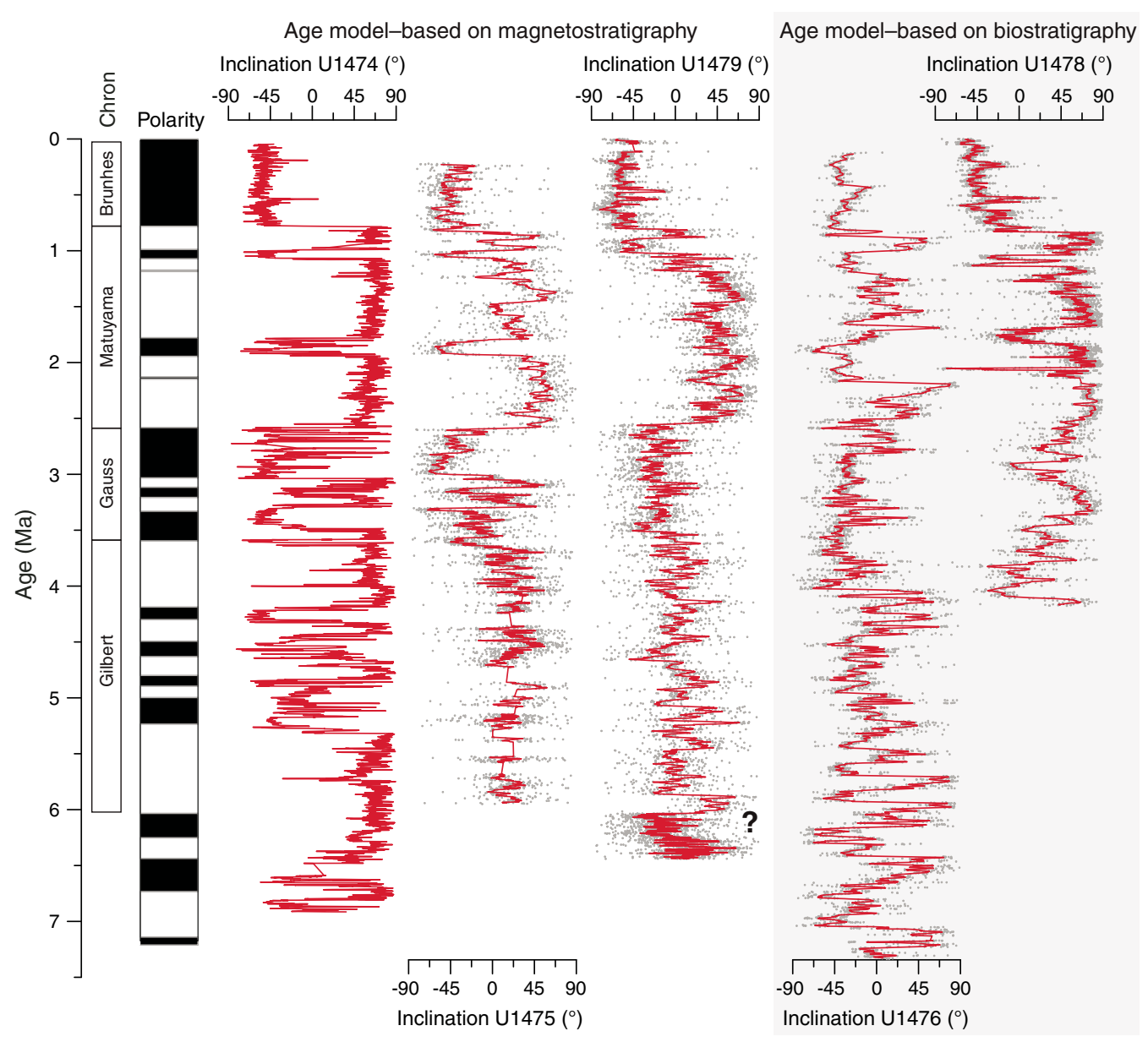

\section{References}

Adkins, J.F., 2013. The role of deep ocean circulation in setting glacial climates. Paleoceanography, 28(3):539-561. http://dx.doi.org/10.1002/palo.20046

Adkins, J.F., McIntyre, K., and Schrag, D.P., 2002. The salinity, temperature, and $\delta^{18} \mathrm{O}$ of the glacial deep ocean. Science, 298(5599):1769-1773. http://dx.doi.org/10.1126/science.1076252

Allen, R.B., and Tucholke, B.E., 1981. Petrography and implications of continental rocks from the Agulhas Plateau, southwest Indian Ocean. Geology, 9(10):463-468. http://dx.doi.org/10.1130/0091-

7613(1981) 9<463:PAIOCR >2.0.CO;2

Arhan, M., Speich, S., Messager, C., Dencausse, G., Fine, R., and Boye, M., 2011. Anticyclonic and cyclonic eddies of subtropical origin in the subantarctic zone south of Africa. Journal of Geophysical Research: Oceans, 116(C11):C11004. http://dx.doi.org/10.1029/2011JC007140

Backeberg, B.C., Penven, P., and Rouault, M., 2012. Impact of intensified Indian Ocean winds on mesoscale variability in the Agulhas system. Nature Climate Change, 2(8):608-612. http://dx.doi.org/10.1038/nclimate1587

Backeberg, B.C., and Reason, C.J.C., 2010. A connection between the South Equatorial Current north of Madagascar and Mozambique Channel eddies. Geophysical Research Letters, 37(4):L04604. http://dx.doi.org/10.1029/2009GL041950
Bard, E., and Rickaby, R.E.M., 2009. Migration of the Subtropical Front as a modulator of glacial climate. Nature, 460(7253):380-383. http://dx.doi.org/10.1038/nature08189

Barker, S., Knorr, G., Edwards, R.L., Parrenin, F., Putnam, A.E., Skinner, L.C., Wolff, E., and Ziegler, M., 2011. 800,000 years of abrupt climate variability. Science, 334(6054):347-351. http://dx.doi.org/10.1126/science.1203580

Bar-Matthews, M., Marean, C.W., Jacobs, Z., Karkanas, P., Fisher, E.C., Herries, A.I.R., Brown, K., Williams, H.M., Bernatchez, J., Ayalon, A., and Nilssen, P.J., 2010. A high resolution and continuous isotopic speleothem record of paleoclimate and paleoenvironment from 90 to 53 ka from Pinnacle Point on the south coast of South Africa. Quaternary Science Reviews, 29(17-18):2131-2145. http://dx.doi.org/10.1016/j.quascirev.2010.05.009

Beal, L.M., and Bryden, H.L., 1999. The velocity and vorticity structure of the Agulhas Current at $32^{\circ} \mathrm{S}$. Journal of Geophysical Research: Oceans, 104(C3):5151-5176. http://dx.doi.org/10.1029/1998JC900056

Beal, L.M., Chereskin, T.K., Lenn, Y.D., and Elipot, S., 2006. The sources and mixing characteristics of the Agulhas Current. Journal of Physical Oceanography, 36(11):2060-2074. http://dx.doi.org/10.1175/JPO2964.1

Beal, L.M., De Ruijter, W.P.M., Biastoch, A., Zahn, R., and SCOR/WCRP/IAPSO Working Group 136, 2011. On the role of the Agulhas system in ocean circulation and climate. Nature, 472(7344):429436. http://dx.doi.org/10.1038/nature09983 
Biastoch, A., Beal, L.M., Lutjeharms, J.R.E., and Casal, T.G.D., 2009a. Variability and coherence of the Agulhas undercurrent in a high-resolution ocean general circulation model. Journal of Physical Oceanography, 39(10):2417-2435. http://dx.doi.org/10.1175/2009JPO4184.1

Biastoch, A., Böning, C.W., and Lutjeharms, J.R.E., 2008. Agulhas leakage dynamics affects decadal variability in Atlantic overturning circulation. Nature, 456(7221):489-492. http://dx.doi.org/10.1038/nature07426

Biastoch, A., Böning, C.W., Schwarzkopf, F.U., and Lutjeharms, J.R.E., 2009b. Increase in Agulhas leakage due to poleward shift of Southern Hemisphere westerlies. Nature, 462(7272):495-498. http://dx.doi.org/10.1038/nature08519

Biastoch, A., and Krauss, W., 1999. The role of mesoscale eddies in the source regions of the Agulhas Current. Journal of Physical Oceanography, 29(9):2303-2317. http://dx.doi.org/10.1175/15200485(1999)029<2303:TROMEI>2.0.CO;2

Broecker, W., and Barker, S., 2007. A $190 \%$ drop in atmosphere's $\Delta^{14} \mathrm{C}$ during the "Mystery Interval" (17.5 to $14.5 \mathrm{kyr}$ ). Earth and Planetary Science Letters, 256(1-2):90-99. http://dx.doi.org/10.1016/j.epsl.2007.01.015

Bryden, H.L., and Beal, L.M., 2001. Role of the Agulhas Current in Indian Ocean circulation and associated heat and freshwater fluxes. Deep Sea Research Part I: Oceanographic Research Papers, 48(8):1821-1845. http://dx.doi.org/10.1016/S0967-0637(00)00111-4

Bryden, H.L., Beal, L.M., and Duncan, L.M., 2005. Structure and transport of the Agulhas Current and its temporal variability. Journal of Oceanography, 61(3):479-492. http://dx.doi.org/10.1007/s10872-005-0057-8

Caley, T., Giraudeau, J., Malaizé, B., Rossignol, L., and Pierre, C., 2012. Agulhas leakage as a key process in the modes of Quaternary climate changes. Proceedings of the National Academy of Sciences of the United States of America, 109(18):6835-6839. http://dx.doi.org/10.1073/pnas.1115545109

Caley, T., Kim, J.-H., Malaizé, B., Giraudeau, J., Laepple, T., Caillon, N., Charlier, K., Rebaubier, H., Rossingol, L., Castañeda, I.S., Schouten, S., and Sinninghe Damsté, J.S., 2011. High-latitude obliquity forcing drives the Agulhas leakage. Climate of the Past Discussions, 7(3):2193-2215. http://dx.doi.org/10.5194/cpd-7-2193-2011

Caley, T., Peeters, F.J.C., Biastoch, A., Rossignol, L., van Sebille, E., Durgadoo, J., Malaizé, B., Giraudeau, J., Arthur, K., and Zahn, R., 2014. Quantitative estimate of the paleo-Agulhas leakage. Geophysical Research Letters, 41(4):1238-1246. http://dx.doi.org/10.1002/2014GL059278

Castañeda, I.S., Caley, T., Dupont, L., Kim, J.-H., Malaizé, B., and Schouten, S., 2016. Middle to Late Pleistocene vegetation and climate change in subtropical southern East Africa. Earth and Planetary Science Letters, 450:306-316. http://dx.doi.org/10.1016/j.epsl.2016.06.049

Castañeda, I.S., Werne, J.P., and Johnson, T.C., 2007. Wet and arid phases in the southeast African tropics since the Last Glacial Maximum. Geology, 35(9):823-826. http://dx.doi.org/10.1130/G23916A.1

Chase, B.M., and Meadows, M.E., 2007. Late Quaternary dynamics of southern Africa's winter rainfall zone. Earth-Science Reviews, 84(3-4):103-38. http://dx.doi.org/10.1016/j.earscirev.2007.06.002

Cheng, H., Edwards, R.L., Broecker, W.S., Denton, G.H., Kong, X., Wang, Y., Zhang, R., and Wang, X., 2009. Ice age terminations. Science, 326(5950):248-252. http://dx.doi.org/10.1126/science.1177840

Collins, J.A. Schefuß, E., Govin, A., Mulitza, S., and Tiedemann, R., 2014. Insolation and glacial-interglacial control on southwestern African hydroclimate over the past 140000 years. Earth and Planetary Science Letters, 398:1-10. http://dx.doi.org/10.1016/j.epsl.2014.04.034

Cunningham, S.A., Kanzow, T., Rayner, D., Baringer, M.O., Johns, W.E., Marotzke, J., Longworth, H.R., Grant, E.M., Hirschi, J.J.-M., Beal, L.M., Meinen, C.S., and Bryden, H.L., 2007. Temporal variability of the Atlantic meridional overturning circulation at $26.5^{\circ} \mathrm{N}$. Science, 317(5840):935-938. http://dx.doi.org/10.1126/science.1141304

De Boer, A.M., Graham, R.M., Thomas, M.D., and Kohfeld, K.E., 2013. The control of the Southern Hemisphere Westerlies on the position of the Subtropical Front. Journal of Geophysical Research: Oceans, 118(10):5669-5675. http://dx.doi.org/10.1002/jgrc.20407

De Ruijter, W., 1982. Asymptotic analysis of the Agulhas and Brazil Current systems. Journal of Physical Oceanography, 12(4):361-373. http://dx.doi.org/10.1175/1520-

0485(1982)012<0361:AAOTAA>2.0.CO;2

de Ruijter, W.P.M., Biastoch, A., Drijfhout, S.S., Lutjeharms, J.R.E., Matano, R.P., Picheven, T., van Leeuwen, P.J., and Weijer, W., 1999a. Indian-Atlantic interocean exchange: dynamics, estimations and impact. Journal of Geophysical Research: Oceans, 104(C9):20885-20910.

http://dx.doi.org/10.1029/1998JC900099

de Ruijter, W.P.M., Ridderinkhof, H., Lutjeharms, J.R.E., Schouten, M.W., and Veth, C., 2002. Observations of the flow in the Mozambique Channel. Geophysical Research Letters, 29(10):140-1-140-3. http://dx.doi.org/10.1029/2001GL013714

de Ruijter, W.P.M., van Leeuwen, P.J., and Lutjeharms, J.R.E., 1999b. Generation and evolution of Natal Pulses: solitary meanders in the Agulhas Current. Journal of Physical Oceangraphy, 29(12):3043-3055. http://dx.doi.org/10.1175/1520-0485(1999)029<3043:GAE$\mathrm{ONP}>2.0 . \mathrm{CO} ; 2$

deMenocal, P.B., Ruddiman, W.F., and Pokras, E.M., 1993. Influences of highand low-latitude processes on African terrestrial climate: Pleistocene eolian records from equatorial Atlantic Ocean Drilling Program Site 663. Paleoceanography, 8(2):209-242. http://dx.doi.org/10.1029/93PA02688

Dickson, A.J., Leng, M.J., Maslin, M.A., Sloane, H.J., Green, J., Bendle, J.A., McClymont, E.L., and Pancost, R.D., 2010. Atlantic overturning circulation and Agulhas leakage influences on southeast Atlantic upper ocean hydrography during marine isotope Stage 11. Paleoceanography, 25(3):PA3208. http://dx.doi.org/10.1029/2009PA001830

Dijkstra, H.A., and de Ruijter, W.P.M., 2001. On the physics of the Agulhas Current: steady retroflection regimes. Journal of Physical Oceanography, 31(10):2971-2985. http://dx.doi.org/10.1175/15200485(2001)031<2971:OTPOTA>2.0.CO;2

Dingle, R.V., Goodlad, S.W., and Martin, A.K., 1978. Bathymetry and stratigraphy of the northern Natal Valley (SW Indian Ocean): a preliminary account. Marine Geology, 28(1-2):89-106. http://dx.doi.org/10.1016/0025-3227(78)90099-3

Donohue, K.A., and Toole, J.M., 2003. A near-synoptic survey of the Southwest Indian Ocean. Deep Sea Research Part II: Topical Studies in Oceanography, 50(12-13):1893-1931. http://dx.doi.org/10.1016/S0967-0645(03)00039-0

Dupont, L.M., Caley, T., Kim, J.-H., Castañeda, I., Malaizé, B., and Giraudeau, J., 2011. Glacial-interglacial vegetation dynamics in south eastern Africa coupled to sea surface temperature variations in the Western Indian Ocean. Climate of the Past, 7(4):1209-1224. http://dx.doi.org/10.5194/cp-7-1209-2011

Dupont, L.M., Donner, B., Vidal, L., Pérez, E.M., and Wefer, G., 2005. Linking desert evolution and coastal upwelling: Pliocene climate change in Namibia. Geology, 33(6):461-464. http://dx.doi.org/10.1130/G21401.1

Durgadoo, J.V., Loveday, B.R., Reason, C.J.C., Penven, P., and Biastoch, A., 2013. Agulhas leakage predominantly responds to the Southern Hemisphere westerlies. Journal of Physical Oceanography, 43(10):2113-2131. http://dx.doi.org/10.1175/JPO-D-13-047.1

Dyez, K.A., Zahn, R., and Hall, I.R., 2014. Multicentennial Agulhas leakage variability and links to North Atlantic climate during the past 80,000years. Paleoceanography, 29(12):1238-1248. http://dx.doi.org/10.1002/2014PA002698

Franzese, A.M., Hemming, S.R., Goldstein, S.L., and Anderson, R.F., 2006. Reduced Agulhas leakage during the Last Glacial Maximum inferred from an integrated provenance and flux study. Earth and Planetary Science Letters, 250(1-2):72-88. http://dx.doi.org/10.1016/j.epsl.2006.07.002

Franzese, A.M., Hemming, S.R., and Goldstein, S.L., 2009. Strontium isotopes in detrital sediments to constrain the glacial position of the Agulhas retroflection. Paleoceanography, 24(2):PA2217. http://dx.doi.org/10.1029/2008PA001706

Gammelsrød, T., 1992. Variation in shrimp abundance on the Sofala Bank, Mozambique, and its relation to the Zambezi River runoff. Estuarine, Coastal and Shelf Science, 35(1):91-103. http://dx.doi.org/10.1016/S0272-7714(05)80058-7 
Gasse, F., and Van Campo, E., 2001. Late Quaternary environmental changes from a pollen and diatom record in the southern tropics (Lake Tritrivakely, Madagascar). Palaeogeography, Palaeoclimatology, Palaeoecology, 167(3-4):287-308. http://dx.doi.org/10.1016/S0031-0182(00)00242-X

Gebbie, G., 2012. Tracer transport timescales and the observed AtlanticPacific lag in the timing of the Last Termination. Paleoceanography, 27(3):PA3225. http://dx.doi.org/10.1029/2011PA002273

Gebbie, G., and Huybers, P., 2006. Meridional circulation during the Last Glacial Maximum explored through a combination of South Atlantic $\delta^{18} \mathrm{O}$ observations and a geostrophic inverse model. Geochemistry, Geophysics, Geosystems, 7(11):Q11N07. http://dx.doi.org/10.1029/2006GC001383

Goddard, L., and Graham, N.E., 1999. Importance of the Indian Ocean for simulating rainfall anomalies over eastern and southern Africa. Journal of Geophysical Research: Atmospheres, 104(D16):19099-19116. http://dx.doi.org/10.1029/1999JD900326

Gong, X., Knorr, G., Lohmann, G., and Zhang, X., 2013. Dependence of abrupt Atlantic meridional ocean circulation changes on climate background states. Geophysical Research Letters, 40(14):3698-3704. http://dx.doi.org/10.1002/grl.50701

Goodlad, S.W., 1986. Tectonic and sedimentary history of the mid-Natal Valley (SW Indian Ocean). Bulletin of Joint Geological Survey/University of Cape Town Marine Geoscience Unit, 15:625-630.

Gordon, A.L., 1985. Indian-Atlantic transfer of thermocline water at the Agulhas retroflection. Science, 227(4690):1030-1033. http://dx.doi.org/10.1126/science.227.4690.1030

Gordon, A.L., 1986. Interocean exchange of thermocline water. Journal of Geophysical Research: Oceans, 91(C4):5037-5046. http://dx.doi.org/10.1029/JC091iC04p05037

Gordon, A.L., 2003. Oceanography: the brawniest retroflection. Nature, 421(6926):904-905. http://dx.doi.org/10.1038/421904a

Gordon, A.L., and Fine, R.A., 1996. Pathways of water between the Pacific and Indian Oceans in the Indonesian seas. Nature, 379(6561):146-149. http://dx.doi.org/10.1038/379146a0

Gordon, A.L., and Haxby, W.F., 1990. Agulhas eddies invade the South Atlantic: evidence from Geosat altimeter and shipboard conductivity-temperature-depth survey. Journal of Geophysical Research: Oceans, 95(C3):3117-3125. http://dx.doi.org/10.1029/JC095iC03p03117

Gordon, A.L., Lutjeharms, J.R.E., and Gründlingh, M.L., 1987. Stratification and circulation at the Agulhas retroflection. Deep-Sea Research, Part A. Oceanographic Research Papers, 34(4):565-599. http://dx.doi.org/10.1016/0198-0149(87)90006-9

Gordon, A.L., Weiss, R.F., Smethie, W.M., Jr., and Warner, M.J., 1992. Thermocline and intermediate water communication between the south Atlantic and Indian Oceans. Journal of Geophysical Research: Oceans, 97(C5):7223-7240. http://dx.doi.org/10.1029/92JC00485

Goschen, W.S., and Schuman, E.H., 1990. Agulhas Current variability and inshore structures off the Cape Province, South Africa. Journal of Geophysical Research: Oceans, 95(C1):667-678. http://dx.doi.org/10.1029/JC095iC01p00667

Gradstein, F.M., Ogg, J.G., Schmitz, M.D., and Ogg, G.M. (Eds.), 2012. The Geological Time Scale 2012: Amsterdam (Elsevier).

Graham, R.M., and De Boer, A.M., 2013. The dynamical Subtropical Front. Journal of Geophysical Research: Oceans, 118(10):5676-5685. http://dx.doi.org/10.1002/jgrc.20408

Haarsma, R.J., Campos, E.J.D., Drijfhout, S., Hazeleger, W., and Severijns, C., 2011. Impacts of interruption of the Agulhas leakage on the tropical Atlantic in coupled ocean-atmosphere simulations. Climate Dynamics, 36(5-6):989-1003. http://dx.doi.org/10.1007/s00382-009-0692-7

Hall, I.R., Hemming, S.R., and LeVay, L.J., 2015. Expedition 361 Scientific Prospectus: South African Climates (Agulhas LGM Density Profile). International Ocean Discovery Program. http://dx.doi.org/10.14379/iodp.sp.361.2015

Harris, T.F.W., 1970. Planetary-type waves in the south west Indian Ocean. Nature, 227(5262):1043-1044. http://dx.doi.org/10.1038/2271043a0

Hopmans, E.C., Weijers, J.W.H., Schefuß, E., Herfort, L., Sinninghe Damsté, J.S., and Schouten, S., 2004. A novel proxy for terrestrial organic matter in sediments based on branched and isoprenoid tetraether lipids. Earth and
Planetary Science Letters, 224(1-2):107-116.

http://dx.doi.org/10.1016/j.epsl.2004.05.012

Hughes, G.O., Hogg, A.M.C., and Griffiths, R.W., 2009. Available potential energy and irreversible mixing in the meridional overturning circulation. Journal of Physical Oceanography, 39(12):3130-3146. http://dx.doi.org/10.1175/2009JPO4162.1

Huguet, C., Smittenberg, R.H., Boer, W., Sinninghe Damsté, J.S., and Schouten, S., 2007. Twentieth century proxy records of temperature and soil organic matter input in the Drammensfjord, southern Norway. Organic Geochemistry, 38(11):1838-1849. http://dx.doi.org/10.1016/j.orggeochem.2007.06.015

Johnson, T.C., Brown, E.T., McManus, J., Barry, S., Barker, P., and Gasse, F., 2002. A high-resolution paleoclimate record spanning the past 25,000 years in southern East Africa. Science, 296(5565):113-132. http://dx.doi.org/10.1126/science.1070057

Johnson, T.C., Werne, J.P., Brown, E.T., Abbott, A., Berke, M., Steinman, B.A., Halbur, J., Contreras, S., Grosshuesch, S., Deino, A., Scholz, C.A., Lyons, R.P., Schouten, S., and Sinninghe Damsté, J.S., 2016. A progressively wetter climate in southern East Africa over the past 1.3 million years. Nature, 537(7619):220-224. http://dx.doi.org/10.1038/nature 19065

Jury, M.R., Valentine, H.R., and Lutjeharms, J.R.E., 1993. Influence of the Agulhas Current on summer rainfall along the southeast coast of South Africa. Journal of Applied Meteorology, 32(7):1282-1287. http://dx.doi.org/10.1175/15200450(1993)032<1282:IOTACO > 2.0.CO;2

Just, J., Schefuß, E., Kuhlmann, H., Stuut, J.-B.W., and Pätzold, J., 2014. Climate induced sub-basin source-area shifts of Zambezi River sediments over the past 17 ka. Palaeogeography, Palaeoclimatology, Palaeoecology, 410:190-199. http://dx.doi.org/10.1016/j.palaeo.2014.05.045

Knor,, G., and Lohmann, G., 2003. Southern Ocean origin for the resumption of Atlantic thermohaline circulation during deglaciation. Nature, 424(6948):532-536. http://dx.doi.org/10.1038/nature01855

Knorr, G., and Lohmann, G., 2007. Rapid transitions in the Atlantic thermohaline circulation triggered by global warming and meltwater during the last deglaciation. Geochemistry, Geophysics, Geosystems, 8(12):Q12006. http://dx.doi.org/10.1029/2007GC001604

Kutzbach, J.E., Liu, X., Liu, Z., and Chen, G., 2008. Simulation of the evolutionary response of global summer monsoons to orbital forcing over the past 280,000 years. Climate Dynamics, 30(6):567-579. http://dx.doi.org/10.1007/s00382-007-0308-z

Lamont, T., Roberts, M.J., Barlow, R.G., and van den Berg, M.A., 2010. Circulation patterns in the Delagoa Bight, Mozambique, and the influence of deep ocean eddies. African Journal of Marine Science, 32(3):553-562. http://dx.doi.org/10.2989/1814232X.2010.538147

LeGrand, P., and Wunsch, C., 1995. Constraints from paleotracer data on the North Atlantic circulation during the Last Glacial Maximum. Paleoceanography, 10(6):1011-1045. http://dx.doi.org/10.1029/95PA01455

Leroux, M., 1983. Le Climat de L'Afrique Tropicale, Atlas (et Texte): Paris (Champion).

Lisiecki, L.E., and Raymo, M.E., 2005. A Pliocene-Pleistocene stack of 57 globally distributed benthic $\delta^{18} \mathrm{O}$ records. Paleoceanography, 20(1):PA1003. http://dx.doi.org/10.1029/2004PA001071

Lund, D.C., Mix, A.C., and Southon, J., 2011. Increased ventilation age of the deep northeast Pacific Ocean during the last deglaciation. Nature Geoscience, 4(11):771-774. http://dx.doi.org/10.1038/ngeo1272

Lutjeharms, J.R.E., 1996. The exchange of water between the South Indian and South Atlantic Oceans. In Wefer, G., Berger, W.H., Siedler, G., and Webb, D.J. (Eds.), The South Atlantic: Present and Past Circulation: Berlin (Springer-Verlag), 125-162.

Lutjeharms, J.R.E., 2006a. The Agulhas Current: Berlin (Springer-Verlag). http://dx.doi.org/10.1007/3-540-37212-1

Lutjeharms, J.R.E., 2006b. The ocean environment off southeastern Africa: a review. South African Journal of Science, 102:419-426. http://reference.sabinet.co.za/webx/access/electronic_journals/sajsci/sajsci_v102_n9_a13.pdf 
Lutjeharms, J.R.E., 2007. Three decades of research on the greater Agulhas Current. Ocean Science, 3(1):129-147. http://dx.doi.org/10.5194/os-3-129-2007

Lutjeharms, J.R.E., and Ansorge, I., 2001. The Agulhas Return Current. Journal of Marine Systems, 30(1-2):115-138. http://dx.doi.org/10.1016/S0924-7963(01)00041-0

Lutjeharms, J.R.E., and de Ruitjer, W.P.M., 1996. The influence of the Agulhas Current on the adjacent coastal zone: possible impacts of climate change. Journal of Marine Systems, 7(2-4):321-336. http://dx.doi.org/10.1016/0924-7963(95)00010-0

Lutjeharms, J.R.E., and Roberts, H.R., 1988. The Natal Pulse: an extreme transient on the Agulhas Current. Journal of Geophysical Research: Oceans, 93(C1):631-645. http://dx.doi.org/10.1029/JC093iC01p00631

Lutjeharms, J.R.E., and Van Ballegooyen, R.C., 1988. The retroflection of the Agulhas Current. Journal of Physical Oceanography, 18(11):1570-1583. http://dx.doi.org/10.1175/15200485(1988)018<1570:TROTAC >2.0.CO;2

Lyons, R.P., Scholz, C.A., Cohen, A.S., King, J.W., Brown, E.T., Ivory, S.J., Johnson, T.C., Deino, A.L., Reinthal, P.N., McGlue, M.M., and Blome, M.W., 2015. Continuous 1.3-million-year record of East African hydroclimate, and implications for patterns of evolution and biodiversity. Proceedings of the National Academy of Sciences of the United States of America, 112(51):15568-15573. http://dx.doi.org/10.1073/pnas.1512864112

Macdonald, A.M., 1993. Property fluxes at $30^{\circ} \mathrm{S}$ and their implications for the Pacific-Indian throughflow and the global heat budget. Journal of Geophysical Research: Oceans, 98(C4):6851-6868. http://dx.doi.org/10.1029/92JC02964

Marchal, O., and Curry, W.B., 2008. On the abyssal circulation in the glacial Atlantic. Journal of Physical Oceanography, 38(9):2014-2037. http://dx.doi.org/10.1175/2008JPO3895.1

Marino, G., Zahn, R., Ziegler, M., Purcell, C., Knorr, G., Hall, I.R., Ziveri, P., and Elderfield, H., 2013. Agulhas salt-leakage oscillations during abrupt climate changes of the Late Pleistocene. Paleoceanography, 28(3):599606. http://dx.doi.org/10.1002/palo.20038

Martínez-Méndez, G., Zahn, R., Hall, I.R., Peeters, F.J.C., Pena, L.D., Cacho, I., and Negre, C., 2010. Contrasting multiproxy reconstructions of surface ocean hydrography in the Agulhas Corridor and implications for the Agulhas leakage during the last 345,000 years. Paleoceanography, 25(4):PA4227. http://dx.doi.org/10.1029/2009PA001879

Maslin, M.A., Pancost, R.D., Wilson, K.E., Lewis, J., and Trauth, M.H., 2012. Three and half million year history of moisture availability of south West Africa: evidence from ODP Site 1085 biomarker records. Palaeogeography, Palaeoclimatology, Palaeoecology, 317-318:41-47. http://dx.doi.org/10.1016/j.palaeo.2011.12.009

Mayaux, P., Bartholomé, E., Fritz, S., and Belward, A., 2004. A new land-cover map of Africa for the year 2000. Journal of Biogeography, 31(6):861-877. http://dx.doi.org/10.1111/j.1365-2699.2004.01073.x

Miller, M.D., Adkins, J.F., Menemenlis, D., and Schodlok, M.P., 2012. The role of ocean cooling in setting glacial southern source bottom water salinity. Paleoceanography, 27(3):PA3207. http://dx.doi.org/10.1029/2012PA002297

Miller, M.D., Simons, M., Adkins, J.F., and Minson, S.E., 2015. The information content of pore fluid $\delta^{18} \mathrm{O}$ and [Cl-]. Journal of Physical Oceanography, 45(8):2070-2094. http://dx.doi.org/10.1175/JPO-D-14-0203.1

Milliman, J.D., and Meade, R.H., 1983. World-wide delivery of river sediment to the oceans. Journal of Geology, 91(1):1-21. http://dx.doi.org/10.1086/628741

Nauw, J.J., van Aken, H.M., Webb, A., Lutjeharms, J.R.E., and de Ruijter, W.P.M., 2008. Observations of the southern East Madagascar Current and undercurrent and countercurrent system. Journal of Geophysical Research: Oceans, 113(C8):C08006. http://dx.doi.org/10.1029/2007JC004639

Otto-Bliesner, B.L., Russell, J.M., Clark, P.U., Liu, Z., Overpeck, J.T., Konecky, B., deMenocal, P., Nicholson, S.E., He, F., and Lu, Z., 2014. Coherent changes of southeastern equatorial and northern African rainfall during the last deglaciation. Science, 346(6214):1223-1227.

http://dx.doi.org/10.1126/science.1259531

Palastanga, V., van Leeuwen, P.J., and de Ruijter, W.P.M., 2006. A link between low-frequency mesoscale eddy variability around Madagascar and the large-scale Indian Ocean variability. Journal of Geophysical Research: Oceans, 111(C9):C09029.

http://dx.doi.org/10.1029/2005JC003081

Parsiegla, N., Gohl, K., and Uenzelmann-Neben, G., 2008. The Agulhas Plateau: structure and evolution of a large igneous province. Geophysical Journal International, 174(1):336-350. http://dx.doi.org/10.1111/j.1365-246X.2008.03808.x

Partridge, T.C., Demenocal, P.B., Lorentz, S.A., Paiker, M.J., and Vogel, J.C., 1997. Orbital forcing of climate over South Africa: a 200,000-year rainfall record from the Pretoria saltpan. Quaternary Science Reviews, 16(10):1125-1133. http://dx.doi.org/10.1016/S0277-3791(97)00005-X

Partridge, T.C., Scott, L., and Schneider, R.R., 2004. Between Agulhas and Benguela: responses of Southern African climates of the Late Pleistocene to current fluxes, orbital precession and the extent of the circum-Antarctic vortex. In Battarbee, R.W., Gasse, F., and Stickley, C.E. (Eds.), Developments in Paleoenvironmental Research (Volume 6): Past Climate Variability through Europe and Africa: Dordrecht, The Netherlands (Springer), 45-68. http://dx.doi.org/10.1007/978-1-4020-2121-3_4

Peeters, F.J.C., Acheson, R., Brummer, G.-J.A., de Ruijter, W.P.M., Schneider, R.R., Ganssen, G.M., Ufkes, E., and Kroon, D., 2004. Vigorous exchange between the Indian and Atlantic Oceans at the end of the past five glacial periods. Nature, 430(7000):661-665.

http://dx.doi.org/10.1038/nature02785

Penven, P., Lutjeharms, J.R.E., and Florenchie, P., 2006. Madagascar: a pacemaker for the Agulhas Current system? Geophysical Research Letters, 33(17):L17609. http://dx.doi.org/10.1029/2006GL026854

Petrick, B.F., McClymont, E.L., Marret, F., and van der Meer, M.T.J., 2015. Changing surface water conditions for the last $500 \mathrm{ka}$ in the southeast Atlantic: implications for variable influences of Agulhas leakage and Benguela upwelling. Paleoceanography, 30(9):1153-1167. http://dx.doi.org/10.1002/2015PA002787

Piotrowski, A.M., Goldstein, S.L., Hemming, S.R., and Fairbanks, R.G., 2004. Intensification and variability of ocean thermohaline circulation through the last deglaciation. Earth and Planetary Science Letters, 225(1-2):205220. http://dx.doi.org/10.1016/j.epsl.2004.06.002

Piotrowski, A.M., Goldstein, S.L., Hemming, S.R., and Fairbanks, R.G., 2005. Temporal relationships of carbon cycling and ocean circulation at glacial boundaries. Science, 307(5717):1933-1938. http://dx.doi.org/10.1126/science.1104883

Quartly, G.D., and Srokosz, M.A., 2004. Eddies in the southern Mozambique Channel. Deep Sea Research Part II: Topical Studies in Oceanography, 51(1-3):69-83. http://dx.doi.org/10.1016/j.dsr2.2003.03.001

Rau, A., Rogers, J., and Chen, M.-T., 2006. Late Quaternary palaeoceanographic record in giant piston cores off South Africa, possibly including evidence of neotectonism. Quaternary International, 148(1):65-77. http://dx.doi.org/10.1016/j.quaint.2005.11.007

Rau, A.J., Rogers, J., Lutjeharms, J.R.E., Giraudeau, J., Lee-Thorp, J.A., Chen, M.-T., and Waelbroeck, C., 2002. A 450-kyr record of hydrological conditions on the western Agulhas Bank slope, south of Africa. Marine Geology, 180(1-4):183-201. http://dx.doi.org/10.1016/S0025-3227(01)00213-4

Reason, C.J.C., 2002. Sensitivity of the southern African circulation to dipole sea-surface temperature patterns in the South Indian Ocean. International Journal of Climatology, 22(4):377-393. http://dx.doi.org/10.1002/joc.744

Reason, C.J.C., Engelbrecht, F., Landman, W.A., Lutjeharms, J.R.E., Piketh, S., Rautenbach, C.J.de W., and Hewitson, B.C., 2006. A review of South African research in atmospheric science and physical oceanography during 2000-2005. South African Journal of Science, 102(1-2):35-45. http://hdl.handle.net/10520/EJC96499

Reason, C.J.C., and Mulenga, H., 1999. Relationships between South African rainfall and SST anomalies in the southwest Indian Ocean. International Journal of Climatology, 19(15):1651-1673. 
http://dx.doi.org/10.1002/(SICI)1097-

0088(199912)19:15<1651::AID-JOC439>3.0.CO;2-U

Richardson, P.L., 2007. Agulhas leakage into the Atlantic estimated with subsurface floats and surface drifters. Deep Sea Research, Part I: Oceanographic Research Papers, 54(8):1361-1389. http://dx.doi.org/10.1016/j.dsr.2007.04.010

Ridderinkhof, H., van der Werf, P.M., Ullgren, J.E., van Aken, H.M., van Leeuwen P.J., and de Ruijter, W.P.M., 2010. Seasonal and interannual variability in the Mozambique Channel from moored current observations. Journal of Geophysical Research: Oceans, 115(C6):C06010. http://dx.doi.org/10.1029/2009JC005619

Ronco, P., Fasolato, G., and Di Silvio, G., 2006. The case of the Zambezi River in Mozambique: some investigations on solid transport phenomena downstream Cahora Bassa Dam. In Alves, E., Cardoso, A., Leal, J., and Ferreira, R. (Eds.), Proceedings of the International Conference on Fluvial Hydraulogy: Lisbon, Portugal (Taylor \& Francis).

Rouault, M.J., and Penven, P., 2011. New perspectives on Natal Pulses from satellite observations. Journal of Geophysical Research: Oceans, 116(C7):C07013. http://dx.doi.org/10.1029/2010JC006866

Rutberg, R.L., Hemming, S.R., and Goldstein, S.L., 2000. Reduced North Atlantic Deep Water flux to the glacial Southern Ocean inferred from neodymium isotope ratios. Nature, 405(6789):935-938. http://dx.doi.org/10.1038/35016049

Schefuß, E., Kuhlmann, H., Mollenhauer, G., Prange, M., and Pätzold, J., 2011. Forcing of wet phases in southeast Africa over the past 17,000 years. Nature, 480(7378):509-512. http://dx.doi.org/10.1038/nature10685

Schefuß, E., Schouten S., Jansen J.H.F., and Sinninghe Damsté, J.S., 2003. African vegetation controlled by tropical sea surface temperatures in the midPleistocene period. Nature, 422(6930):418-421. http://dx.doi.org/10.1038/nature01500

Schefuß, E., Schouten, S., and Schneider, R.R., 2005. Climatic controls on central African hydrology during the past 20,000 years. Nature, 437(7061):1003-1006. http://dx.doi.org/10.1038/nature03945

Schneider, R.R., Price, B., Müller, P.J., Kroon, D., and Alexander, I., 1997. Monsoon related variations in Zaire (Congo) sediment load and influence of fluvial silicate supply on marine productivity in the east equatorial Atlantic during the last 200,000 years. Paleoceanography, 12(3):463-481. http://dx.doi.org/10.1029/96PA03640

Schott, F., Fieux, M., Kindle, J., Swallow, J., and Zantopp, R., 1988. The boundary currents east and north of Madagascar: 2. Direct measurements and model comparisons. Journal of Geophysical Research: Oceans, 93(C5):4963-4974. http://dx.doi.org/10.1029/JC093iC05p04963

Schott, F.A., Xie, S.-P., and McCreary, J.P., Jr., 2009. Indian Ocean circulation and climate variability. Reviews of Geophysics, 47(1):RG1002. http://dx.doi.org/10.1029/2007RG000245

Schouten, M.W., de Ruijter, W.P.M., and van Leeuwen, P.J., 2002a. Upstream control of Agulhas ring shedding. Journal of Geophysical Research: Oceans, 107(C8):23-1-23-11. http://dx.doi.org/10.1029/2001JC000804

Schouten, M.W., de Ruijter, W.P.M., van Leeuwen, P.J., and Dijkstra, H.A., 2002b. An oceanic teleconnection between the equatorial and southern Indian Ocean. Geophysical Research Letters, 29(16):59-1-59-4. http://dx.doi.org/10.1029/2001GL014542

Schouten, M.W., de Ruijter, W.P.M., van Leeuwen, P.J., and Ridderinkhof, H., 2003. Eddies and variability in the Mozambique Channel. Deep Sea Research Part II: Topical Studies in Oceanography, 50(12-13):1987-2003. http://dx.doi.org/10.1016/S0967-0645(03)00042-0

Schrag, D.P., Adkins, J.F., McIntyre, K., Alexander, J.L., Hodell, D.A., Charles, C.D., and McManus, J.F., 2002. The oxygen isotopic composition of seawater during the Last Glacial Maximum. Quaternary Science Reviews, 21(1-3):331-342. http://dx.doi.org/10.1016/S0277-3791(01)00110-X

Schrag, D.P., and DePaolo, D.J., 1993. Determination of $\delta^{18} \mathrm{O}$ of seawater in the deep ocean during the Last Glacial Maximum. Paleoceanography, 8(1):16. http://dx.doi.org/10.1029/92PA02796

Schrag, D.P., Hampt, G., and Murray, D.W., 1996. Pore fluid constraints on the temperature and oxygen isotopic composition of the glacial ocean. Sci- ence, 272(5270):1930-1932.

http://dx.doi.org/10.1126/science.272.5270.1930

Schulz, H., Lückge, A., Emeis, K.-C., and Mackensen, A., 2011. Variability of Holocene to Late Pleistocene Zambezi riverine sedimentation at the upper continental slope off Mozambique, $15^{\circ}-21^{\circ} \mathrm{S}$. Marine Geology, 286(1-4):21-34. http://dx.doi.org/10.1016/j.margeo.2011.05.003

Scott, L., Holmgren, K., and Partridge, T.C., 2008. Reconciliation of vegetation and climatic interpretations of pollen profiles and other regional records from the last 60 thousand years in the Savanna Biome of southern Africa. Palaeogeography, Palaeoclimatology, Palaeoecology, 257(1-2):198-206. http://dx.doi.org/10.1016/j.palaeo.2007.10.018

Sijp, W.P., and England, M.H., 2008. The effect of a northward shift in the Southern Hemisphere westerlies on the global ocean. Progress in Oceanography, 79(1):1-19. http://dx.doi.org/10.1016/j.pocean.2008.07.002

Simon, M.H., Arthur, K.L, Hall, I.R, Peeters, F.J.C., Loveday, B.R., Barker, S., Ziegler, M., and Zahn, R., 2013. Millennial-scale Agulhas Current variability and its implications for salt-leakage through the Indian-Atlantic ocean gateway. Earth and Planetary Science Letters, 383:101-112. http://dx.doi.org/10.1016/j.epsl.2013.09.035

Simon, M.H., Gong, X., Hall, I.R., Ziegler, M., Barker, S., Knorr, G., van der Meer, M.T.J., Kasper, S., and Schouten, S., 2015a. Salt exchange in the Indian-Atlantic ocean gateway since the Last Glacial Maximum: a compensating effect between Agulhas Current changes and salinity variations? Paleoceanography, 30(10):1318-1327. http://dx.doi.org/10.1002/2015PA002842

Simon, M.H., Ziegler, M., Bosmans, J., Barker, S., Reason, C.J.C., and Hall, I.R., 2015b. Eastern South African hydroclimate over the past 270,000 years. Scientific Reports, 5:18153. http://dx.doi.org/10.1038/srep18153

Simpson, E.S.W., Schlich, R., et al., 1974. Initial Reports of the Deep Sea Drilling Project, 25: Washington, DC (U.S. Government Printing Office). http://dx.doi.org/10.2973/dsdp.proc.25.1974

Singleton, A.T., and Reason, C.J.C., 2007. A numerical model study of an intense cutoff low pressure system over South Africa. Monthly Weather Review, 135:1128-1150. http://dx.doi.org/10.1175/MWR3311.1

Song, Q., Gordon, A.L., and Visbeck, M., 2004. Spreading of the Indonesian Throughflow in the Indian Ocean. Journal of Physical Oceanography, 34(4):772-792. http://dx.doi.org/10.1175/15200485(2004)034<0772:SOTITI >2.0.CO;2

Speich, S., Blanke, B., de Vries, P., Drijfhout, S., Döös, K., Ganachaud, A., and Marsh, R., 2002. Tasman leakage: a new route in the global ocean conveyor belt. Geophysical Research Letters, 29(10):55-1-55-4. http://dx.doi.org/10.1029/2001GL014586

Stokes, S., Washington, R., and Preston, A., 1999. Late Quaternary evolution of the central Southern Kalahari: environmental responses to changing climatic conditions. In Andrews, P., and Banham, P. (Eds.), Late Cenozoic Environments and Hominid Evolution: a Tribute to Bill Bishop: Bath, United Kingdom (The Geological Society Publishing House), 247-268.

Stramma, L., and Lutjeharms, J.R.E., 1997. The flow field of the subtropical gyre of the South Indian Ocean. Journal of Geophysical Research: Oceans, 102(C3):5513-5530. http://dx.doi.org/10.1029/96JC03455

Stuut, J.-B.W., Prins, M.A., Schneider, R.R., Weltje, G.J., Jansen, F.J.H., and Postma, G., 2002. A 300-kyr record of aridity and wind strength in southwestern Africa: inferences from grain-size distributions of sediments on Walvis Ridge, SE Atlantic. Marine Geology, 180(1-4):221-233. http://dx.doi.org/10.1016/S0025-3227(01)00215-8

Takahashi, T., Sutherland, S.C., Wanninkhof, R., Sweeney, C., Feely, R.A., Chipman, D.W., Hales, B., Friederich, G., Chavez, F., Sabine, C., Watson, A., Bakker, D.C.E., Schuster, U., Metzl, N., Yoshikawa-Inoue, H., Ishii, M., Midorikawa, T., Nojiri, Y., Körtzinger, A., Steinhoff, T., Hoppema, M., Olafsson, J., Arnarson, T.S., Tilbrook, B., Johannessen, T., Olsen, A., Bellerby, R., Wong, C.S., Delille, B., Bates, N.R., and de Baar, H.J.W., 2009. Climatological mean and decadal changes in surface ocean $p \mathrm{CO}_{2}$, and net sea-air $\mathrm{CO}_{2}$ flux over the global oceans. Deep Sea Research, Part II: Topical Studies in Oceanography, 56(8-10):554-577. http://dx.doi.org/10.1016/j.dsr2.2008.12.009 
Ternon, J.F., Bach, P., Barlow, R., Huggett, J., Jaquemet, S., Marsac, F., Ménard, F., Penven, P., Potier, M., and Roberts, M.J., 2014. The Mozambique Channel: from physics to upper trophic levels. Deep Sea Research Part II: Topical Studies in Oceanography, 100:1-9. http://dx.doi.org/10.1016/j.dsr2.2013.10.012

Thomas, D.S.G., O'Connor, P.W., Bateman, M.D., Shaw, P.A., Stokes, S., and Nash, D.J., 2000. Dune activity as a record of late Quaternary aridity in the northern Kalahari: new evidence from northern Namibia interpreted in the context of regional arid and humid chronologies. Palaeogeography, Palaeoclimatology, Palaeoecology, 156(3-4):243-259. http://dx.doi.org/10.1016/S0031-0182(99)00143-1

Tierney, J.E., Russell, J.M., Huang, Y., Sinninghe Damsté, J.S., Hopmans, E.C., and Cohen, A.S., 2008. Northern Hemisphere controls on tropical southeast African climate during the past 60,000 years. Science, 322(5899):252255. http://dx.doi.org/10.1126/science.1160485

Tierney, J.E., Russell, J.M., Sinninghe Damsté, J.S., Huang, Y., and Verschuren, D., 2011. Late Quaternary behavior of the East African monsoon and the importance of the Congo Air Boundary. Quaternary Science Reviews, 30(7-8):798-807.

http://dx.doi.org/10.1016/j.quascirev.2011.01.017

Toggweiler, J.R., and Samuels, B., 1995. Effect of Drake Passage on the global thermohaline circulation. Deep Sea Research, Part I, 42(4):477-500. http://dx.doi.org/10.1016/0967-0637(95)00012-U

Tsugawa, M., and Hasumi, H., 2010. Generation and growth mechanism of the Natal Pulse. Journal of Physical Oceanography, 40(7):1597-1612. http://dx.doi.org/10.1175/2010JPO4347.1

Tuenter, E., Weber, S.L., Hilgen, F.J., and Lourens, L.J., 2003. The response of the African summer monsoon to remote and local forcing due to precession and obliquity. Global and Planetary Change, 36(4):219-235. http://dx.doi.org/10.1016/S0921-8181(02)00196-0

Tyson, P.D., 1986. Climatic Change and Variability in Southern Africa: Oxford, United Kingdom (Oxford University Press).

Uenzelmann-Neben, G., 1998. Sedimentation and tectonics of Agulhas Ridge and Agulhas Plateau. Berichte zur Polar und Meeresforschung, 273:22.

Uenzelmann-Neben, G., 2001. Seismic characteristics of sediment drifts: an example from the Agulhas Plateau, southwest Indian Ocean. Marine Geophysical Research, 22(5):323-343. http://dx.doi.org/10.1023/A:1016391314547

Uenzelmann-Neben, G., 2002. Contourites on the Agulhas Plateau, SW Indian Ocean: indications for the evolution of currents since Palaeogene times. In Stow, D.A.V., Pudsey, C.J., Howe, J.A., Faugères, J.-C., and Viana, A.R. (Eds.), Deep-Water Contourite Systems: Modern Drifts and Ancient Series, Seismic and Sedimentary Characteristics. Memoirs - Geological Society of London, 22(1):271-288. http://dx.doi.org/10.1144/GSL.MEM.2002.022.01.20

Ullgren, J.E., van Aken, H.M., Ridderinkhof, H., and de Ruijter, W.P.M., 2012. The hydrography of the Mozambique Channel from six years of continuous temperature, salinity, and velocity observations. Deep Sea Research Part I: Oceanographic Research Papers, 69:36-50. http://dx.doi.org/10.1016/j.dsr.2012.07.003

van der Lubbe, H.J.L., Frank, M., Tjallingii, R., and Schneider, R.R., 2016. Neodymium isotope constraints on provenance, dispersal, and climate-driven supply of Zambezi sediments along the Mozambique margin during the past 45,000 years. Geochemistry, Geophysics, Geosystems, 17(1):181198. http://dx.doi.org/10.1002/2015GC006080

van der Lubbe, H.J.L., Tjallingii, R., Prins, M.A., Brummer, G.-J.A., Jung, S.J.A., Kroon, D., and Schneider, R.R., 2014. Sedimentation patterns off the Zambezi River over the last 20,000 years. Marine Geology, 355:189201. http://dx.doi.org/10.1016/j.margeo.2014.05.012

van Leeuwen, P.J., de Ruijter, W.P.M., and Lutjeharms, J.R.E., 2000. Natal Pulses and the formation of Agulhas rings. Journal of Geophysical Research: Oceans, 105(C3):6425-6436. http://dx.doi.org/10.1029/1999JC900196

van Sebille, E., Biastoch, A., van Leeuwen, P.J., and de Ruijter, W.P.M., 2009. A weaker Agulhas Current leads to more Agulhas leakage. Geophysical Research Letters, 36(3). http://dx.doi.org/10.1029/2008GL036614 van Sebille, E., and van Leeuwen, P.J., 2007. Fast northward energy transfer in the Atlantic due to Agulhas rings. Journal of Physical Oceanography, 37(9):2305-2315. http://dx.doi.org/10.1175/JPO3108.1

van Sebille, E., van Leeuwen, P.J., Biastoch, A., and de Ruijter, W.P.M., 2010. On the fast decay of Agulhas rings. Journal of Geophysical Research: Oceans, 115(C3):C03010. http://dx.doi.org/10.1029/2009JC005585

Visbeck, M., 2007. Oceanography: power of pull. Nature, 447(7143):383. http://dx.doi.org/10.1038/447383a

Walford, H.L., White, N.J., and Sydow, J.C., 2005. Solid sediment load history of the Zambezi Delta. Earth and Planetary Science Letters, 238(1-2):4963. http://dx.doi.org/10.1016/j.epsl.2005.07.014

Walker, N.D., 1990. Links between South African summer rainfall and temperature variability of the Agulhas and Benguela Current systems. Journal of Geophysical Research: Oceans, 95(C3):3297-3319. http://dx.doi.org/10.1029/JC095iC03p03297

Wang, Y., Cheng, H., Edwards, R.L., Kong, X., Shao, X., Chen, S., Wu, J., Jiang, X., Wang, X., and An, Z., 2008. Millennial- and orbital-scale changes in the East Asian monsoon over the past 224,000 years. Nature, 451(7182):1090-1093. http://dx.doi.org/10.1038/nature06692

Wang, Y.J., Cheng, H., Edwards, R.L., An, Z.S., Wu, J.Y., Shen, C.-C., and Dorale, J.A., 2001. A high-resolution absolute-dated late Pleistocene monsoon record from Hulu Cave, China. Science, 294(5580):2345-2348. http://dx.doi.org/10.1126/science.1064618

Wang, Y.V., Larsen, T., Leduc, G., Andersen, N., Blanz, T., and Schneider, R.R., 2013. What does leaf wax $\delta \mathrm{D}$ from a mixed $\mathrm{C}_{3} / \mathrm{C}_{4}$-vegetation region tell us? Geochimica et Cosmochimica Acta, 111:128-139. http://dx.doi.org/10.1016/j.gca.2012.10.016

Watson, A.J., and Garabato, A.C.N., 2006. The role of Southern Ocean mixing and upwelling in glacial-interglacial atmospheric $\mathrm{CO}_{2}$ change. Tellus, Series B, 58(1):73-87. http://dx.doi.org/10.1111/j.1600-0889.2005.00167.x

Weber, S.L., and Tuenter, E., 2011. The impact of varying ice sheets and greenhouse gases on the intensity and timing of boreal summer monsoons. Quaternary Science Reviews, 30(3-4):469-479. http://dx.doi.org/10.1016/j.quascirev.2010.12.009

Weijer, W., 2001. Impact of interocean exchange on the Atlantic overturning circulation [Ph.D. thesis]. Universiteit Utrecht, Germany. http://dspace.library.uu.nl/handle/1874/529

Weijer, W., de Ruijter, W.P.M., Dijkstra, H.A., and van Leeuwen, P.J., 1999. Impact of interbasin exchange on the Atlantic overturning circulation. Journal of Physical Oceanography, 29(9):2266-2284. http://dx.doi.org/10.1175/15200485(1999)029<2266:IOIEOT > 2.0.CO;2

Weijer, W., De Ruijter, W.P.M., Sterl, A., and Drijfhout, S.S., 2002. Response of the Atlantic overturning circulation to South Atlantic sources of buoyancy. Global and Planetary Change, 34(3-4):293-311. http://dx.doi.org/10.1016/S0921-8181(02)00121-2

Weldeab, S., Lea, D.W., Oberhänsli, H., and Schneider, R.R., 2014. Links between southwestern tropical Indian Ocean SST and precipitation over southeastern Africa over the last $17 \mathrm{kyr}$. Palaeogeography, Palaeoclimatology, Palaeoecology, 410:200-212. http://dx.doi.org/10.1016/j.palaeo.2014.06.001

Weldeab, S., Lea, D.W., Schneider, R.R., and Andersen, N., 2007. 155,000 years of West African monsoon and ocean thermal evolution. Science, 316(5829):1303-1307. http://dx.doi.org/10.1126/science.1140461

Weldeab, S., Stuut, J.-B.W., Schneider, R.R., and Siebel, W., 2013. Holocene climate variability in the winter rainfall zone of South Africa. Climate of the Past, 9(5):2347-2364. http://dx.doi.org/10.5194/cp-9-2347-2013

Ziegler, M., Simon, M.H., Hall, I.R., Barker, S., Stringer, C., and Zahn, R., 2013. Development of Middle Stone Age innovation linked to rapid climate change. Nature Communications, 4:1905. http://dx.doi.org/10.1038/ncomms2897

Ziegler, M., Tuenter, E., and Lourens, L.J., 2010. The precession phase of the boreal summer monsoon as viewed from the eastern Mediterranean (ODP Site 968). Quaternary Science Reviews, 29(11-12):1481-1490. http://dx.doi.org/10.1016/j.quascirev.2010.03.011 